
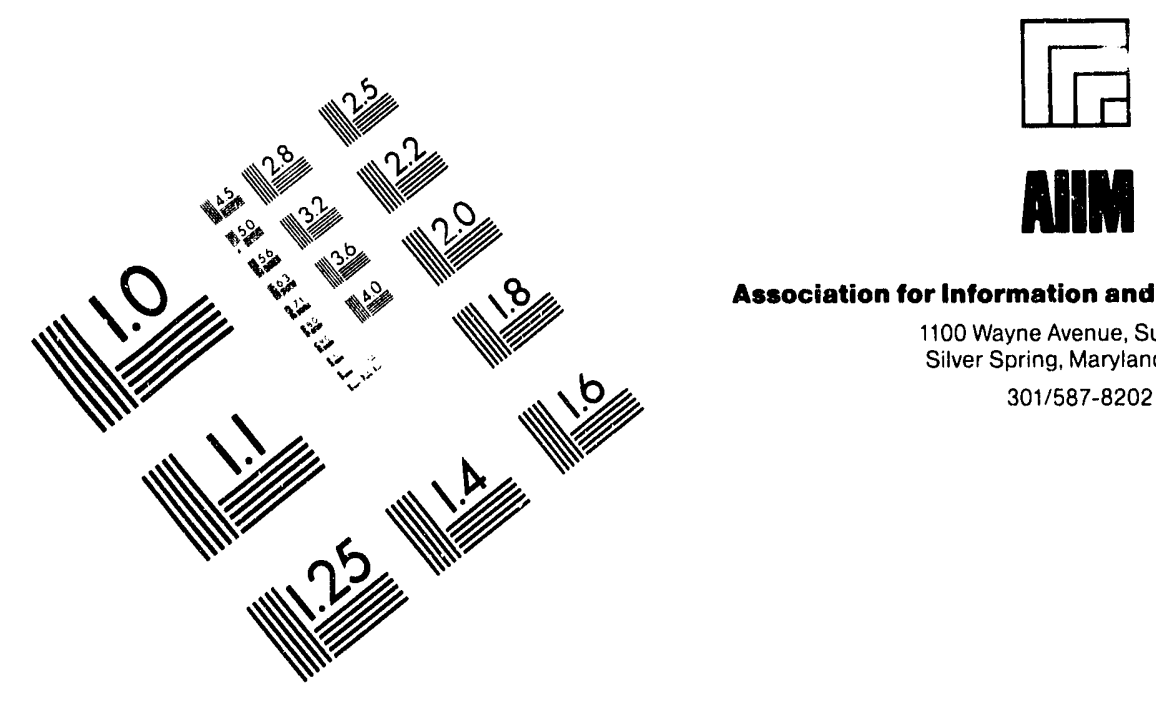

Association for Information and Image Management

1100 Wayne Avenue, Suite 1100

Silver Spring, Maryland 20910

301/587-8202

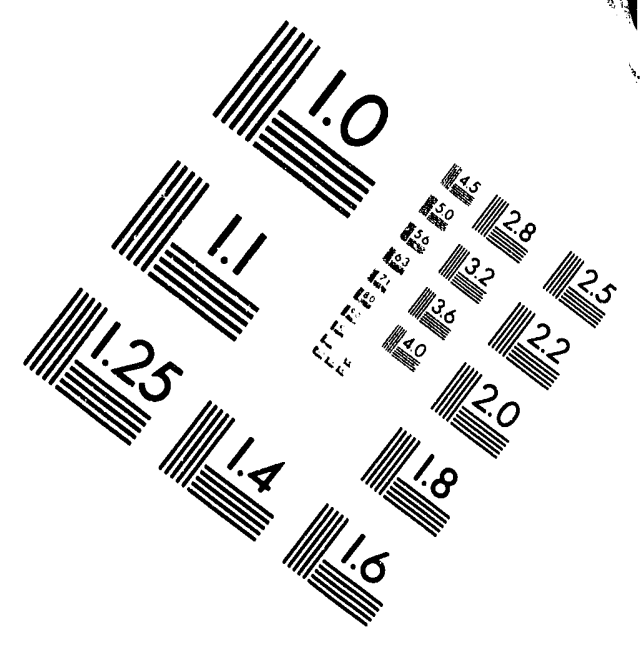

Centimeter

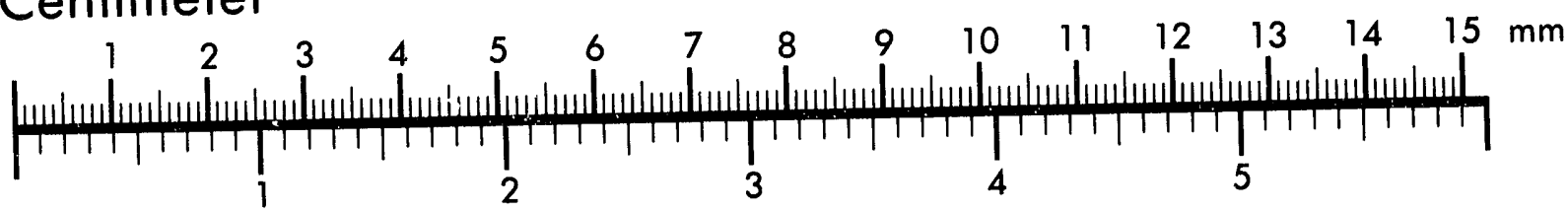

Inches
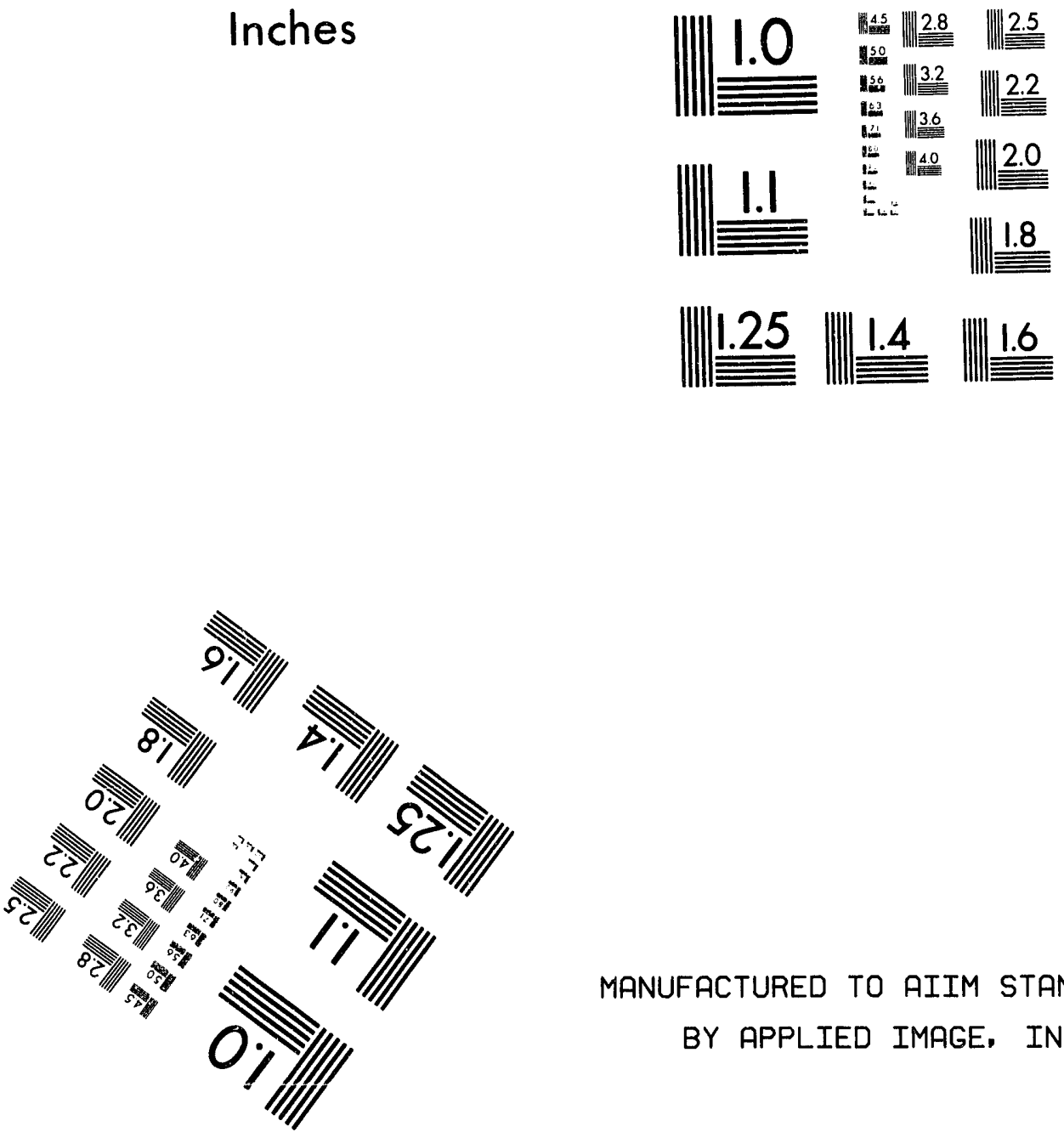

MANUFACTURED TO AIIM STANDARDS

BY APPLIED IMAGE, INC.

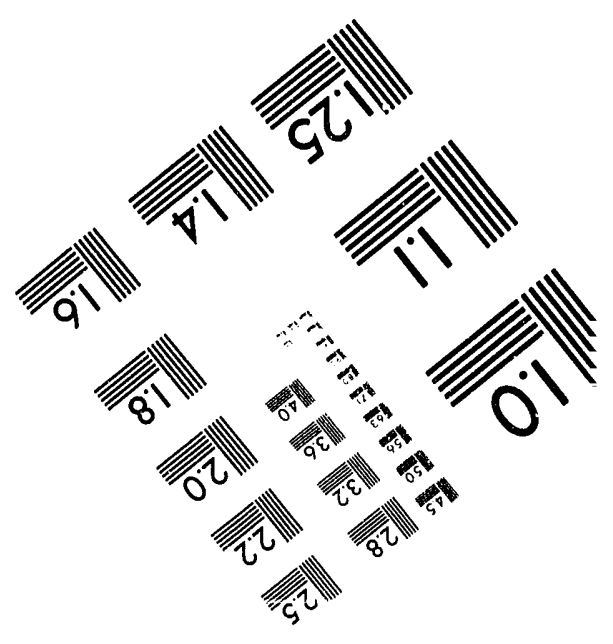



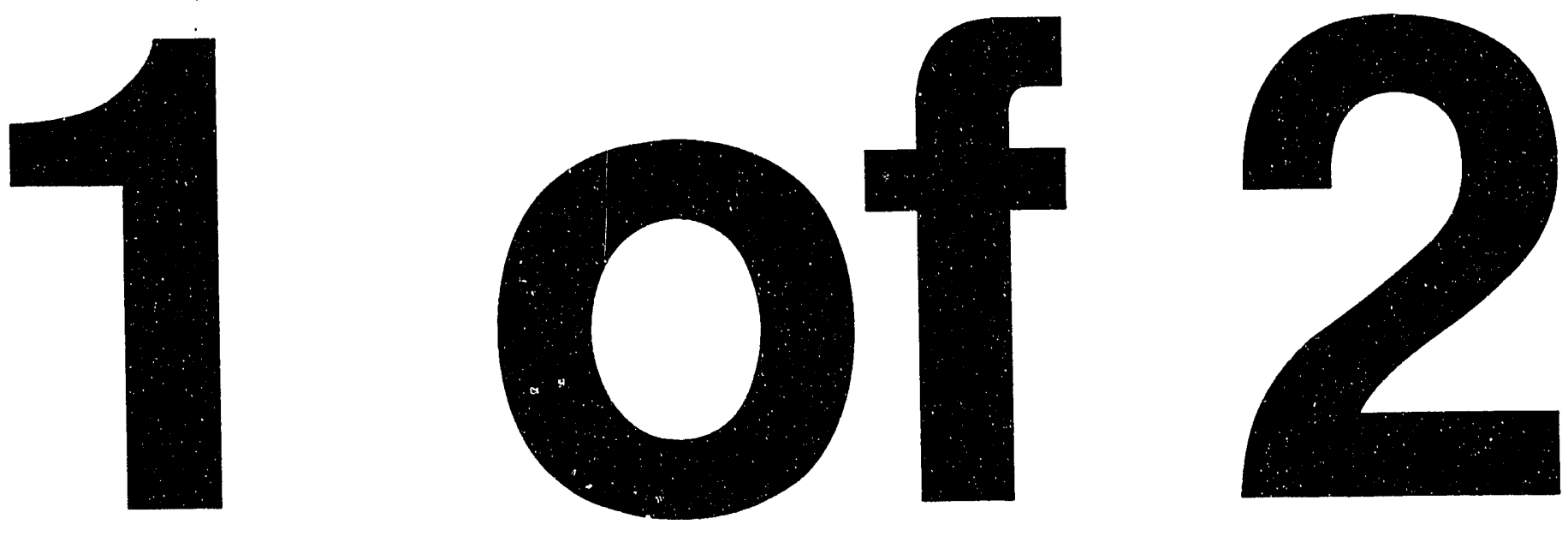
LBL-33741

UC-000

\title{
PROSPECTS FOR THE POWER SECTOR IN NINE DEVELOPING COUNTRIES
}

Stephen Meyers, Nina Goldman, Nathan Martin, and Rafael Friedmann

\author{
Energy Analysis Program \\ Energy and Environment Division \\ Lawrence Berkeley Laboratory \\ University of California \\ Berkeley, CA 94720
}

April 1993

This work was supported by the Office of Environmental Policy Analysis of the U.S. Department of Energy through the U.S. Department of Encrgy Contract No. DE-AC03-76SF00098. 


\begin{abstract}
Based on information drawn primarily from official planning documents issued by national governments and/or utilities, we examined the outlook for the power sector in the year 2000 in nine countries: China, India, Indonesia, Thailand, the Philippines, South Korea, Taiwan, Argentina and Mexico. We found that the implicit rates of average annual growth of installed electric power capacity between 1991 and 2001 range from a low of 3.3\% per year in Argentina to a high of $13.2 \%$ per year in Indonesia. In absolute terms, China and India account for the vast majority of the growth. The plans call for a shift in the generating mix towards coal in six of the countries, and continued strong reliance on coal in China and India. The use of natural gas is expected to increase substantially in a number of the countries. The historic movement away from oil continues, although some countries are maintaining dual-fuel capabilities. Plans call for considerable growth of nuclear power in South Korea and China and modest increases in India and Taiwan. The feasibility of the official plans varies among the countries. Lack of public capital is leading towards greater reliance on private sector participation in power projects in many of the countries. Environmental issues are becoming a more significant constraint than in the past, particularly in the case of large-scale hydropower projects. The financial and environmental constraints are leading to a rising interest in methods of improving the efficiency of electricity supply and end use. The scale of such activities is growing in most of the study countries.
\end{abstract}




\section{Acknowledgements}

This work was supported by the Office of Environmental Policy Analysis of the U.S. Department of Energy. The authors are grateful for the helpful comments of Jayant Sathaye and John Busch, Lawrence Berkeley Laboratory, Curtis Felix, Energy Research Group, and S. Padmanabhan, RCG/Hagler, Bailly, Inc. 


\section{TABLE OF CONTENTS}

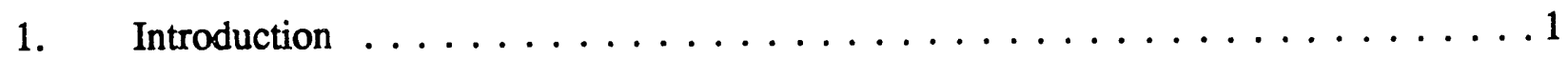

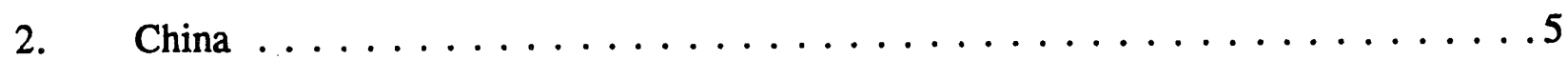

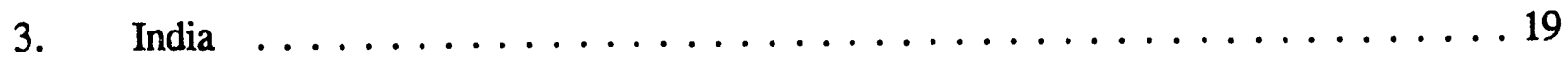

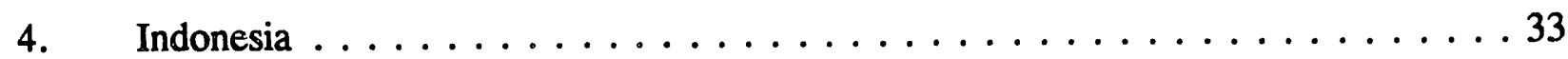

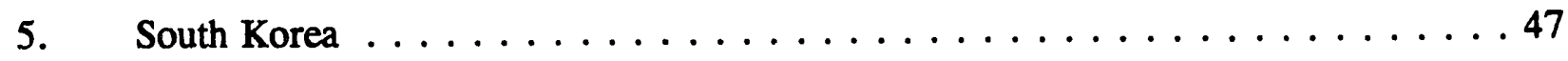

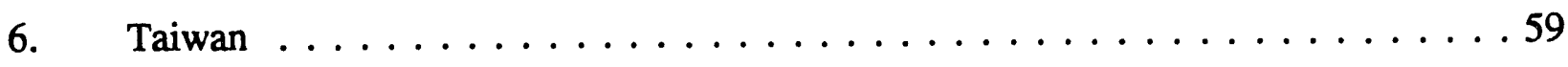

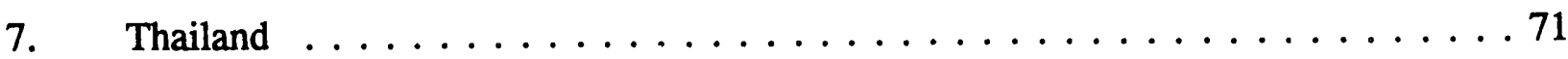

8. Philippines $\ldots \ldots \ldots \ldots \ldots \ldots \ldots \ldots \ldots \ldots \ldots \ldots \ldots \ldots \ldots \ldots$

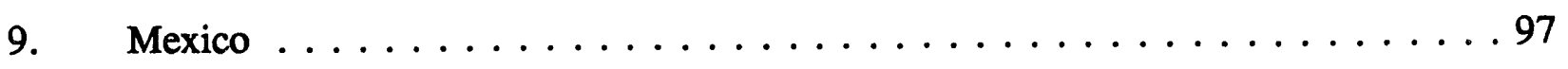

10. Argentina $\ldots \ldots \ldots \ldots \ldots \ldots \ldots \ldots \ldots \ldots \ldots \ldots \ldots \ldots \ldots \ldots$

11. Summary and Conclusion $\ldots \ldots \ldots \ldots \ldots \ldots \ldots \ldots \ldots \ldots \ldots$ 


\section{INTRODUCTION}

The past decade has witnessed considerable growth in electricity consumption in developing countries (LDCs). Developing countries still account for a small portion of world electricity demand (about $22 \%$ in 1990), and electricity generation per capita in LDCs, at 0.66 $\mathrm{MWh}$, stands well below the $8.2 \mathrm{MWh}$ per capita average in the countries of the Organization for Economic Cooperation and Development (OECD). ${ }^{1}$ Increasingly, however, the power sector has come to comprise a significant share of developing world energy use and of the growth in world energy demand.

A Lawrence Berkeley Laboratory (LBL) study published in 1989 described the power sector trends in 13 developing countries and provided a picture of long-term electricity generation and capacity based on official plans issued by national utilities and governments. ${ }^{2}$ This report updates the 1989 study in light of the considerable changes that have occurred in the power sector in these countries over the past few years.

Electricity demand has risen faster than expected in much of Asia. In Latin America, the wave of economic reforms has enhanced the prospects for more rapid growth of electricity demand than was previously projected. At the same time that demand is rising, electric utilities and governments face serious constraints on their ability to expand generating capacity fast enough to keep pace. In a number of countries in Asia, including China and India, shortages already are a major problem.

Some of the constraints to expanding the power base are financial and institutional, the residue of years of poor management, political interference, and accumulating debt. The expansion of electricity-generating capacity also requires high investment outlays. Combined with the ubiquitous shortage of capital in most developing countries, the more conservative lending environment of the 1990s poses a major hurdle. The financial problems of the power sector are leading to growing interest in private sector participation, which has considerable potential but presents new regulatory challenges.

Environmental and social factors also increasingly are influencing plans for the power sector in developing countries. Domestic opposition to high-impact power facilities has caused project delays and even cancellations in a number of countries. In particular, environmental concerns have affected plans to develop indigenous hydroelectric resources, which traditionally have provided a major source of power in many developing countries. While developing countries are not expected to give the same degree of attention to limiting carbon dioxide emissions as the industrialized countries, the rising contribution of the developing world power

\footnotetext{
${ }^{1}$ Meyers, S. and C. Campbell, Trends in Electricity Demand and Supply in the Developing Countries, 1980-1990, LBL33166, Lawrence Berkeley Laboratory, Berkeley, CA, November 1992.

${ }^{2}$ Meyers, S. et al., Plans for the Power Sector in 13 Major Developing Countries, LBL-27764, Lawrence Berkeley Laboratory, Berkeley, CA, October 1989.
} 
sector to global emissions may lead to increased levels of assistance to restrain such growth.

This report describes the prospects for the power sector over the next decade in nine countries: China, India, Indonesia, South Korea, Taiwan, Thailand, the Philippines, Mexico and Argentina. ${ }^{3}$ Together, these countries account for some $55 \%$ of total electricity generation in the developing world. In particular, this study focuses on those countries where fossil fuels play a major role in the power sector. The nine countries included in this report account for the vast majority of electricity generated from fossil fuels in the developing world. ${ }^{4}$

Table 1-1 provides background information on the study countries. In the 1980s, electricity generation growth rates ranged from a low of $2.8 \%$ year in Argentina to a high of 15\%/year in Indonesia. Electricity generation per capita in 1990 was far higher in Taiwan and South Korea than in the other countries.

The nine country studies that follow describe the most recent demand forecasts and official plans for the power sector, prospects for private sector participation, financial issues and key environmental factors. This information was drawn primarily from official government documents, all of which are cited in the individual chapters. The country studies also discuss the potential for improving the efficiency of electricity supply and use, and identify end-use efficiency policies and programs that have been implemented in some of the countries. The final chapter provides a summary of the country studies.

Note on authorship of sections: Nina Goldman wrote the sections on Indonesia, South Korea, Taiwan, Thailand and Argentina (the latter was based on material prepared by Gautum Dutt, consultant). Nathan Martin wrote the sections on China, India and the Philippines. Rafael Friedmann wrote the section on Mexico. Stephen Meyers provided overall guidance, wrote the concluding chapter and contributed to each of the country chapters. In addition, Jayant Sathaye supervised the overall project and contributed to the section on India. Charles Campbell produced the graphics for the report.

\footnotetext{
${ }^{3}$ South Korea and Taiwan are considered to be "newly industrialized countries" falling somewhere between the "developing" and traditional "industrialized" countries. This report includes South Korea and Taiwan under the umbrella of developing countries, but one should be aware that their situation is rather different from that of the other countries.

${ }^{4}$ Four countries included in the 1989 report were not included in this study. We have not covered Brazil and Venezuela, countries which rely heavily on hydropower, or Pakistan and Malaysia, for which we could not obtain current information.
} 


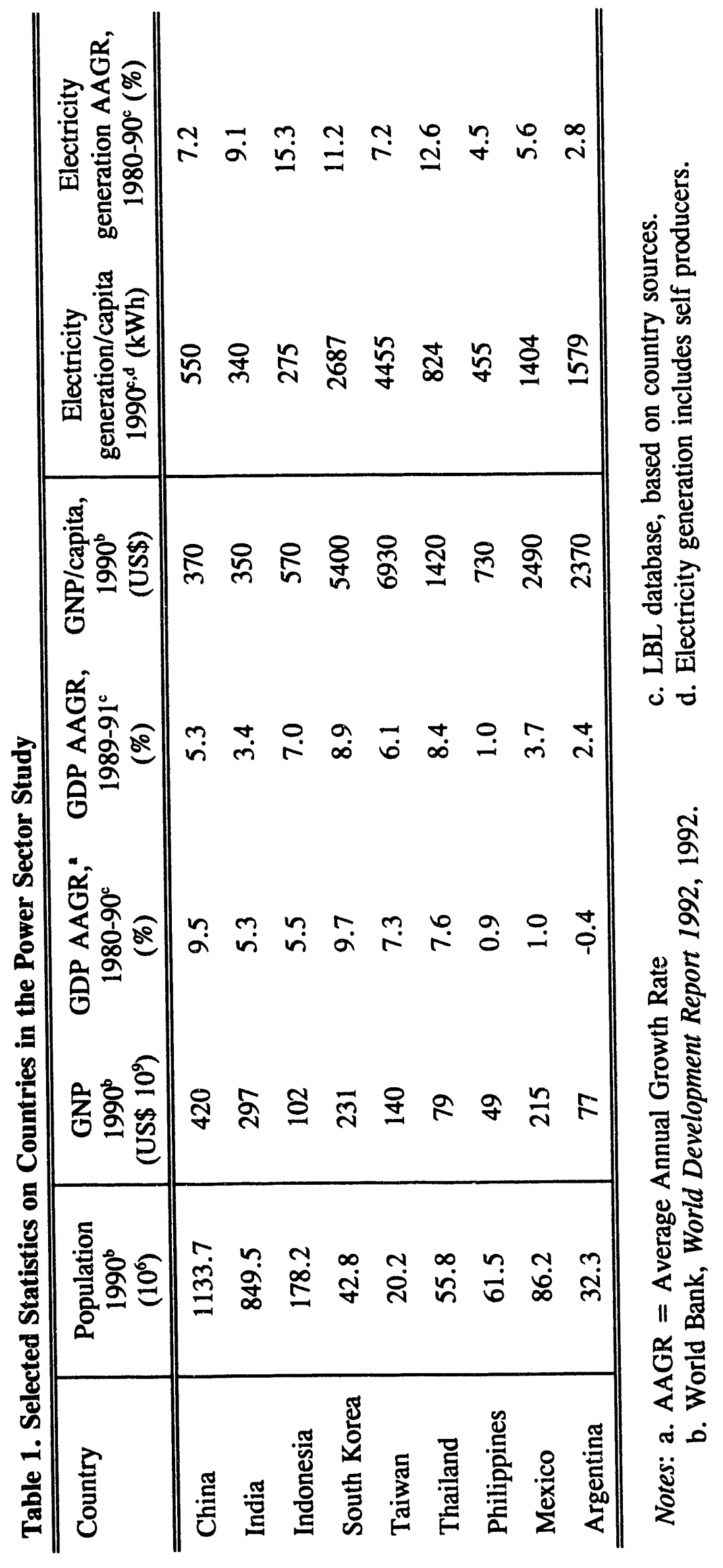




\section{CHINA}

\subsection{Introduction}

With over a fifth of the world's population (1.13 billion), China is currently the fourth largest producer of electricity. China has been one of the world's fastest growing economies over the past decade but electricity shortages have impeded economic growth. One study noted that $80 \%$ of the generating units cannot have planned outages for proper maintenance because of the shortages, thereby raising the risk of breakdowns. ${ }^{1}$ Even though the country exceeded expectations for capacity installation in its last five-year plan (1986-90), shortages of 20-30\% of peak demand are still common, especially in the rapidly growing southern provinces. ${ }^{2}$

Prior to the re-organization in March 1993, the Ministry of Energy (MOE) was the principle organization responsible for electricity supply. The MOE oversaw the National Corporation for Power Generation (NCPG), which is responsible for the development of new plants. The NCPG coordinates its activities and investment with local governments, the Huaneng group, and private domestic and foreign investors. ${ }^{3}$ The Department of Energy in the State Pianning Commission (SPC) coordinates electricity planning and investment in China's overall five-year plans. The power system includes five regional power companies, 10 provincial power companies, the Huaneng group, and several small power companies. Increasingly, the SPC's role in planning is becoming more indicative and less prescriptive as the country moves toward a mixed-socialist economy. The MOE focuses on improving the efficiency of power generation, while end-use efficiency planning and programs are dispersed in a variety of ministries as well as with local governments.

Between 1980 and 1990, China's total installed capacity expanded at an average annual rate of 7.7\% (Table 2-1). The total capacity at the end of 1991 was around $150 \mathrm{GW}$. Coal continues to be the primary fuel for electricity generation, accounting for about $70 \%$ of the total. Hydroelectric generation rose at an average rate of $8.1 \%$ in 1980-90, with installed capacity amounting to $38 \mathrm{GW}$ at the end of 1991 . Oil-fired plants, which accounted for around $25 \%$ of power sector fossil fuel use in 1980, declined in the past decade as the government sought to reduce oil consumption. However, recently, parts of southern and eastern China have begun to import oil to feed small power plants that were recently constructed to help meet surging electricity demand.

By 1989 rural electricity generation accounted for about one-third of total public generation and reached nearly $88 \%$ of Chinese villages. The share of rural electricity from local,

\footnotetext{
'Institute of Nuclear Energy Technology, "Electricity System Performance in China," Tsinghua University, Beijing, China, March 1991.

2 "China's generation gap: Massive power program fails to match soaring demand," Far Eastern Economic Review, June $11,1992$.

${ }^{3}$ The Huaneng group, established in 1985, is the largest semi-public power company in China and generates about one-fourth of China's electricity.
} 
non-grid sources grew from $20 \%$ in 1985 to $30 \%$ in 1989 as local governments expanded investment in mini-hydro and mini-thermal plants. ${ }^{4}$

Industry accounts for a higher share of electricity consumption (73\%) than in other developing countries, but rapid growth in consumption is occurring in the commercial and especially the residential sectors. Residential electricity demand has been exploding mainly because of domestic appliance penetration, which for refrigerators and televisions jumped from virtually nothing in 1982 to over $80 \%$ of homes by 1990 in the larger cities.

Table 2-1. China Power Sector Statistics

\begin{tabular}{|c|c|c|}
\hline & 1990 & AAGR \\
\hline Installed Capacity $(\mathrm{GW})^{\mathrm{b}}$ & $137.8(100 \%)$ & 7.7 \\
\hline Hydro & $36.0(27.3 \%)$ & 5.9 \\
\hline Thermal & $101.8(72.7 \%)$ & 8.4 \\
\hline Generation $(T W h)^{c}$ & $572.5(100 \%)$ & 7.2 \\
\hline Hydro & $126.7(22.1 \%)$ & 8.1 \\
\hline Thermal $^{d}$ & $445.8(77.9 \%)$ & 7.0 \\
\hline Consumption $(\mathrm{TWh})^{\mathrm{c}}$ & $442.6(100 \%)$ & 7.4 \\
\hline Industry & $323.9(73.2 \%)$ & 6.5 \\
\hline Residential & $44.1(10.0 \%)$ & 16.5 \\
\hline Commercial & $25.6(5.8 \%)$ & 12.7 \\
\hline Agriculture & $39.2(8.6 \%)$ & 5.1 \\
\hline Transportation & $9.7(2.1 \%)$ & 15.0 \\
\hline
\end{tabular}

Notes: a. Installed capacity by the end of 1991 reached $151.5 \mathrm{GW}$ (38 GW hydropower and $113 \mathrm{GW}$ thermal power). The Qinshan nuclear plant (300 MW) began operation in December, 1991. Public generation that year reached $624 \mathrm{TWh}$, of which $125 \mathrm{TWh}$ was hydro and the rest thermal. (Self-producers generated 53.6 TWh that same year.) Ruoyu Zhai, "Electric Power Industry and Environnıntal Protection in China," Department of Safety and Environmental Protection, Ministry of Energy, October, 1992.

b. Self-producers $(11 \mathrm{GW})$ may be included.

c. Not including self producers.

d. Fuel use in thermal power plants was $91 \%$ coal, $8 \%$ oil, and $1 \%$ gas.

\subsection{Resources for Electricity Generation ${ }^{5}$}

\footnotetext{
${ }^{4}$ Institute of Nuclear Energy Technology, op cit., Ref. 1.

S Statistics are taken from Sinton, J.E. (ed), China Energy Databook, 1992 Edition, LBL-32822, Lawrence Berkeley Laboratory, Berkeley, CA, November 1992, unless otherwise indicated. The compilation draws on data from China's State Planning Commission, the Chinese State Statistical Bureau, the Chinese Ministry of Energy, the China National Energy Investment Corporation, and the China National Coal Corporation.
} 
Coal resources in China are estimated at 4,000 billion tons (anthracite and bituminous). In 1990, 1.1 billion tons of coal were produced; about $25 \%$ was used for power generation. The high ash content of Chinese coal $(27 \%)$ produces lower heat values than desired.

The geography of coal distribution has strained the country's transportation system creating bottlenecks in coal supply. Resources are located mainly in the northern provinces (Xinjiang, Shanxi, Shaanxi, Inner Mongolia), and are distant from the high-demand industrialized areas on China's northeast and southeast coastline. It is estimated that nearly 200 million tons were stored naticil-wide awaiting transport in $1992 .^{6}$ In 1992 , the Chinese government approved the construction of a second railway $(820 \mathrm{~km})$ from West China to the coastal areas to alleviate the coal transport problem. The project will require an investment of 10.7 billion Yuan ( $\$ 2$ billion) and will take six to seven years to complete. ${ }^{7}$

China's other great resource is hydropower, which has an estimated potential of $379 \mathrm{GW}$. (Installed hydropower capacity in 1991 was $38 \mathrm{GW}$.) Most of the country's resources are located in the south and southwest, however, 2,000 to $3,000 \mathrm{~km}$ away from main demand centers. The construction of appropriate transmission networks complicates the development of hydro resources. About one-fifth of the exploitable capacity is suitable for small-scale projects (less than $6 \mathrm{MW}$ ), and holds the potential for extending electricity to remote areas without having to extend the transmission grid.

Relative to its abundant coal resources, China is poorly endowed with oil and natural gas, especially on a per-capita basis. As of 1990, proved oil reserves were given as 3,264 million tons $(\mathrm{Mt})$, with an estimated additional recoverable amount of $15,000 \mathrm{Mt}^{8}$ World Energy Council reserve estimates for natural gas are 1.2 billion cubic meters, although much of this low figure is due to the lack of exploration. Even if more exploration turns up new oil and gas resources, other sectors have higher priority for using these fuels than the power sector (for example, replacing coal-based heating in cities with natural gas).

Uranium reserves are estimated at 1-2 million tons, adequate for China's near-term needs for its nuclear power generation over the next decade.

\subsection{Forecast of Electricity Demand}

Given the potential for sustained high levels of economic growth in the Chinese economy, and the relatively under-electrified state of the residential and commercial sectors, it is likely that electricity demand will be constrained by supply over the 1990s. National planners had estimated the GNP growth rate at $6 \%$ per year through the year 2000 , but recent experience

\footnotetext{
6 "China's generation gap," op cit., Ref. 2.

7 "New railway will reduce coal transport problem," Asian Energy News, October 1992.

${ }^{8}$ World Energy Council, 1992 Survey of Energy Resources, 1992.
} 
indicates that growth may be considerably higher than that. GNP growth for 1992 was an astounding $12 \%$. New estimates for the rest of the 1990 s lie in the $8-9 \%$ range.

Government documents typically speak in terms of the electricity production needed without explicitly referring to the dynamics of the underlying demand. The value of $1,200 \mathrm{TWh}$ of total production in the year 2000 had been the goal. This would imply a growth in production averaging $6.8 \%$ per year between 1990 and 2000, somewhat above the assumed GNP growth rate. Assuming that the percentage of losses in electricity supply diminishes over time, as the government intends, electricity demand could grow slightly higher than production. The resulting ratio of electricity demand to GNP of just over 1 would roughly correspond to the experience in the 1985-90 period (which was quite different from the 1980-85 period in which the ratio declined).

Researchers at Tsinghua University, a leading center for energy demand studies, performed a sectoral projection of future electricity use in which total consumption grows at an average annual rate of $6.6 \%$ from 1990 to 2000 (Table 2-2).

Table 2-2. China Electricity Consumption Projection

\begin{tabular}{cccccc}
\hline \multirow{2}{*}{ Year } & \multicolumn{3}{c}{ Electricity Consumption (TWh) } & \multirow{2}{*}{ Total per Capita $(\mathrm{kWh})$} \\
\cline { 2 - 4 } & Industry & Household & Others & Total & \\
\hline 1990 & 452.2 & 43.9 & 89.6 & 585.6 & 520.2 \\
1995 & 599.1 & 66.3 & 123.9 & 789.3 & 653.4 \\
2000 & 816.5 & 104.0 & 185.9 & $1,106.4$ & 865.7 \\
2005 & 1021.1 & 146.0 & 244.3 & $1,411.4$ & 1067.6 \\
\hline \hline
\end{tabular}

Source: Qiu Daxiong, Institute for Techno-economics and Energy Systems Analysis, Tsinghua University, Beijing, in Asian Development Bank, Environmental Considerations in Energy Development, 1991.

Household consumption is projected to grow at $8 \%$, but this seems conservative. Along with further increase in appliance saturation, several new factors will bring continued growth in residential demand. Many urban households are buying electric heaters. New building codes that allow housing to be constructed with $10 \mathrm{Amp}$ circuitry instead of the $5 \mathrm{Amp}$ wiring that has been standard will permit greater use of high-wattage appliances. Lastly, the use of window airconditioners is rising. Rising residential demand and use of appliances worsens the peak to base demand ratio by increasing the evening peak. The historic resistance to using oil for elestricity generation means that coal-fired plants are run in a cycling mode to meet peak demand in regions without hydropower, leading to the inefficient utilization of coal plants.

\subsection{Plans for Power Sector Development}

As of end-1992, the most recent official plans for power sector expansion were those from late 1988 . These called for increasing installed capacity to $240 \mathrm{GW}$ by the year 2000 , an 
average of roughly $10 \mathrm{GW}$ per year (Table 2-3). The share of hydropower in the generation mix remains at around $20 \%$, while the thermal share declines slightly as nuclear power comes to play a larger role. Coal-based plants are expected to account for the bulk of future capacity and generation.

Table 2-3. China Power Sector Plans as of late-1988

\begin{tabular}{|c|c|c|c|c|}
\hline Year & Hydro & Thermal & Nuclear & Total \\
\hline \multicolumn{5}{|c|}{ Installed Capacity (GW) } \\
\hline 1990 & $39.0(29.6 \%)$ & $92.3(70.1 \%)$ & $0.3(.2 \%)$ & $131.7(100 \%)$ \\
\hline 1995 & $54.4(30.6 \%)$ & $121.3(68.2 \%)$ & $2.1(1.2 \%)$ & $177.8(100 \%)$ \\
\hline 2000 & $74.7(31.1 \%)$ & $159.3(66.4 \%)$ & $6.0(2.5 \%)$ & $240.0(100 \%)$ \\
\hline 2010 & $113.5(29.1 \%)$ & $258.6(66.3 \%)$ & $18.0(4.6 \%)$ & $390.0(100 \%)$ \\
\hline \multicolumn{5}{|c|}{ Generation (TWh) } \\
\hline 1990 & $128.8(20.2 \%)$ & $507.9(79.8 \%)$ & $0.0(0 \%)$ & $636.7(100 \%)$ \\
\hline 1995 & $179.5(20.9 \%)$ & $667.0(77.8 \%)$ & $10.5(1.2 \%)$ & $857.0(100 \%)$ \\
\hline 2000 & $240.0(20.0 \%)$ & $930.0(77.5 \%)$ & $30.0(2.5 \%)$ & $1200.0(100 \%)$ \\
\hline 2010 & $394.0(20.2 \%)$ & $1457.0(74.7 \%)$ & $99.0(5.1 \%)$ & $1950.0(100 \%)$ \\
\hline
\end{tabular}

Note: a. Generation includes self-producers. Installed capacity may include self-producers as well.

Source: Chinese Ministry of Energy projections in Commission of the EC, Power Sector Study of China, March 1990.

Given that China's economic growth is likely to be much higher than was expected in 1988 , these plans no doubt understate the capacity growth that Chinese planners would currently like to see occur. A recent presentation suggested a capacity increase to $280-300 \mathrm{GW}$ by the year 2000 , considerably higher than the $240 \mathrm{GW}$ figure given earlier. ${ }^{9}$ Generation for 2000 is projected to reach $1350 \mathrm{TWh}$. The implied average growth rate of 7.5\%/year in 1991-2000 from the new projections, is almost exactly what was achieved in the 1980-1990 period. Actual capacity installation appears to be proceeding at this higher rate. In 1992, 30 projects (mainly medium and large sized thermal plants) were initiated with a total capacity of $17.5 \mathrm{GW}$; plans for 1993 call for initiating projects with a total of $20.7 \mathrm{GW} .{ }^{10}$ The capacity mix is likely to change over the decade as well. In 1990 most of the thermal capacity was coal-fired. In 2000 the total will likely include more gas and/or oil-fired capacity. Table 2-4 and Figure 2-1 show our estimate of installed capacity by type in the year 2000 .

The government is planning to increase the numbers of larger, more efficient units in the 300-600 MW range built near the mine mouth. This will increase generation efficiency, reduce coal transport needs, and limit added pollution in urban areas. However, due to the distance of

\footnotetext{
${ }^{9}$ Wang Zhongan, State Planning Commission, "State of Electric Power Sector in China," talk delivered at the U.S.-China conference on Energy, Environment and Market Mechanisms, Lawrence Berkeley Laboratory, October 24 - November 6, 1992.

${ }^{10}$ China Daily, January 8, 1993.
} 


\section{China Power Development Plans Installed Capacity}

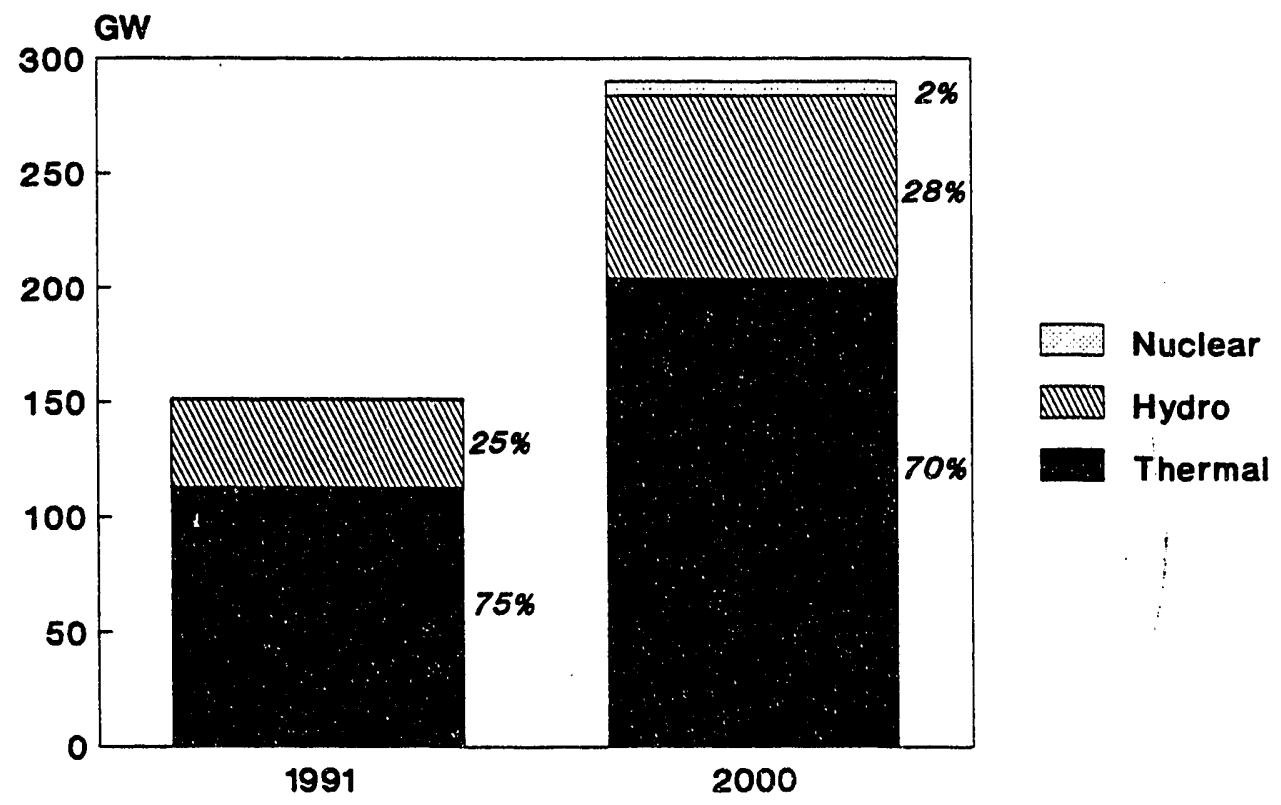

Figure 2-1 
the mine-mouth plants to major population centers, the government has had difficulty recruiting qualified technical labor and is facing labor shortages for the plants' construction and operation. The increased mine-mouth generation will also require construction of new transmission lines.

Table 2-4. China Projected Installed Capacity (GW)

\begin{tabular}{lcc}
\hline \hline & 1991 & $2000^{\circ}$ \\
\hline \hline Hydro & 38.0 & 80 \\
Thermal" & 113 & $194-214$ \\
Nuc,ar & 0.3 & 6 \\
Total & 151.3 & $280-300$ \\
\hline \hline
\end{tabular}

Note: a. Of the $40-60 \mathrm{GW}$ incremental increase relative to the earlier plan, we assume that $5 \mathrm{GW}$ is hydro ard the remainder thermal.

Currently, the majority of the country's thermal capacity ( $70 \%$ of the total) is medium sized (100-300 MW) plants. In the past decade, large numbers of small thermal power plants were commissioned as local governments with limited financial resources sought short-term solutions to power shortages. Cogeneration also is receiving heavy emphasis for future development. If $10-15 \%$ of Chinese small-sized boilers were retrofitted for cogeneration, some $10 \mathrm{GW}$ of new capacity would be made available. ${ }^{11}$

The plans call for fuller exploitation of the relatively modest hydro resources in the coastal provinces and development of numerous projects greater than $50 \mathrm{MW}$ in the South and Southwest, including the development of the large hydro projects on the Yangtze and Yellow rivers. ${ }^{12}$ The increase in hydro capacity may be hampered by the high costs of developing transmission networks from the southwest to the southeast and northeast regions. The most ambitious hydropower project is the Three Gorges project with a total estimated capacity of 17 GW. The project's relative proximity to load centers makes it a prized development for the government. Although it faced numerous delays due to opposition from local villages and environmental groups, the go ahead for project initiation has been given and clearing operations have begun at the base of the first dam. The People's Construction Bank of China has already established a Three Gorges branch to seek funds for the 10 billion yuan project, of which 6 billion yuan may be borrowed from abroad. So far, the government has allocated 50 million yuan for relocation costs. ${ }^{13}$

Nuclear power, while still in the early stages of development, is viewed as playing an increasingly important role in the provinces that lack indigenous coal or hydro resources

\footnotetext{
"Institute of Nuclear Energy Technology, op cit., Ref. 1.

12 Wang Zhongan, "Actual State of China's Energy Industry and Expected Development Policy," talk delivered at U.S.-China Conference on Energy, Environment and Market Mechanisms, Lawrence Berkeley Laboratory, Berkeley, CA, October 1992.

13 "China seeking foreign funds for world's largest dam," Asian Energy News, November 1992.
} 
(Guangdong, Northeast China, Zhejiang, Southern Jiangsu). Currently China's Qinshan reactor $(300 \mathrm{MW})$ is operational and was developed using domestic designs. At least one and possibly two more $600 \mathrm{MW}$ additions are planned for this complex. The Daya Bay plant in Guandong province $(2 \mathrm{GW})$, a foreign investment enterprise, will probably not come on-line until 1996, although additions are planned for this complex as well. Overall, $6 \mathrm{GW}$ of nuclear generation capacity are planned by the year 2000 . A recent Chinese report discusses making the eastern coastal areas a base for nuclear power generation using a modular approach to plant sitings for its pressurized water reactors (PWR) ${ }^{14}$ In the more distant future (2020), the Chinese hope to develop a breeder reactor.

Given the expected supply shortages, the government is looking to innovative solutions for China's electricity needs. The change in strategy closely parallels Deng Xiaoping's push to encourage a "socialist market economy" in which the central sector's role in electricity planning and investment is becoming less important. Increasingly, the central government is relying on provincial investment and private foreign investment to keep pace with electricity demand. The government is encouraging Build-Operate-Transfer (BOT) projects and more private participation in the utility sector. Hopewell, an international power development firm, recently completed a large $700 \mathrm{MW}$ BOT plant in Guangdong. ${ }^{15}$ In rural areas, local governments have been expanding the non-grid power supply.

\subsection{Financial Issues}

Electricity-related investment accounts for almost half of China's total energy industry investment. In 1990, 36.7 billion yuan ( $\$ 7.7$ billion) out of a total 83.7 billion ( $\$ 17.4$ billion) was planned for electric power investment. ${ }^{16}$ More than half of the investment for power development comes from local and provincial governments, power users, and other investors. ${ }^{17}$

The estimated investment required for capacity expansion only in 1991-2000 is at least 350 billion yuan. (This assumes an average cost of 2500 yuan $/ \mathrm{kw}$ ). For 1993, direct government investment in the power sector may only run about 15.7 billion yuan out of a total planned 52.2 billion yuan. ${ }^{18}$ Local government, the Huanneng group, and foreign private investment are slated to make up $40 \%, 15 \%$, and $10 \%$ of the total investment respectively. If the 52.2 billion yuan goal is reached, it would be a 50\% increase from 1992 investment. With GNP growth rates on the order of $8-9 \%$ or more predicted for the next decade, the central government will need

\footnotetext{
${ }^{14}$ Bao Yunqiao, "The Status and the Development of Strategic Research of China's Nuclear Power," World Energy Council, 15th Congress Proceedings, 1992.

is "China's generation gap," op cit., Ref. 2.

${ }^{16}$ Sinton, J.E., op cit., Ref. 5.

${ }^{17}$ The drawing of investment from major power users is a new policy for local government as it attempts to harness the necessary resources to meet electricity demand. The governments are calling upon the large industrial and comrnercial electricity consumers to "contribute" to the construction of new plants in exchange for long-term price contracts on electricity.

${ }^{18}$ China Daily, op cit., Ref. 10.
} 
to continue to devote a considerable percentage of its energy budget into power sector expansion, as well as allow local governments more flexibility in their financing, including foreign investment.

The resolution of pricing issues affects future investment. A portion of the electricity sold to state enterprises is currently subsidized; some enterprises receive electricity at half the average marginal cost of generation, which is around $25 \mathrm{fen} / \mathrm{kWh}(4.3 \mathrm{USc} / \mathrm{kWh})$. Policy is changing in this area, however. In January 1993, the central government announced that it will free up coal prices for power generation by the end of the year. ${ }^{19}$ To ease the burden on power companies, the government also plans to gradually remove subsidized quotas for factories in the state sector. This oolicy should not only increase power company revenues, but also encourage a. inore rational consumption of electricity by the state enterprises over the long term.

\subsection{Environmental Considerations}

The projected growth in coal-fired generation will exacerbate already serious environmental problems in China. Existing coal-fired power plants have no emissions controls, and only the larger plants under construction will have control particulate controls.

Since the high rates of air pollution in urban areas (and coal transport problems) limit the development of coal-fired generation near major cities, planners are targeting the expansion of mine-mouth power in coal-rich regions. Such plants have been limited by the lack of water for cooling. In Shanxi, China's main coal-producing province, the plans call for construction of a diversion canal from the Yellow River to serve as a cooling source for mine-mouth plants. By 2000 the province plans to utilize $8 \mathrm{GW}$ of its $21 \mathrm{GW}$ capacity for electricity exports to other provinces. ${ }^{20}$ The province recently signed an agreement with an investor from Hong Kong to construct about $2000 \mathrm{MW}$ of mine-mouth power. ${ }^{21}$ Not all provinces have the resources to finance such large-scale water projects, and the negative local environmental effects may hamper mine-mouth power expansion.

Although greater reliance on mine-mouth plants will limit growth in urban air pollution, it will not solve other problems. The coal extraction process increases surface erosion, and can pollute water resources by such effects as acid mine water and sludge drainage. The increasing production from rural mines with more primitive mining processes is likely to worsen local pollution from coal extraction.

In the south, the use of coal has contributed to high levels of acid precipitation. According to the head of China's Environmental Protection Bureau, total $\mathrm{SO}_{2}$ emissions between

\footnotetext{
${ }^{19}$ China Daily, January 10, 1993.

${ }^{20}$ China Daily, January 1993.

21 "Shanxi to export electricity," Asian Energy News, November 1992.
} 
1987 and 1992 increased 5.4\%/year. ${ }^{22}$ Power plants accounted for nearly one-third of total $\mathrm{SO}_{2}$ emissions in 1989 (Table 2-5). The Bureau director also noted that China is hoping to limit total $\mathrm{SO}_{2}$ emissions to $20 \mathrm{Mt}$ by the year 2000 , or only a $23 \%$ increase from 1991 levels.

Table 2-5. Estimates of Air and Particulate Emissions from China's Electricity Sector, 1989 (million tons)

\begin{tabular}{llll}
\hline & Coal consumed & Particulates & Sulfur Dioxide \\
\hline \hline Electricity production & 220 & 5.1 & 4.5 \\
Total Economy & 1000 & 13.6 & 14.8 \\
\hline \hline
\end{tabular}

Source: Comprehensive Planning Department, Energy and the Environment (Chinese), MOE \& Chinese Energy Society, February 1992.

Due to the high capital cost of flue gas desulfurization, most of China's efforts have focused on controlling emissions of particulates. Recent plants have included technology to reduce particulate emissions, including the use of electrostatic precipitators. The government hopes to expand coal washing plants to remove excess particulate matter and reduce sulfur content, and to improve the transportation/distribution system to promote better access to higher quality coal.

China's intensive use of coal for power generation as well as in industry and buildings makes the country the third largest source of anthropogenic carbon dioxide emissions in the world. Carbon production from fossil fuel combustion, cement production and gas flaring in 1989 was estimated at $652 \mathrm{Mt}$, or $11 \%$ of the world total. ${ }^{23}$

Large-scale hydropower is also fraught with environmental and social problems, such as serious population dislocation. This was a major objection to the development of the Three Gorges project, a massive $17 \mathrm{GW}$ hydropower project in the Yangtze river. Another drawback in populous China is the loss of farmland.

\subsection{Electricity Supply Efficiency}

The gross generating efficiency of China's coal-burning plants improved slightly from $26 \%$ to $27 \%$ between 1980 and $1989 .{ }^{24}$ Efficiency remained low despite the addition of many new, large ( $>200 \mathrm{MW}$ ) and more efficient plants. Both the poor quality of the coal and the proliferation of small, inefficient coal-burning plants built by local authorities have restrained efficiency improvement. The average fuel consumption of all Chinese coal-burning power plants

\footnotetext{
22 China Daily, January 24, 1993.

${ }^{23}$ Sinton, J.E., op cit., Ref. 5.

24 Ibid.
} 
is estimated at $11,600 \mathrm{~kJ} / \mathrm{kWh}(31 \%)$, while the smaller plants have heat rates of $23,000 \mathrm{~kJ} / \mathrm{kWh}$ $(16 \%) .^{25}$

Even if they used better quality coal, the larger Chinese generator sets would have efficiencies around $10 \%$ lower than comparable equipment made in industrialized countries. By the year 2000, the Chinese hope to improve the average coal-burning plant efficiency to above $33 \%$. They aim to build new capacity with heat rates of at least $9700 \mathrm{~kJ} / \mathrm{kWh}(37 \%)$, substituting low-performance small plants with higher-performance large plants, and lowering the heat rates of existing $125 \mathrm{MW}, 200 \mathrm{MW}$ and $300 \mathrm{MW}$ generating sets through design modifications. ${ }^{26}$ However, the capital limitations for cash-strapped local govemments may lead to continuing expansion of less efficient, smaller plants, especially since the necessary capital infrastructure to support large-scale lending in China is still developing. Since the mid-1980s regional and provincial power bureaus have operated as profit-making companies, but the current tariff structure produces disincentives to operate the newest, more efficient plants for base load. ${ }^{27}$

Official Chinese statistics have traditionally reported very low losses (8\%) from the transmission and distribution (T\&D) of electricity, but actual T\&D losses are much higher. A recent study of the T\&D losses in five municipalities estimated total losses at $16 \% .^{28}$ It is likely that nationwide losses are even higher, as almost a third of electricity is transported through rural networks where losses may be as high as $30 \%$.

Reducing these losses will require increased investment to reconfigure the grid, improve power factors, reduce transformer losses and increase conductor cross-section and voltages. Higher-efficiency transformers are made in China and are cost-effective for new installations as well as for the replacement of existing equipment. From the national perspective the cost of conserved electricity (CCE) for installation of such a transformer is estimated to be $40-60 \%$ of the national average marginal cost of electricity $(25 \mathrm{fen} / \mathrm{kWh}$ or $4.3 \mathrm{USc} / \mathrm{kWh})$, but the higher initial cost is a powerful disincentive in capital-scarce China. ${ }^{29}$ Investments in power factor correction such as the installation of capacitor banks on distribution lines have the best savings

\footnotetext{
${ }^{25}$ Sathaye, J., Economics of Improving Efficiency of China's Electricity Supply and Use: Are Efficiency Investments CostEffective?, Draft, Lawrence Berkeley Laboratory, Berkeley, CA, May 1992.

${ }^{26}$ Ruoyu Zhai, Electric Power Industry and Environment Protection in China, Department of Safety and Environmental Protection, Chinese Ministry of Energy, October 1992.

${ }^{27}$ Under China's "two-tiered" tariff structure power producers are paid different prices for electricity. This pushes the power grid to use the least cost source for generation; since the newest plants built are also the most costly to the grid (due to capital costs) the less efficient plants are used to draw power are operated first. For more information see Todd M. Johnson, "China's Power Industry, 1980-1990: Price Reform and its Effect on Energy Efficiency," Energy, November, 1992. 1991.

${ }^{29}$ Sathaye, J., op cit., Ref. 25.
} 
potential for T\&D loss reduction: the CCE is estimated to be only $2-6 \mathrm{fen} / \mathrm{kWh}(0.3-1.0$ $\mathrm{USc} / \mathrm{kWh})$.

Government plans call for the seven major power networks (Northeast, North China, East China, Central China, Northwest, Southwest, and South China) to become increasingly integrated over the next 20 years. Plans also include the construction of high-voltage $(500 \mathrm{kV})$ transmission lines to allow for more efficient transmission from high-resource areas to highdemand areas.

\subsection{Electricity End-Use Efficiency}

Industry. An estimated half of the total electricity generation in China is used to drive various motors. ${ }^{30}$ Over the past decade, motor system efficiency in industry has been upgraded by the installation of more efficient models, by making modifications at the time of rewinding, by improving power factor characteristics of systems, and by installing variable-speed drives, which are made in China. Chinese manufacturers produce "high-efficiency" motors, but in fact these motors only achieve the efficiencies of standard U.S. motors. ${ }^{31}$ The Chinese highefficiency motors are quite cost-effective relative to standard models. The estimated CCE of high-efficiency motor installations is 8-12 fen/kWh (1.4-2.1 USc/kWh). Unfortunately, one motor manufacturer recently terminated his line of efficient products because of a drop in demand for these more expensive models. China also produces relatively efficient blowers, pumps, and other electricity end-use equipment for industry. Much of this equipment is produced by joint ventures between Chinese and foreign companies established to produce for domestic and export markets.

There remains a significant potential for savings from the improvement of end-use equipment, as well as from the optimization of production processes and modernization of plants. Over the past decade, the Chinese government has made various efforts to encourage production of more energy-efficient end-use equipment. It supports development of new designs at R\&D institutes. The Ministry of Machinery and Electronics regularly publishes lists of efficient and inefficient equipment. The latter are supposed to be eliminated. In some cases, inefficient models have in fact been removed from production; but in others, manufacturers have continued to produce the older equipment trusted by users. To encourage manufacturers to produce the new, more-efficient designs, the State offers low-interest loans and preferential treatment in terms of taxes.

The planned phase-out of subsidized electricity prices will improve the attractiveness of investments in more efficient equipment. On the other hand, as quotas and targets play a reduced role in determining economic activity, the central government will lose its power to force

\footnotetext{
30 This includes free-standing motors coupled to other machinery, as well as motors integrated into pumps, fans and other machines used in various economic sectors.

${ }^{31}$ Sathaye, J., op cit., Ref. 25. This comparison is based on the reported efficiency of three different sizes of identical motors of U.S. and Chinese manufacture. The Chinese model was the Y-Series high efficiency three-phase induction motor made by China's best motor manufacturer. The U.S. figures are averages over seven different motor manufacturers.
} 
factories to make investments in energy conservation. Furthermore, because of capital scarcity and a lack of adequate information, factories may continue to prefer the cheaper more inefficient products. Because inefficient equipment is often priced very low, users are discouraged from purchasing more efficient products.

Residential. Residential electricity use in China is probably more efficient than in most developing countries. Since much of the growth in ownership of televisions and refrigerators took place in the past decade, the stock of these appliances is relatively modern and efficient. Because the supply of electricity in most apartments is constrained by a 3-ampere fuse and 5ampere wiring, total power use cannot exceed 1000 watts.

Color TV sets have a rating of about 40-50 watts, while the commonly used 165-liter refrigerator draws about 70-80 watts. While accurate comparison of the efficiency of refrigerators produced in China will require further study (test procedures vary in different countries), there are some indications of room for improvement in Chinese models. For example, the current 170-liter model produced by Snowflake Corporation in Beijing consumes about $32 \mathrm{kWh} /$ month, whereas the Shanghai Aerospace Refrigerator factory is producing a new model which reportedly consumes $24 \mathrm{kWh} /$ month. The newer model still consumes more electricity than models in other developing countries. For example, the average monthly consumption in Korea was $20 \mathrm{kWh} /$ month in 1987, and has improved slightly since then. ${ }^{32}$

Lighting is one area where dramatic electricity demand reductions could be achieved by use of comp' $t$ fluorescent lamps (CFLs). CFLs are being produced in China for domestic and export markets. There are currently $10 \mathrm{CFL}$ factories operating, but the lamps are of inconsistent quality. Unclean production processes and poor quality of raw materials cause low quality finished products, and lamp lifetime is further shortened by the voltage fluctuations which are common on the Chinese grid. Despite these problems, the Chinese CFLs have good conservation economics, with a CCE of $13 \mathrm{fen} / \mathrm{kWh}(2.2 \mathrm{USc} / \mathrm{kWh})$ which compares favorably with the residential tariff of around $20 \mathrm{fen} / \mathrm{kWh}(3.4 \mathrm{USc} / \mathrm{kWh}){ }^{33}$ If the CFLs were to last the 8000 hours typical of bulbs in industrialized countries, then a CCE of $3 \mathrm{fen} / \mathrm{kWh}(0.5 \mathrm{USc} / \mathrm{kWh})$ could be achieved. Producing high quality CFLs would require improvement in production lines.

In the city of Shenzhen, local utility planners are considering the use of demand-side management as a tool to restrain electricity growth. The program is currently in the early stages of data collection and assessment. If such a program is successful, it could be replicated in other high demand areas in the southern and eastern provinces.

\subsection{Conclusion}

\footnotetext{
${ }^{32}$ Meyers, S., S. Tyler, H. Geller, J. Sathaye and L. Schipper, Energy Efficiency and Household Electric Appliances in Developing and Newly Industrialized Countries, LBL-29678, Lawrence Berkeley Laboratory, Berkeley, CA, December 1990.

${ }^{33}$ Sathaye, J., op cit., Ref. 25.
} 
The combination of already serious electricity shortages in much of China with the potential for rapid economic growth is leading planners to boost their targets for capacity expansion from previous levels. Current projections call for the addition of some 80-100 GW of thermal power plants and around $40 \mathrm{GW}$ of hydropower between 1991 and 2000. Improvements in coal transport and the construction of new high-voltage transmission lines will allow greater utilization of the country's ample coal and hydropower resources. However, problems with coal transport are leading to greater emphasis on construction of mine-mouth power plants. Some $6 \mathrm{GW}$ of nuclear power is also targeted to come on line by 2000 , with eventual plans for considerably more.

Relative to the past, a smaller share of the new capacity will be financed by the central government. The systemic restructuring taking place is giving provincial and local governments a greater role in providing for new capacity, and efforts are being made to attract private investment (domestic and foreign). This trend is likely to bring an increase in oil- and perhaps gas-fired capacity, since such projects have low capital cost, short lead time, and do not depend on delivery of coal supplies.

Although the expansion of energy supply is still given top priority, environmental issues are becoming increasingly important in densely-populated China. Local air pollution and acid precipitation constrain expansion of coal-fired power, and lack of water for cooling may limit mine-mouth power plants. The shear magnitude of the planned expansion in coal use may lead to increasing international assistance for various $\mathrm{CO}_{2}$ abatement strategies. For hydropower, population dislocation and loss of farmland are problems in many cases.

In order to meet the rising electricity demand and lessen adverse environmental impacts of expanding generation, the government is recognizing the need to place more emphasis on improving the efficiency of electricity supply and use. Various efforts underway will contribute to increased generating efficiency and reduction in T\&D losses. Pricing reform will create greater interest on the part of users, but the higher cost of more efficient equipment is a constraint. Reaping the sizable efficiency potential will require stronger standards and other programs. 


\section{INDIA}

\subsection{Introduction}

Although installed generating capacity has expanded dramatically in India over the last decade, reaching nearly $70 \mathrm{GW}$ in 1992 , electricity continues to be in short supply. This is especially the case in the country's northern and southern regions, where the demands from industrial expansion and rural electrification outpace new supply. The power sector is plagued by high transmission and distribution losses (including high rates of power theft), limited national grid integration, delays in new construction and coal transport problems. Most end-use equipment is relatively inefficient, and serious efforts to promote electricity end-use efficiency are just beginning.

Thermal power and hydropower are the basis of India's electricity generation, accounting for $72 \%$ and $25 \%$ of the total in FY 1991, respectively (Table 3-1)'. Over the past decade, thermal generation has grown more rapidly $(11.7 \% /$ year $)$ than hydro generation $(4.4 \% /$ year $)$. Most of the thermal capacity uses domestic coal; although, gas-fired plants have witnessed considerable growth over the past few years. Fuel oil is only used as a start-up fuel in coal-fired plants and to permit their operation as load-followers. The decreasing proportion of hydropower in the overall power generating mix has been a concern for energy planners. By the end of FY 1991 , hydropower's share, which once stood at $40 \%$ of total capacity was only $28 \%$. This decline has strained the power system by forcing thermal stations to "back down" their generation during off-peak hours. The lack of oil and natural gas for the power sector further complicates the problem of meeting peak demand.

The industrial sector accounts for $44 \%$ of total electricity consumption, while agriculture (mainly pumpsets) accounts for another $27 \%$. Consumption of electricity in the residential sector is growing fastest, however, at $16 \%$ annually. In rural areas, rapid electrification is still ongoing. An estimated $83 \%$ of Indian villages were hooked up to electricity in 1991, up from about $64 \%$ in 1985 . Around $88 \%$ of the total population (urban and rural) currently has access to electricity. ${ }^{2}$

Industrial self-production has increasingly been used to meet the demand for electricity not served by utilities. Much of this takes place through reliance on stand-by private generators, most of which use diesel fuel and thus aggravate India's oil import problem. In FY 1990 selfproduction accounted for about $8 \%$ of India's total power generation. ${ }^{3}$

\footnotetext{
'The fiscal year in India runs from April 1 to March 31. Years given in the text refer to fiscal years (i.e., FY $1990=1990$ 91) unless otherwise indicated.

${ }^{2}$ Economic Intelligence Service, Current Energy Scene in India, 1992

${ }^{3}$ Economic Times of Bombcy, July 2, 1992.
} 
Power generation in India is divided between central and state units (generation by private utility companies accounts for about $4 \%$ of the overall total). Each state has a State Electricity Board (SEB) in charge of power system maintenance and expansion. SEBs accounted for $74 \%$ of total installed capacity in 1992 (Table 3-2), but the central government has accounted for an increasing share of new capacity (roughly $40 \%$ ) in the past decade. Poor management and the insulation of SEBs from fiscal constraint have resulted in weak financial and institutional performance in most states. SEB proposais for new power plants must be approved by the Planning Commission, and most projects are funded by the central government.

Table 3-1. India Power Sector Statistics"

\begin{tabular}{|c|c|c|}
\hline & FY 1991 & AAGR $^{b}$ \\
\hline Installed Capacity (MW) & $69620(100.0 \%)$ & 7.9 \\
\hline Hydro & $19370(27.8 \%)$ & 4.7 \\
\hline Thermal & $48240 \quad(69.3 \%)$ & 10.0 \\
\hline Nuclear & $2005(2.9 \%)$ & 6.2 \\
\hline Generation (GWh) & $286706(100.0 \%)$ & 9.1 \\
\hline Hydro & $72557(25.3 \%)$ & 4.4 \\
\hline Thermal & $206149^{c}(71.9 \%)$ & 11.7 \\
\hline Nuclear & $8000^{c}(2.8 \%)$ & 7.6 \\
\hline Consumption (GWh) ${ }^{d}$ & $201100(100.0 \%)$ & 8.6 \\
\hline Industrial & $89000(44.2 \%)$ & 5.7 \\
\hline Residential & $31303(15.6 \%)$ & 12.1 \\
\hline Commercial & $22669(11.3 \%)$ & 9.7 \\
\hline Transport & $4499 \quad(2.2 \%)$ & 6.2 \\
\hline Agricultural & $53625(26.7 \%)$ & 13.1 \\
\hline
\end{tabular}

Notes: a. Not including self-producers, who generated on estimated 25,000 GWh in FY 1991.

b. AAGR = Average Annual Growth Rate.

c. Estimated from combined thermal/nuclear total.

d. We estimate consumption statistics based on FY 1990 data.

The central government's power sector institutions include the National Hydroelectric Power Corporation (NHPC), the National Thermal Power Corporation (NTPC) and the National Grid Power Corporation (NGPC) for transmission network expansion. Both the NTPC and NHPC, which were instituted in the late 1970s, have shown substantially better performance records than the SEBs, partly due to better access to financial resources, sources of fuel supply and a newer capital stock. The Department of Power, with advice from the Central Electricity Authority (part of the State Planning Commission), is responsible for electricity planning and policy formulation. The Power Finance Corporation, a semi-governmental entity, provides "soft" loans for power development projects. In theory, the state and central government institutions 
coordinate to determine the best integrated approach to capacity expansion. In practice, however, the Central Electricity Authority has little ability to redistribute poorly allocated resources.

Table 3-2. Installed Capacity in India as of 31 March, 1992 (GW)

\begin{tabular}{lcccccc}
\hline & Northern & Western & Southern & Eastern & North & All India \\
\hline \hline Central Government & 6.8 & 4.2 & 4.2 & 2.9 & 0.3 & 18.4 \\
State Electricity & 13.7 & 17.3 & 13.0 & 6.4 & 0.8 & 51.2 \\
Total Regional & 20.5 & 21.5 & 17.2 & 9.3 & 1.1 & 69.6 \\
\hline \hline
\end{tabular}

Note: Installed capacity for private power generation in India is $2.8 \mathrm{GW}$.

Source: Economic Intelligence Service, Current Energy Scene in India, May 1992.

During India's last five year planning period (FY 1985-1989), the country increased its generating capacity by $21.4 \mathrm{GW}$, nearly meeting the planned capacity increase. ${ }^{4}$ The success rate was far better than in earlier planning periods. As Table 3-3 indicates, shortfalls of between $20 \%$ and $40 \%$ of targeted additions have been more common. Yet, even given this notable increase, India still faced energy shortages that averaged $8 \%$ between 1985 and $1987 .^{5}$

Table 3-3: Plan-wise Slippages in Additional Installed Capacity

\begin{tabular}{lccc}
\hline Plan & Target & Achievement & Slippage (percent) \\
\hline First Plan (1951-55) & 1300 & 1100 & -15.4 \\
Second Plan (1956-60) & 3500 & 2250 & -35.7 \\
Third Plan (1961-65) & 7040 & 4520 & -35.8 \\
Annual Plan (1966-68) & 5430 & 4120 & -24.1 \\
Fourth Plan (1969-73) & 9264 & 4579 & -50.5 \\
Fifth Plan (1974-78) & 12499 & 10202 & -18.4 \\
Annual Plan (1979) & 2945 & 1799 & -38.9 \\
Sixth Plan (1980-84) & 19666 & 14226 & -27.7 \\
Seventh Plan (1985-89) & 22245 & 21402 & -3.8 \\
Annual Plan (1990) & 4212 & 2777 & -34.1 \\
Annual Plan (1991) & 3811 & 3027 & -20.6 \\
\hline \hline
\end{tabular}

Source: Economic Intelligence Service, Current Energy Scene in India, May 1992

4India's power sector plans run according to the Fiscal Year, April-March.

${ }^{s}$ Central Electricity Authority, 8th Power Plan for India (1990-95), September 1991. 


\subsection{Resources for Electricity Generation}

Coal reserves (as of 1992) are listed at 196 billion tons, although only about 125 billion tons may be minable. ${ }^{6}$ In 1991 the power sector consumed 137 million tons (Mt) of coal; estimates of power sector requirements in the year 2000 are $218 \mathrm{Mt}^{7}$

Although the coal resource is large, India's coal seams are mainly located in the eastern and central states, and coal transport has become a serious problem. The distance from coal mines to demand centers and dirt and rock mixed with the coal have substantially increased transportation costs per ton of coal. Shortages of railway wagons have forced some utilities to seek alternative solutions. For example, the Tamil Nadu and Karnakata electricity boards in southern India were granted one-time 30\% duty rates (compared to $85 \%$ normally) in 1992 to import $2 \mathrm{Mt}$ and $1 \mathrm{Mt}$ of coal respectively in order to cope with shortages. ${ }^{8}$ In addition to transport problems, Indian coal has high ash content ( $40 \%$ on average), which leads to frequent downtime for boilers and contributes to poor plant efficiency. India is pursuing fluidized bed combustion to facilitate combustion of this high ash coal.

India has limited oil resources. Recoverable crude oil reserves were estimated at $806 \mathrm{Mt}$ in 1991, up from $738 \mathrm{Mt}$ estimated in 1990. ${ }^{9}$ Production in 1990 was $33 \mathrm{Mt}$, with estimates for 1992 at $27-29$ Mt--over $20 \mathrm{Mt}$ short of India's total consumption. ${ }^{10}$ Oil's relative scarcity makes it less suited for electric generation, and no oil-based thermal plants are being built.

Natural gas holds great potential to reduce India's power generation gap. Gas reserves increased five-fold in the 1980s. Current reserves are approximately 730 billion cubic meters; production in 1990 was about 18 billion $\mathrm{m}^{3} .{ }^{11}$ The lack of an infrastructure to transport the gas to demand centers has resulted in tremendous waste of this valuable resource; in 1990 between 4.4 and 5.5 billion $\mathrm{m}^{3}$ was flared, at a loss of roughly 2,400 crores ( $\$ 934$ million). ${ }^{12}$ Nearly $30 \%$ of India's total gross gas production is currently flared, although with the aid of a

\footnotetext{
${ }^{6}$ Economic Intelligence Service, op cit., Ref. 2.

${ }^{7}$ Sachdev, R.K., Director, Ministry of Coal, paper presented at conference on the Benification of Power Grade Coals: Its Relevance to Future Coal Use in India, 1991.

8 "Foreign extraction: India addresses energy crunch on all fronts," Far Eastern Economic Review, November $12,1992$.

${ }^{9}$ Economic Intelligence Service, op cit., Ref. 2.

10 "Slippery slope-impasse over oit reforms puts India's loans at Risk," Far Eastern Economic Review, June $18,1992$.

${ }^{11}$ Economic Intelligence Service, op cit., Ref. 2.

12 The Hindu, Survey of Indian Industry, 1990. See also Economic Intelligence Service, op cit., Ref. 2. Most of the flared gas is located off the Western coast and could be connected to the adjoining states by a $1200 \mathrm{~km}$ pipeline, but that no such decision has been reached yet (Prof. R.V.G. Menon, College of Engineering, Kerala, personal communication, November 4, 1992).
} 
$\$ 1.1$ billion loan from the World Bank., Asian Development Bank and Japan EXIM Bank, the government hopes to achieve zero flaring by $1993 .{ }^{13}$ The power sector currently consumes about $17 \%$ of available natural gas.

India has considerable hydroelectric resources. The Central Electricity Authority (CEA) estimates that $600 \mathrm{TWh}$ of ge.ierating potential or $84,000 \mathrm{MW}$ of capacity remain untapped (mainly in the north and northeast regions). The problem is that about two-thirds of the hydropower potential is situated in the Himalaya mountain ranges, far from industrial centers. ${ }^{14}$ In addition, the CEA has identified 56 sites for development of pumped storage projects with a potential cajacity of $94,000 \mathrm{MW} .^{15}$

Nuclear generation accounts for only $2.5 \%$ of India's total, but the country has substa ntial uranium reserves (67,000 tons of U308 and 13,000 tons in monazite sands) that could enable it to produce large amounts of nuclear electricity in the future. By one estimate, India could support a nuclear power program of about $8,000 \mathrm{MW} \cdot{ }^{16}$

As for non-hydro renewables, one source estimates that biomass and related renewables could contribute $10,000 \mathrm{MW}$ of power over the next decade. ${ }^{17}$ One estimate places wind power potential alone at the $20,000 \mathrm{MW}$ level..$^{18}$ Better assessment of these non-hydro resources is needed for India's future electricity planning.

\subsection{Forecast of Electricity Demand}

The CEA forecast for the original 8th power plan predicted a peak demand of $91.2 \mathrm{GW}$ and an energy generation requirement of 517 TWh in FY 1999. Using data from the 14th Electric Power Survey of India, the CEA estimated the electricity demand by sector and region, and then aggregated the totals into an all-India figure. Given the radical downward revision of added capacity (see below) and the lack of serious consideration of the potential to improve efficiency, the forecast is solely indicative. Average annual rates of growth in electricity generation for the three five-year periods between FY 1990 and 2004 are $9.4 \%, 7.5 \%$ and $7.0 \%$.

\footnotetext{
${ }^{13}$ Economic Intelligence Service, op cit., Ref. 2.

${ }^{14}$ Gazdar, M.N., India, Asia-Pacific Energy Series, East-West Center, March 1992.

${ }^{15}$ Department of Power (Government of India), presentation materials, April 1992.

${ }^{16}$ Gazdar, M.N., op cit., Ref. 14.

${ }^{17}$ Asian Development Bank, Environmental Considerations in Energy Development, May 1991.

${ }^{18}$ Economic Intelligence Service, op cit., Ref. 2.
} 
Table 3-4: CEA Electricity Demand Forecast - All India

\begin{tabular}{lcc}
\hline & Peak Demand & Energy Requirement \\
\hline \hline FY 1990 & 46.5 & 288 \\
FY 1994 & 63.7 & 360 \\
FY 1999 & 91.2 & 517 \\
FY 2004 & 127.4 & 726 \\
\hline \hline
\end{tabular}

Sou-ne: Central Electricity Authority, Fourteenth Electric Power Survey of India, Department of Power, New Delhi, March 1991.

\subsection{Plans for Power Sector Development}

In April 1992, India formally launched its five-year plan for FY 1992-96. The plans for power sector expansion were a revision of the original plan (for the FY 1990-94 period), which called for an additional 38,000 MW of installed capacity. This target was revised downward twice. More recent (May 1992) information places total capacity additions at 24,468 MW (Table 3-5).

Table 3-5: Revised CEA Estimated Capacity Addition in FY 1992-96 (MW)

\begin{tabular}{|c|c|c|c|c|}
\hline Region & Kydro & Thermal & Nuclear & Total \\
\hline Northern & 2166 & 4433 & 470 & 7069 \\
\hline Western & 1388 & 3560 & 235 & 5183 \\
\hline Southern & 626 & 3359 & 470 & 4455 \\
\hline Eastern & 891 & 5860 & - & 6751 \\
\hline North-Eastern & 325 & 686 & - & 1011 \\
\hline All India & 5396 & 17898 & 1175 & 24468 \\
\hline
\end{tabular}

Source: Department of Power, presentation materials, May 1992.

Thermal plants account for the majority of planned new capacity (73\%), with hydro (22\%) and nuclear (5\%) accounting for the remainder. Coal-fired generation is expected to grow at a slower rate than in the past decade, with a large part of the coal-plant expansion planned for a chain of large mine-mouth plants in the Singrauli region, near coal resources. ${ }^{191}$ A key change from the past is that about one-fourth of the planned thermal capacity (4652 MW) is gasbased projects. The northern and western regions account for most of the new hydro capacity. The CEA plans do not include statistics on plant retirement. Based on our estimate the proiected total installed capacity at the end of FY 1996 is around 93 GW (Table 3-6) (Figure 3-1).

\footnotetext{
${ }^{19}$ Gazdar, M.N. op cit., Ref. 14.
} 


\section{India Power Development Plans Installed Capacity}

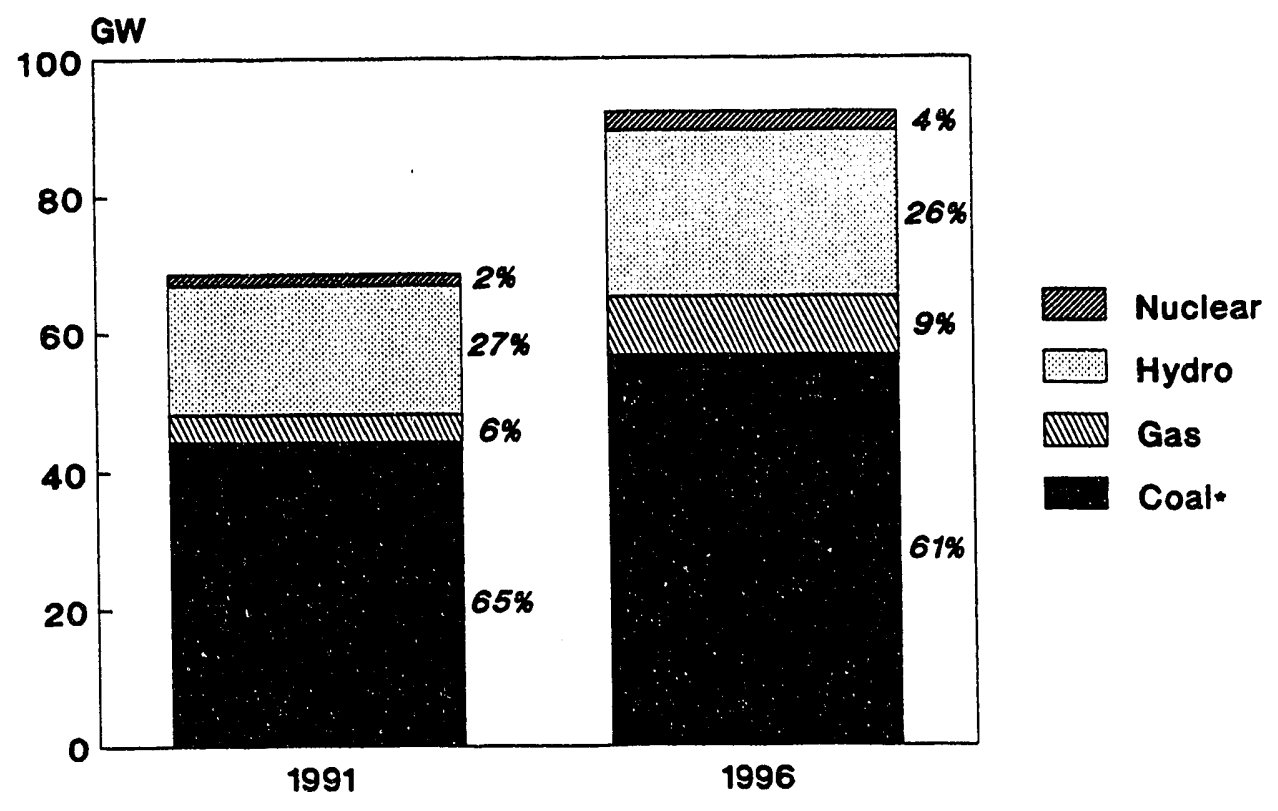

- includes small amount of diesel

Figure 3-1 
The revised capacity plans reflect a more achievable goal, given the limited capital for investment and construction delays. However, even this revised estimate may be too optimistic, because some of the new hydro additions planned for the northern and western regions will probably be delayed due to intense domestic opposition to dam projects and the loss of lenient Soviet aid packages for dam construction. ${ }^{20}$ For example, the Sardor Sarovar dam, a \$1.13 billion, 1200-MW project, has repeatedly been halted due to disagreements over the reimbursement for the displacement of the local population. ${ }^{21}$ However, the World Bank has indicated that it will continue funding the Sardor dam and other Narmada river projects on the condition that environmental and resettlement targets set in the Bank's action plan are met. World Bank funding for the projects is slated at $\$ 450$ million. ${ }^{22}$ Even if the revised targets are met, shortages are likely to continue. In the original Plan, authorities predicted peak shortages of at least $15 \%$ on an all-India basis, although the basis for that estimate is not clear.

Table 3-6: Projected Installed Capacity - All India (GW)

\begin{tabular}{|c|c|c|c|c|c|}
\hline & Hydro & Coal" & Gas & Nuclear & Total \\
\hline FY 1991 (actual) & $19.4(28 \%)$ & $44.3(64 \%)$ & $3.9(6 \%)$ & $2.0(3 \%)$ & $69.6(100 \%)$ \\
\hline $\begin{array}{l}\text { Estimated retirement of } \\
\text { installed } 1991 \text { capacity }^{b}\end{array}$ & 0 & $2 \%$ & 0 & 0 & -0.8 \\
\hline $\begin{array}{l}\text { Capacity additions } \\
(1992-1996)\end{array}$ & 5.4 & 13.2 & 4.7 & 1.2 & 24.5 \\
\hline FY 1996 total & $24.8(27 \%)$ & $56.6(61 \%)$ & $8.6(9 \%)$ & $3.2(3 \%)$ & $93.2(100 \%)$ \\
\hline
\end{tabular}

Notes: a. We have estimated the split of thermal into coal and gas. Coal includes diesel plants and gas turbines.

b. Retirement of thermal plants based on historical retirements during the $1980 \mathrm{~s}$.

The current plans call for an 1175-MW increase in nuclear generating capacity despite the fact that India's nuclear power is not a least-cost source of electricity. The nuclear power program has been heavily subsidized, since the country's focus has been on the development of indigenous capacity and the domestic manufacture of components. One reason for this approach is to avoid the IAEA oversight that accompanies the import of foreign generating technology and the generation of plutonium. Recently, India has come under increasing pressure by the major western powers to sign the non-proliferation treaty and bring its nuclear program under international inspection. ${ }^{23}$ Given the high costs of nuclear plants, the government is considering

\footnotetext{
20 "Soviet collapse endangers Indian [hydro] power projects," The New York Times, April 12, 1992.

21 "Dam under fire," Far Eastern Economic Review, July 2, 1992; "India dam project brings a quandary; New Delhi seeking influence on environmental issues," New York Times, June 2, 1992. As of early 1993, however, the Indian government had stated it would proceed with the project without loan funds from the World Bank.
} 
the redirection of some 8th Plan funds to natural gas development, although no firm decision has been made in this regard. ${ }^{24}$

In terms of renewable and non-conventional energy sources for electricity generation, the Department of Non-Conventional Energy Sources in the Ministry of Power hopes to expand nonconventional input to $15 \mathrm{GW}$ by the year $2000 .{ }^{25}$ Although this projection appears to be overly ambitious, some non-conventional sources hold much potential. India currently has $38 \mathrm{MW}$ of wind-generating capacity and plans further expansion. The province of Tamil Nadu, with a current capacity of $19 \mathrm{MW}$, holds some of the country's best wind resources and is a good candidate for future expansion. ${ }^{26}$

Renovation of existing plants is an important component of India's power sector strategy. A large-scale renovation program was started in the mid-1980s, and early plans estimated an expenditure of about Rs. 3000 Crores ( $\$ 1.17$ billion) for the FY $1992-96$ period. However, the States are being called upon to generate most of these funds, leaving open the possibility of funding shortfalls for resource-strapped state governments. The renovations envisioned during FY 1992-96 would add an additional 1,600 MW of capacity and improve the plant load factor for affected power stations to $58 \%$ from their current $53 \%$ level. One source estimates that a one percentage point improvement in the all-India plant load factor would provide an additional $500 \mathrm{MW}$ of power. ${ }^{27}$ About Rs. 8000 Crores (\$3.11 billion) will be allocated for R\&D for improvement of thermal plant availability and coal utilization and for increasing the efficiency of hydro technology.

\section{Private Sector Participation}

Given the financial constraints of public utilities, the government has come to place greater emphasis on private sector participation. In June 1990, the government announced a new policy which amends existing laws to encourage private generation for sale to the grid. Under the new law, private firms can set up coal/lignite, gas-based, or hydroelectric projects of any size either as licensees of the state or as generating companies. They may subsequently generate and sell power to the State Electricity Boards for distribution. Some of the incentives for participation include: 1) private companies can maintain a debt/equity ratio of up to $4: 1$, with no more than $40 \%$ of total outlay coming from the Indian public sector financial institutions; 2 ) $100 \%$ foreign equity is permitted; 3 ) a $5 \%$ rather than $2 \%$ rate of return above the central bank indicator rate (or currently, a $16 \%$ post-tax return on capital invested); 4) the establishment of an investment promotion cell in the Department of Power to provide project identification and

\footnotetext{
${ }^{24}$ R.V.G. Menon, personal communication, November 4, 1992.

${ }^{25}$ Gazdar, M.N., op cit., Ref. 14.

${ }^{26}$ Economic Intelligence Service, op cit., Ref. 2.

${ }^{27}$ Ibid.
} 
an expedited "single window clearance"; and 5) the allowance of a two-part tariff structure to cover both fixed and variable costs. ${ }^{28}$

In May 1992, the government reported that the new policy to encourage private sector participation had resulted in around $9000 \mathrm{MW}$ of hydro and thermal project proposals, some of which will contribute to the $5000 \mathrm{MW}$ private sector additions called for in the revised 8th plan. ${ }^{29}$ How many of these projects will come to pass is uncertain, but the prospects were looking encouraging as of early 1993. For example, the Enron Corporation of the U.S. has signed an agreement with the Maharashtra State Electricity Board (MSEB) to set up $1900 \mathrm{MW}$ of natural gas-fired power plants (to be fueled by LNG imported from the Middle East). MSEB will guarantee a price of Rs. 2.3 (8 US cents) per $\mathrm{kWh}$ for power purchased from these power plants. The Indian government will bear the risk of repatriating Rs. 250 crores (US $\$ 300$ million) of hard currency for imported natural gas. ${ }^{30}$ A number of other projects are in advanced stages of negotiation.

\subsection{Financial Issues}

In India's last three five-year plans, power sector outlays accounted for nearly $20 \%$ of total public investment. For FY 1992-96, an estimated Rs. 78,000 crores ( $\$ 30$ billion) of public investment will be needed to meet the $24,000 \mathrm{MW}$ target, with hoped for private sector investment expected to account for another Rs. 15,000 crores ( $\$ 5.8$ billion). ${ }^{31}$

Raising the needed public investment may prove difficult, as India has been plagued by poor financial performance in its utility sector. The State Electricity Boards (SEBs) have consistently run large commercial losses. ${ }^{32}$ The losses are incurred for a variety of reasons, but a key factor is that electricity tariffs do not cover the average cost of supply. This is especially problematic in the agricultural sector, where heavily subsidized rates lead to losses of roughly Rs. 3720 ( $\$ 1.4$ billion) annually; ${ }^{33}$ SEB compensation from the central government for the losses from rural electrification are only $50-60 \%$ of the actual losses. Net SEB losses for FY 1990, after accounting for central government subsidies, still ran Rs. 1390 crores (\$540

\footnotetext{
${ }^{23}$ Economic Times Bombay, op cit., Ref. 3.

${ }^{29}$ Department of Power, op cit., Ref. 15.

30 "First foreign power project OK'd," India Abroad, January 8, 1993.

${ }^{31}$ Economic Intelligence Service, op cit., Ref. 2.

32 Because many SEBs were in arrears to Coal India Ltd. (the country's coal production company), a system was implemented in 1991 where coal was delivered only against advanced payments.

${ }^{33}$ Central Electricity Authority, op cit., Ref. 5.
} 
million). ${ }^{34}$ Aside from tariff reform, other means for making SEBs more financially viable include the development of more orderly approaches for planning distribution systems, and the improvement of metering for revenue collection. Poor SEB performance has resulted in a rapid down-scaling of multilateral loans for the power sector. The CEA has suggested that arranging for quicker transfers of state subsidy payments for rural electrification to the SEBs would improve their financial position, but this mechanism does not address the structural and management reforms needed to induce profitability in the SEBs.

\subsection{Environmental Considerations}

Coal-based thermal generation is accompanied by a number of negative effects, including atmospheric pollution and ash disposal. As part of its approach to improve environmental quality, the Indian government has set emission standards on particulate emissions (Table 3-7).

\begin{tabular}{|c|c|}
\hline \multicolumn{2}{|l|}{ Boilers } \\
\hline less than $210 \mathrm{MW}$ & $350 \mathrm{mg} / \mathrm{m}^{3}$ \\
\hline greater than $210 \mathrm{MW}$ & $150 \mathrm{mg} / \mathrm{m}^{3}$ \\
\hline \multicolumn{2}{|l|}{ Stack Heights } \\
\hline $200 \mathrm{MW}$ & $220 \mathrm{Mt} / \mathrm{yr}$ \\
\hline $500 \mathrm{MW}$ & $275 \mathrm{Mt} / \mathrm{yr}$ \\
\hline
\end{tabular}

Source: Department of Power, presentation, India, April 1992.

For the implementation of pollution control standards, the Central Pollution Control Board (CPCB) and 20 state boards are responsible for the monitoring of emission levels. ${ }^{35}$ Power sector emissions also are regulated by other Ambient Air Quality requirements under the Environment (protection) Act.

The negative ecosystem effects from hydropower development are beginning to emerge with greater clarity. These include the potential for increased geological instability (erosion, etc.), seepage and changes in the tectonic strain level and sedimentation. ${ }^{36}$ Surveys by the

\footnotetext{
${ }^{34}$ Only five state electricity boards--Andhra Pradesh, Madhya Pradesh, Maharashtra, Tamil Nadu, and Uttar Pradesh-made a profit in FY 1990. However, only two achieved the legally mandated target of 3\% of net fixed assets less consumers' contributions at the beginning of the year. Economic Intelligence Service, op cit., Ref. 2.

${ }^{3 s}$ Asian Development Bank, op cit., Ref. 17.

${ }^{36}$ Guha, S.K., "Environmental impacts of hydropower generation with special reference to Koyna hydroelectric project, Maharashtra, India," Energy Environment Monitor 6:1-16, September, 1990. The study found that the dam construction created a local ecological imbalance by destroying habitat, and found a high correlation of reservoir induced seismicity.
} 
Central Water Commission have noted higher rates of sedimentation behind dams than originally expected, resulting in a loss of reservoir capacity of $0.5 \%$ to $1.2 \%$ per year. ${ }^{37}$

Aside from regulation and monitoring, the government has assigned the Ministry of Environment and Forests in India the task of reviewing the Environmental Impact Statements and Environmental Management Plans that are required for new thermal and hydro power projects. As part of the approval process for new hydroelectric and thermal generation projects, the Ministry issues environmental guidelines and has the power to not concur if the environmental impact statements are not thorough. This has already resulted in the delay of several hydro proposals for development. ${ }^{38}$

The power sector is a principal contributor to India's $\mathrm{CO}_{2}$ emissions, which account for $5 \%$ of the world total. It accounts for about 33\% of India's carbon emissions from fossil fuels. $^{39}$

\subsection{Electricity Supply and End-Use Efficiency}

Even if the target for additional capacity is reached, shortfalls of power supply are still expected. The government has proposed a number of measures to encourage electricity end-use efficiency and to improve supply efficiency as a means of reducing the shortage.

On the supply side, an ongoing renovation and modernization program is underway to improve generation efficiency. There are efforts to reduce auxiliary consumption, which is very high, and to improve the efficiency of thermal power stations. Transmission and distribution (T\&D) losses are considerably higher than those in many other developing countries, and rose from $21.5 \%$ in 1984 to $23 \%$ in 1989. Part of the problem lies in the loss of power from theft and the lack of adequate metering and revenue collection, but the installation of capacitors to lessen losses from reactive power can reduce line losses.

The government has begun to consider end-use efficiency policies as well. A recent study characterized the potential for electricity end-use efficiency improvement in India. ${ }^{40}$ It looked at 27 measures in industry, buildings and agriculture, and estimated that they could reduce electricity use in 2005 by approximately $20 \%$. The largest savings are in electric motors, high-efficiency pumpsets and conversion from incandescent to fluorescent fixtures (Table 3-8). The study estimated that the measures would require an investment of about $20 \%$ (on average) of the cost of new supply to deliver the same level of electricity service. Even the most

\footnotetext{
${ }^{37}$ Asian Development Bank, op cit., Ref. 17.

38 Ibid.

${ }^{39}$ Indira Gandhi Institute of Development Research, "Climate Change and India's Energy Policy Options," February 1992.

${ }^{40}$ Nadel, S., V. Kothari, and S. Gopinath, Opportunities for Improving End-Use Electricity Efficiency for India (Washington, D.C.: American Council for an Energy-Efficient Economy), 1991.
} 
expensive of the measures has a lower cost per $\mathrm{kWh}$ saved than the short-run marginal cost of electricity production, and a lower cost per $\mathrm{kW}$ of reduced demand than the capital cost of new baseload generating capacity. Inclusion of additional measures or allowing more time for penetration would increase the savings potential. Another study estimated that replacing $20 \%$ of the incandescent lighting market (which makes up $17 \%$ of the country's electricity consumption) with compact fluorescent bulbs could save $\$ 6.4$ billion in the cost of avoided capacity investments. $^{41}$

Table 3-8. Potential Electricity Savings from Selected End-Use Efficiency Measures in India

\begin{tabular}{lc}
\hline \hline Measure & Percent of Projected GWh Sales, 2005' \\
\hline \hline Variable speed drives & 2.22 \\
Motor rewinding, etc. & 2.04 \\
High-efficiency new pumpsets & 1.81 \\
Incandescent to fluorescent fixture & 1.64 \\
Agricultural pumpset rectification & 1.59 \\
Electronic ballast & 1.49 \\
Meter agricultural pumpsets & 0.80 \\
High efficiency motors & 0.77 \\
Two-speed motors & 0.76 \\
High-efficiency refrigerator & 0.73 \\
Improved aluminum smelters & 0.67 \\
TLD lamp & 0.66 \\
Compact fluorescent lamp & 0.66 \\
Moderate-efficiency refrigerator & 0.65 \\
Optimize industrial pumps & 0.62 \\
Other measures & 3.77 \\
Total & 20.88 \\
\hline \hline
\end{tabular}

Note: a. Projected sales are 501 TWh (low case) and 802 TWh (high case).

Source: Nadel et al. (1991).

The government recently announced its intention to achieve a $5000 \mathrm{MW}$ reduction in power demand by $1997 .{ }^{42}$ This would amount to about $6 \%$ of projected peak power demand. Since $75 \%$ of electricity consumption falls in the agricultural and industrial sectors (especially in energy-intensive industries such as aluminum, steel, cement and paper), government planners see the key to reducing load growth in policies such as compulsory industrial energy audits, and introducing more efficient agricultural pumps, as well as promoting policies which encourage structural change in inefficient, energy-intensive industries. Load management and time-of-day pricing are also being considered to both spread out and lessen the overall load.

\footnotetext{
${ }^{41}$ Sathaye, J. and A. Gadgil, "Aggressive cost-effective electricity conservation," Energy Policy, February 1992.

${ }^{42}$ Asian Energy News, September 1992.
} 
The National Productivity Council (NPC), which has been active in energy conservation for many years, is studying the establishment of energy consumption norms for electric motors, industrial pumps, fans, blowers and textile machinery. The NPC is also conducting a study aimed at improving the manufacture of agricultural pumpsets in the small industrial sector.

Although there has not been a comprehensive demand-side strategy articulated, the Maharashtra SEB, based in Bombay, is planning to implement DSM activities in a variety of sectors as a way of addressing its peak power shortage. It has conducted audits of industrial customers in its service area and developed preliminary DSM program plans. The plans were based on an evaluation of electricity consumption in eight end-uses..$^{43}$ In each case, the cost of conserved electricity, including the administrative costs, was estimated to be significantly less than the marginal tariff of Rs. 3 per kWh. A total savings potential of $500 \mathrm{MW}$ was identified. A few other SEBs are beginning to express interest in broadening DSM activities beyond the realm of load management.

\subsection{Conclusion}

The Indian government hopes to add some $24 \mathrm{GW}$ of installed capacity in the FY 199296 period. If this target is met, the total capacity in mid-1997 would amount to around $90 \mathrm{GW}$, of which two-thirds would be thermal capacity. Because of constraints to hydro development, some three-fourths of the new capacity will be thermal. While most of that will be coal-fired, the government and state electricity boards are making efforts to increase the role of natural gas. While gas-fired plants have lower capital costs per installed $\mathrm{kW}$ and the use of combined-cycle power plants permits high efficiency, domestic gas supplies are insufficient. If large-scale LNG imports are allowed, gas could play a greater role than now envisioned, but shortage of hard currency is a constraint.

Lack of capital could make it difficult for India to meet its targets for capacity expansion. Recognizing this potential barrier, the government has enacted a number of measures designed to attract private sector investment in power projects and to encourage industrial cogeneration. A number of private projects are in advanced stages of negotiation, and it appears that the new policy will result in considerable power supply from the private sector.

Even if India manages to meet its targets for capacity expansion, it will likely face continuing electricity shortages. The government and at least one state electricity board are beginning to take a serious interest in demand-side management. The potential is great, but improper electricity pricing (especially subsidies for agricultural pumping) and institutional weaknesses are problem areas. The combination of equipment standards at the national level with DSM programs and pricing reform at the state level could have a considerable impact on demand by the late 1990s.

\footnotetext{
${ }^{43}$ The end-use measures included: energy efficient motors replacement, variable speed drives, waste heat driven by absorption chillers, retrofitting electric arc furnaces, replacing $250 \mathrm{~W}$ high-pressure mercury vapor lamps by 150 W high-pressure sodium vapor lamps, replacing magnetic ballast with electronic ballast, replacing incandescents by compact flourescents (Indira Gandhi Institute of Development Research, Draft Study on DSM potential for the MSEB).
} 


\section{INDONESIA}

\subsection{Introduction}

Perusahaan umum Listrik Negara (PLN), a state-owned utility, has been responsible for Indonesia's public electricity supply since 1961. Due to rapid growth in electricity demand, continual capital shortages and difficulties associated with providing services to remote areas, PLN historically has satisfied only a portion of the nation's overall power needs. Many Indonesian industries have come to rely on captive power plants (private generators purchased by individual industries) to meet their demands. ${ }^{2}$ Similarly, some isolated villages not serviced by PLN draw electricity from local cooperatives. As of FY $1990,{ }^{3}$ PLN accounted for about two-thirds of Indonesia's total electricity generation. ${ }^{4}$

Indonesia's geography has shaped the structure of the power sector. Approximately 3,000 of the nation's 13,000 islands are significantly inhabited, but most of the population of 180 million can be found on four main islands. Java, the most populated of these islands, is home to about $60 \%$ of the population, but accounts for less than $10 \%$ of the national land mass. Due to the dispersion of the population requiring electricity services and the unequal distribution of the domestic energy resources, Indonesia has a highly decentralized power sector with the dominant power sources varying considerably from island to island.

Electricity consumption in Indonesia has soared over the past decade. Between 1980 and 1990 , public electricity sales grew at an average rate of $15.6 \%$. GDP grew far more slowly, averaging $5.5 \% /$ year. The industrial sector witnessed particularly high growth rates, averaging almost $24 \%$ per year throughout the 1980 s.

Indonesia has an enormous natural resource base, which includes substantial quantities of oil. Oil's contribution to electricity generation hit a peak of $77 \%$ in 1982 . In order to free up as much of the domestic oil supply for export purposes as possible, the government has since diversified the nation's power base, leading to a substantial decline in oil's share in the electricity-generating mix. Nonetheless, Indonesia's dependence on oil for electricity generation still remains high. In 1990, oil's share in electricity generation stood at $46 \%$ (Table 4-1). The introduction of coal and gas into the mix in the mid-1980s helped alleviate some of the demand for oil. Coal accounted for a $28 \%$ share of generation in 1990 and natural gas accounted for a $4 \%$ share. In addition, over the past decade the utility stepped up the use of hydro and geothermal, which comprised $16 \%$ and $3 \%$ shares of the electricity-generating base respectively in 1990.

\footnotetext{
' Unless otherwise noted, the background data were drawn from Perusahaan Umum Listrik Negara (PLN), PLN Statistics 1990/91, 1991.

2 In FY 1990 electricity generation from captive power plants was reported to be $14,300 \mathrm{GWh}$ (PLN planning documents 1992).

${ }^{3}$ The fiscal year extends from April - March (e.g., FY $1990=$ April 1, 1990 - March 31, 1991). Throughout this section, the data refer to the fiscal year.

- This study focuses primarily on the public power supply provided by PLN.
} 
PLN had an installed generating capacity of 9119 MW at the end of FY 1990. Thermal sources accounted for about three-quarters of this total. Steam-fired plants dominate the thermal base, followed by diesel facilities and, on a much smaller scale, gas-turbine plants. ${ }^{5}$ Hydro plants comprise most of the remaining capacity, aside from $140 \mathrm{MW}$ of geothermal capacity (which equals about $1.5 \%$ of total installed capacity).

Table 4-1. PLN Installed Capacity, Electricity Generation and Sales, FY 1990

\begin{tabular}{|c|c|c|}
\hline & FY 1990 & $\begin{array}{c}\text { AAGR } \\
\text { FY 1980-FY } 1990\end{array}$ \\
\hline Installed Capacity (MW) & $9119(100.0 \%)$ & $13.6 \%$ \\
\hline Hydro & $2095(23.0 \%)$ & $18.7 \%$ \\
\hline Thernal & $6884(75.5 \%)$ & $12.2 \%$ \\
\hline Steam & $3941(43.2 \%)$ & $18.0 \%$ \\
\hline Diesel & $1870(20.5 \%)$ & $1.8 \%$ \\
\hline Gas Turbine & $1073(11.8 \%)$ & $13.6 \%$ \\
\hline Geothermal & $140 \quad(1.5 \%)$ & a \\
\hline Electricity Generation (GWh) & $34879(100.0 \%)$ & $15.3 \%$ \\
\hline Hydro & $5675(16.3 \%)$ & $15.5 \%$ \\
\hline Thermal & $27212(78.0 \%)$ & $16.0 \%$ \\
\hline Coal $^{b}$ & $9837(28.2 \%)$ & c \\
\hline $\mathbf{O i l}^{b}$ & $16087(46.1 \%)$ & $10.1 \%$ \\
\hline Gas $^{b}$ & $1288 \quad(3.7 \%)$ & c \\
\hline Geothermal & $1125 \cdot(3.2 \%)$ & a \\
\hline Purchase & $867(2.5 \%)$ & $-0.6 \%$ \\
\hline Electricity Sales (GWh) & $27741(100.0 \%)$ & $15.6 \%$ \\
\hline Industry & $14166(51.1 \%)^{d}$ & $23.5 \%$ \\
\hline Residential & $9004(32.5 \%)$ & $12.0 \%$ \\
\hline Commercial & $4571(16.5 \%)$ & $9.1 \%$ \\
\hline
\end{tabular}

Notes: a. PLN's first geothermal capacity came on line in 1982.

b. Estimated based on fuel use.

c. Coal and gas were first introduced into the generating mix in 1985.

d. Including self-production, the industrial sector consumes about $70 \%$ of Indonesia's power generation.

Sources: Perusahaan Umum Listrik Negara (PLN), PLN Statistics 1990/91, 1991.

\footnotetext{
s Gas turbine facilities accounted for about 12\% of PLN's installed capacity in 1990, down from 35 percent in 1980.
} 
Java and Bali, two islands linked by an interconnected grid system, currently account for about two-thirds of PLN's installed capacity and for about four-fifths of PLN's electricity generation. These two islands draw the vast majority of their electricity from steam-fired facilities. ${ }^{6}$ In contrast, Indonesia's more remote islands rely heavily on small-scale diesel-fired generation, a relatively expensive and inefficient option.

While Indonesia has witnessed phenomenal growth in electricity demand, the share of the population with access to electricity continues to remain quite low (at about 33\%). As of 1990, electricity was available to only $54 \%$ of urban households and $13 \%$ of rural households. ${ }^{7}$ Electricity consumption per capita in Indonesia, estimated at about $229 \mathrm{kWh}$ in 1990, remains well below levels found in neighboring Asian countries. ${ }^{8}$

Even with these low levels of electrification and per capita consumption, the Indonesian power sector has been plagued by the threat of severe shortages in recent years. Despite considerable growth in capacity, the suppressed electricity demand far outstrips the available supplies. Between 1985 and 1990, the number of customers connected to the PLN grid rose from 5.9 million to 11.5 million. PLN continues to maintain a lengthy list of unelectrified households eager to gain access to electricity. For industries the waiting period for grid connections has been known to reach up to five years.

In 1991, hydroelectric production fell as a result of a protracted period of low rainfall, which worsened the existing problems. PLN has responded to recent shortages with rolling blackouts in Java and increases in electricity tariffs. The utility also attempted to deflect some of the pressure by promoting self-generation by industries. The government facilitated the proliferation of captive power among industrial and residential users by easing licensing requirements and dropping import duties on diesel-generating sets. In addition, the utility set limitations on grid connections for electricity users that already possessed captive capacity. ${ }^{9}$

\subsection{Resources for Electricity Generation}

Indonesia has a broad array of energy resources -- and many in abundant supply.

Proven oil reserves are estimated at 11 billion tons. In late 1991, production levels of crude oil and condensate averaged 1.6 million barrels per day. Domestic consumption of crude

\footnotetext{
6il-, coal-fired and hydro plants meet the bulk of the baseload demand in the Java/Bali system. PLN aiso uses hydro to satisfy peak demand.

'American Embassy, Indonesia's Electric Power Sector, Jakarta, January 1992.

In contrast,electricity consumption per capita averaged about $770 \mathrm{kWh}$ in Thailand in 1991 and about $2200 \mathrm{kWh}$ per capita in South Korea in 1990.

${ }^{9}$ American Embassy, op cit., Ref. 7.
} 
oil accounts for about half of the production. ${ }^{10}$ Proven and potential reserves of natural gas are estimated at 101 trillion cubic feet. Historically, Indonesia has focused on exporting liquefied natural gas (LNG), as opposed to channeling the huge reserves towards domestic uses.

Indonesia's reserves of bituminous and sub-bituminous coal stand at about 31 billion tons. Proven coal reserves total 3.5 billion tons. ${ }^{11}$ Due to its high moisture content, a large portion of the coal has a low calorific value. However, much of Indonesia's coal is also characterized by low levels of sulfur and ash. Current projections show coal production rising from over 13 million tons in 1991 to 50 million tons in $2000 .^{12}$

With theoretical hydropower resources estimated at 76,000 MW, Indonesia has only just begun to tap into the potential for generating electricity from hydro sources. However, the majority of the untapped hydro potential is located on islands far from Indonesia's population centers, thereby limiting the possibilities of exploiting the resource base. ${ }^{13}$

Indonesia's vast geothermal resources have been variously estimated at $10,000 \mathrm{MW}^{14}$ and $16,000 \mathrm{MW},{ }^{15}$ but much of the resource base lies in remote sites and/or in dense jungles. At least 5,500 MW of this potential lies on the main island of Java. To date, a minimal portion of the geothermal potential has been tapped.

Despite its healthy resource endowment, Indonesia still faces some obstacles on this front, including the location of many of the electricity-generating resources at sites far from the more populous islands. In addition, based on the low levels of electricity consumption and the staggering projections for future growth in domestic energy demand, some observers argue that Indonesia's indigenous resource base quickly could be depleted. According to this outlook, net imports of oil could be required by the twenty-first century. ${ }^{16}$

\subsection{Forecast of Electricity Demand ${ }^{17}$}

\footnotetext{
${ }^{10}$ Prawiraatmadja, W., Yamaguchi, N. and Breazeale, K., Indonesia: Asia Pacific Energy Series Country Report, Resources Programs, EastWest Center, April 1991; American Embassy, op cit., Ref. 7.

"Prawiraatmadja et al., op cit., Ref. 10.

12 American Embassy, op cit., Ref. 7.

13 Prawiraatmadja et al., op cit., Ref. 10.

14 Prawiraatmadja et al., op cit., Ref. 10.

is American Embassy, op cit., Ref. 7.

${ }^{16}$ Prawiraatmadja et al., op cit, Ref. 10

${ }^{17}$ Unless otherwise noted, the data in this section are drawn from Perusahaan Umum Listrik Negara (PLN), PLN's Demand Forecast Model Version DKI 2.0, August 1992.
} 
PLN has developed two forecasts of Indonesian electricity demand for the years 1992 through 2002. In both scenarios, the Indonesian population grows by $1.7 \%$ per year between 1992 and 2003 . GDP expands by $6.9 \%$ per year in the high scenario versus $6.3 \%$ per year in the moderate scenario. ${ }^{18}$ Both scenarios assume that the same growth rates in electricity demand occur in the areas outside of Java and Bali. The government pians to continue promoting rural electrification, which partially accounts for the rapid expansion of electricity consumption in outlying regions. Both scenarios show $63 \%$ of the households outside of Java and Bali with access to electricity by 2003 .

The difference between the scenarios lies in the outlook for the Java and Bali regions. The shares of Javanese, and Balinese households with access to electricity rises to just under $99 \%$ by 2003 airording to the high scenario. In contrast, the moderate scenario foresees the share of electrified households rising to only $75 \% .^{19}$

In the high scenario, electricity sales increase over six-fold between 1990 and 2003, reaching 139 TWh (Table 4-2). Java and Bali witness slightly faster growth (15.1\%/year) than other areas $(14.1 \%$ /year). Public electricity consumption booms in the industrial sector, pushing industry's share of electricity sales from $51 \%$ in 1990 to $64 \%$ in $2003 .^{20}$

In the moderate scenario, PLN sales expand by a factor of about 4.5, reaching $125 \mathrm{TWh}$ in 2003. Java and Bali witness far slower growth in demand (11.8\%/year). PLN electricity sales in the Java/Bali region expand four-fold, as opposed to the six-fold increase that takes place in the high scenario.

The electricity growth rates projected in the high scenario represent a continuation of the levels of growth witnessed in the public power sector over the past two decades. The moderate scenario, however, assumes a considerable slowdown relative to past trends. In both cases, the tremendous gap that existed between the growth rates of electricity demand and GDP during the 1980s narrows slightly.

Unexpectedly high growth of power demand in the past few years forced PLN to revamp the 1989-94 development plan to incorporate $1000 \mathrm{MW}$ of additional installed capacity. ${ }^{21}$ (Actual electricity sales increased by almost $17 \%$ in 1990.) Recently, PLN increased the long-

\footnotetext{
14 GDP growth is fastest in Java \& Bali at $7.8 \% /$ year in the high scenario and $7.2 \%$ /year in the moderate scenario. Value added growth in the industrial and commercial/public sectors average $12.0 \% /$ year and $7.4 \% /$ year respectively in the high scenario. In the moderate scenario, industrial and commercial/public value added growth average $11.4 \% /$ year and $6.75 /$ year respectively.

${ }^{19}$ Together the household and commercial sectors gain 2.3 million new customers per year in the high scenario and 1.7 million new customers per year in the moderate scenario.

${ }^{20}$ Part of the reason for this substantial increase in industrial electricity use is that PLN plans to reconnect some industries currently served by small, inefficient captive power sets onto the grid. These "captive takeovers" shift a number of former non-PLN industrial electricity users to the PLN system.

${ }^{21}$ American Embassy, op cit., Ref. 7.
} 
term electricity generation projection for 2003 (by about 5,400 GWh). Whether actual increases in electricity demand will continue to exceed planners' expectations remains to be seen.

Table 4-2. Projections of PLN Electricity Sales (GWh), FY 1990-FY 2003

\begin{tabular}{lccc}
\hline \hline & FY 1990 & FY 2003 & $\begin{array}{c}\text { AAGR } \\
\text { FY 1990 - FY 2003 }\end{array}$ \\
\hline High Scenario & & & \\
Java \& Bali & 22402 & 138761 & $15.1 \%$ \\
Other areas" & 5339 & 29722 & $14.1 \%$ \\
Total & 27741 & 168483 & $14.9 \%$ \\
Residential & $32.4 \%$ & $20.6 \%$ & $10.9 \%$ \\
Industrial & $51.1 \%$ & $64.2 \%$ & $16.9 \%$ \\
Commercial & $8.4 \%$ & $8.1 \%$ & $14.6 \%$ \\
Other & $8.1 \%$ & $7.1 \%$ & $13.8 \%$ \\
Moderate Scenario & & & $10.4 \%$ \\
Java \& Bali & 22402 & 95628 & $11.8 \%$ \\
Other areas" & 5339 & 29722 & $14.1 \%$ \\
Total & 27741 & 125350 & $12.3 \%$ \\
Residential & $32.4 \%$ & $26.2 \%$ & $10.5 \%$ \\
Industrial & $51.1 \%$ & $59.8 \%$ & $13.7 \%$ \\
Commercial & $8.4 \%$ & $6.4 \%$ & $11.4 \%$ \\
Other & & & $10 \%$ \\
\hline \hline
\end{tabular}

Notes: a. Only the Java \& Bali figures differ under the two scenarios.

\subsection{Plans for Power Sector Development ${ }^{22}$}

PLN's power development plan for 1992 through 2003 continues to emphasize a move away from oil-fired generation. Over the coming decade, PLN plans to rely more heavily on coal-fired generation and, to a lesser degree, on combined-cycle, hydro and gas-turbine generation.

According to both scenarios, the bulk of the additional installed capacity takes place in the Java/Bali region (Table 4-3). New coal plants account for 57\% oí the capacity increase in the high scenario and for $50 \%$ in the moderate scenario. Combined-cycle plants comprise the next largest area of capacity growth -- making up a $20 \%$ share of the new generating base in the high scenario and a $29 \%$ share in the moderate scenario. The construction of combined-cycle

2 Unless otherwise noted, the data in this section are drawn from PLN Plan:ing Documents 1992. 
units represents a concerted effort on the part of PLN to utilize more of Indonesia's considerable gas reserves for electricity generation. The high efficiency of combined-cycle generation also has influenced PLN's plans.

The areas outside of Java and Bali account for only $28 \%$ of the capacity growth in the moderate scenario and $20 \%$ of the growth in the high scenario. Hydro comprises more than half of the additional installed capacity in these areas. Coal and combined-cycle plants both proliferate more rapidly than diesel-fired facilities.

Indonesia's total electricity generation rises from 35 TWh in 1991 to $198 \mathrm{TWh}$ in the high scenario and to $147 \mathrm{TWh}$ in the moderate scenario. The total installed generating capacity for all of Indonesia rises from $9.2 \mathrm{GW}$ to $42 \mathrm{GW}$ in the high scenario and $32 \mathrm{GW}$ in the moderate scenario. Compared to the moderate scenario, the high scenario includes $6800 \mathrm{MW}$ of additional coal-fired capacity, $2640 \mathrm{MW}$ additional gas-turbine capacity and $80 \mathrm{MW}$ more geothermal capacity -- all located in Java and Bali (Table 4-3).

These additions lead to a considerable shift in the electricity-generating base. By 2003, coal comes to dominate the power mix -- accounting for $44 \%$ of installed capacity in the high scenario and $36 \%$ in the moderate scenario (Table 4-4) (Figure 4-1). Combined-cycle plants also take on a significant role. Steam/oil plants, which currently account for almost one-quarter of Indonesia's installed capacity, witness a substantial decline; PLN retires $300 \mathrm{MW}$ of steam/oil capacity between 1991 and 2003 and does not add additional facilities.

Currently many of Indonesia's industries possess their own electricity-generating capacity. One of PLN's goals over the next decade is to take over some of this captive power and connect it to the PLN grid. As a result, the share of PLN power generation in total generation rises from $66 \%$ in 1990 to $92 \%$ in 2003 . In contrast, the moderate scenario foresees minimal captive power takeover. In this case, PLN's share in electricity generation is $76 \%$ in 2003.

PLN's current plans do not include nuclear power, but some leading Indonesian officials, particularly the Minister of Technology, have advocated its development. In 1991, the government invited bids for the construction of a nuclear power plant in Muria Peninsula in Central Java. ${ }^{23}$ The government hoped to begin construction in 1996 or 1997 and to complete the project by 2002-03. The Minister of Technology has said that Indonesia will have $7000 \mathrm{MW}$ of nuclear capacity by $2015 .^{24}$ Whether these plans will be implemented remains uncertain. In addition to potential opposition based on safety issues, there are some within the government who maintain that the country cannot afford the high capital costs of nuclear power.

\footnotetext{
23 "Bid for Nuclear Power Plant in Central Java," Inside Indonesia, February 1991.

24 "Nuclear Energy for Sure," Inside Indonesia, July 1992.
} 


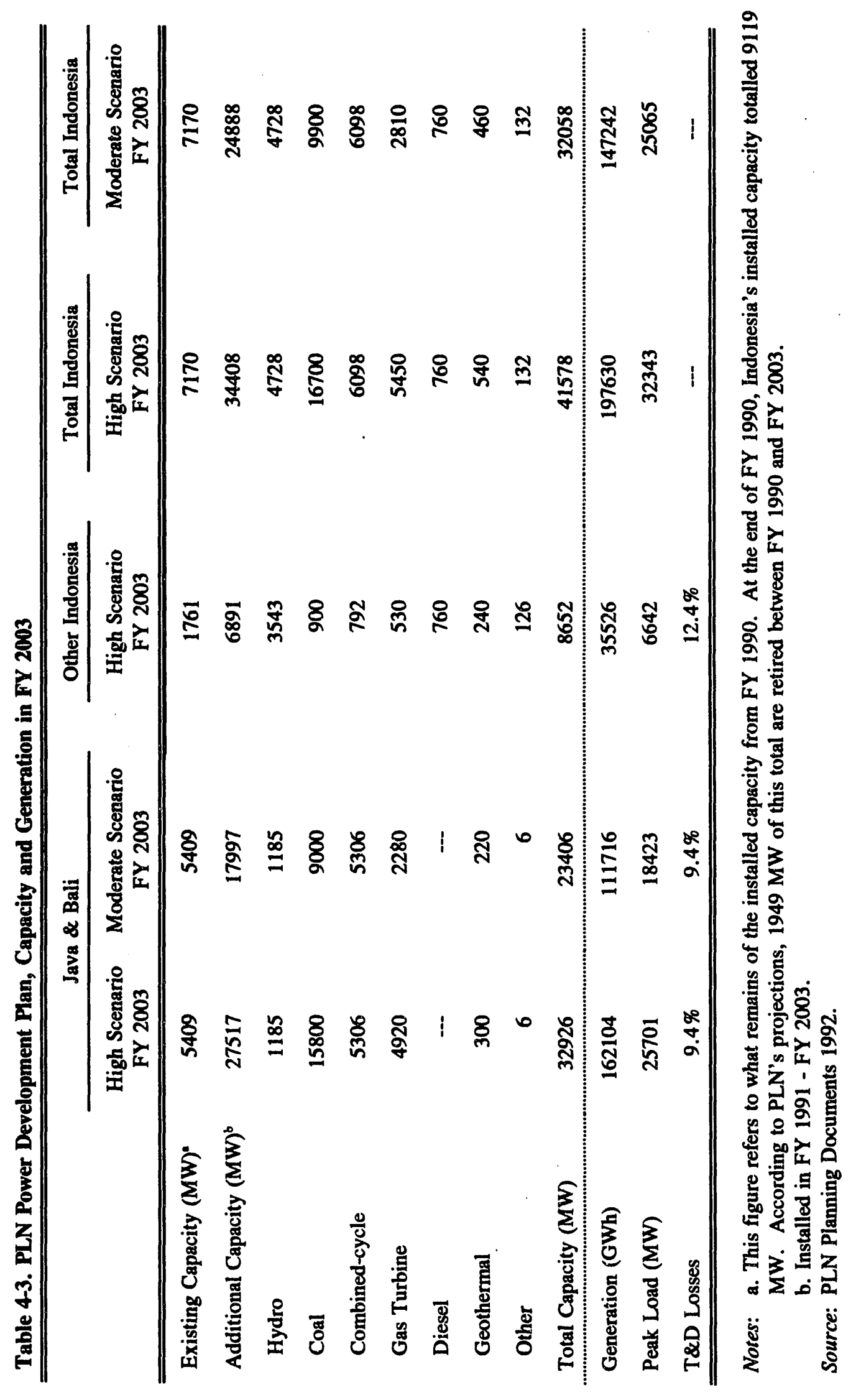


Table 4-4. PLN Installed Capacity (MW), FY 1991 and FY 2003

\begin{tabular}{|c|c|c|c|c|}
\hline \multirow[b]{2}{*}{$\begin{array}{l}\text { Plant } \\
\text { Type }\end{array}$} & \multirow{2}{*}{$\begin{array}{l}\text { FY } 1991 \\
\text { Installed } \\
\text { Capacity }\end{array}$} & \multicolumn{3}{|c|}{ FY 2003} \\
\hline & & $\begin{array}{c}\text { Remaining } \\
\text { Capacity } \\
\text { from FY 1991* }\end{array}$ & $\begin{array}{c}\text { Total } \\
\text { Capacity, } \\
\text { High Scenario }\end{array}$ & $\begin{array}{c}\text { Total } \\
\text { Capacity, } \\
\text { Moderate Scenario }\end{array}$ \\
\hline Hydro & $2116(23.3 \%)$ & $2110(29.4 \%)$ & $6838(16.4 \%)$ & $6838(21.3 \%)$ \\
\hline Coal & $1737(18.9 \%)$ & $1737(24.2 \%)$ & $18437(44.3 \%)$ & $11637(36.3 \%)$ \\
\hline Combined-cycle & $0 \quad(0.0 \%)$ & $0(0.0 \%)$ & $6098(14.7 \%)$ & 6098 (19.0\%) \\
\hline Steam/Oil & $2153(23.4 \%)$ & $1853(25.8 \%)$ & $1853(4.5 \%)$ & $1853(5.8 \%)$ \\
\hline Gas Turbine & $1094(11.9 \%)$ & $95(1.3 \%)$ & 5545 (13.3\%) & $2905(9.1 \%)$ \\
\hline Diesel & $1948(21.2 \%)$ & $1235(17.2 \%)$ & $1995(4.8 \%)$ & $1995(6.2 \%)$ \\
\hline Geothermal & $140(1.5 \%)$ & $140(2.0 \%)$ & $680(1.6 \%)$ & $600(1.9 \%)$ \\
\hline Other & $\ldots$ & $-\ldots$ & $132 \quad(0.3 \%)$ & $132 \quad(0.4 \%)$ \\
\hline TOTAL & $9188(100.2 \%)^{n}$ & $7170(99.9 \%)^{a}$ & $41578(99.9 \%)^{a}$ & $32058(100.0 \%)$ \\
\hline
\end{tabular}

Notes: a. Does not add up to $100 \%$ due to rounding.

Source: PLN Planning Documents 1992.

While small-scale renewable energy projects have not been incorporated into PLN's plan, the Indonesian government has begun to examine the possibility of expanding the use of renewables. Strong outside interest has surfaced about developing both biomass- and solargenerated electricity. ${ }^{25}$ The European Community has agreed to develop 180 mini-hydro projects on the Indonesian islands of Bali and West Sumatra. In addition, some untapped renewable resources, such as wind and ocean energy, may offer potential in certain regions. No concrete plans to develop either of these two renewable sources exist to date.

\section{Private Power Development}

As a means of attracting additional capital to expand the power base, the Indonesian government recently opened power development to private investors. Under the so-called build, own and operate system (BOO), private companies sign an agreement with PLN to finance the construction and operation of new power projects and to sell the resulting electricity generated to PLN.

In the moderate scenario, $6720 \mathrm{MW}$ of private projects come on line (mainly in $\mathrm{Java} / \mathrm{Bali}$ ) by 2003 . Hence, private projects constitute over one-quarter of the installed capacity added between 1991 and 2003. All of the private plants planned for construction in Java and

\footnotetext{
${ }^{25}$ Winrock International, a U.S. firm, has proposed a biomass project to the U.S. Agency for International Development (American Embassy, op cit., Ref. 7). In addition, a joint project funded by the Dutch and Indonesian governments and a Dutch company aims to install 2000 small solar-electricity generating projects in remote Indonesian villages; the first of these projects was put into place several years ago in Southern Jakarta ("2000 Solar Systems to be Installed," Inside Indonesia, February/March 1990).
} 


\section{Indonesia Power Development Plans Installed Capacity}

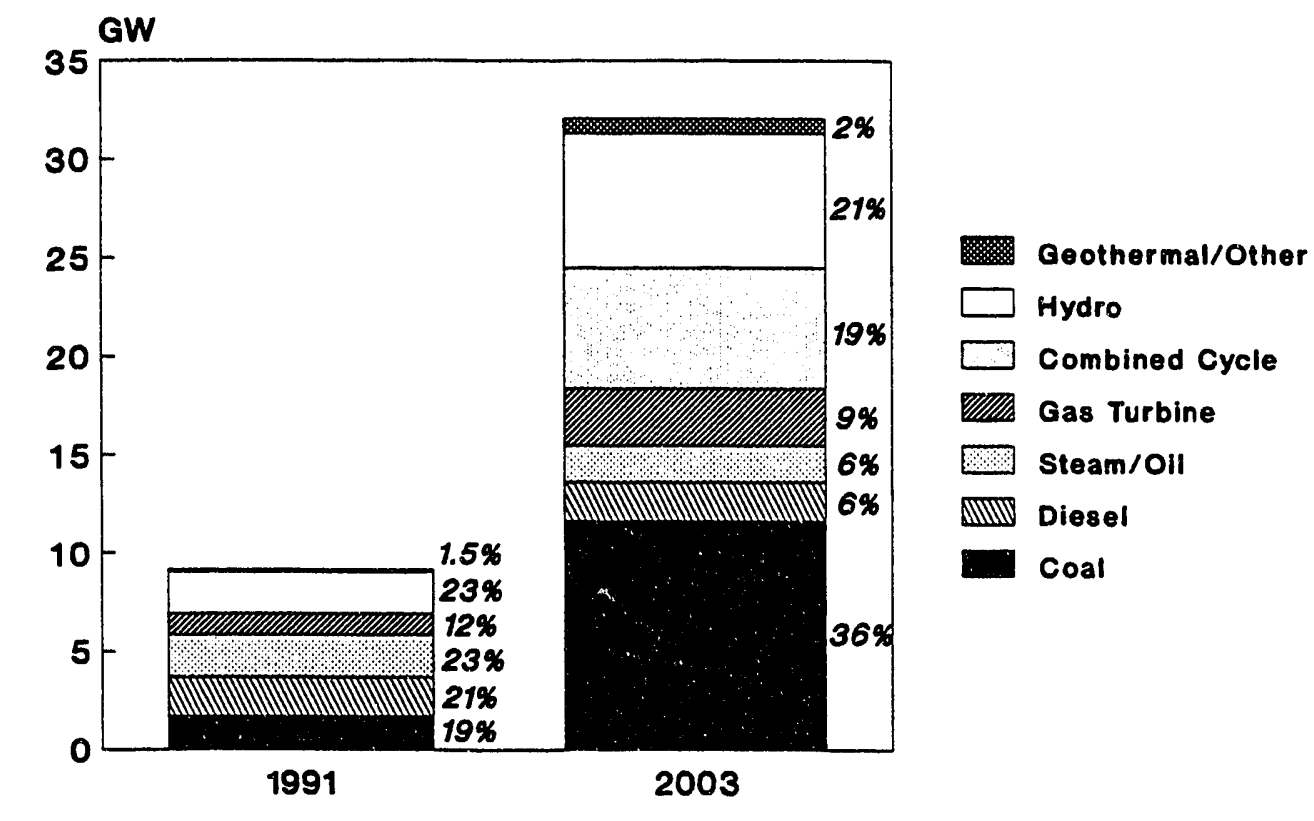

Note: 2003 is moderate scenario.

Figure 4-1 
Bali are to be coal-fired facilities. Outside of Java/Bali, the private facilities are comprised of two $120 \mathrm{MW}$ geothermal plants and one $110 \mathrm{MW}$ coal-fired plant. ${ }^{26}$ The composition and extent of private power participation in the high scenario is almost identical to that in the moderate scenario, aside from the inclusion of two additional $40 \mathrm{MW}$ geothermal facilities in Java and Bali.

While the basic framework for facilitating the growth of private power has been put into place, getting these projects off the ground may prove more challenging than originally anticipated. As of early 1992, the Indonesian government had begun negotiating contracts for the construction of the first two private facilities, to be comprised of four $600-\mathrm{MW}$ units in Paiton, East Java. The early stages of the negotiation process indicate that various barriers still exist to solidifying these deals. The potential investors want the government to guarantee that the price of electricity will be set at profitable levels over the long term. ${ }^{27}$ In turn, the government requires assurance that the investors have sufficient financial backing to cover the entire cost of projects they undertake. Other areas of uncertainty involve defining taxation schemes and legal frameworks that will be applied to the private power plants. Current estimated costs of the $5380 \mathrm{MW}$ of power facilities to be constructed by private investors between 1994 and 1998 stand at over US\$ 5 billion.

The utility also has considered promoting more widespread use of captive power among industries, and then purchasing this captive power from the individual industries during the peak period (6 p.m. - 10 p.m.). Preliminary calculations indicate that purchasing electricity might cost the utility more than generating power from PLN sources, but this issue requires a more thorough examination. ${ }^{28}$

\subsection{Financial Issues}

The expansion of Indonesia's power sector will require large capital outlays. Along with the costs of adding new capacity, the need to provide electricity to burgeoning industrial centers in remote areas will require considerable development of transmission and distribution systems. $^{29}$

\footnotetext{
${ }^{26}$ While the high costs of developing geothermal energy historically have hindered its exploitation, the Indonesian government currently is in the process of investigating opportunities for private sector involvement. Private sector interest appears strong. The government also has begun taking measures to remove some of the cost barriers associated with geothermal power development. In November 1991, for example, the government cut the tax burden on profits from geothermal steam sales by $16 \%$. Previously, the tax rate stood at $48 \%$ (American Embassy, op cit., Ref. 7).

27 A central challenge associated with setting prices over the long term is that electricity bills are paid in rupiah, whereas private investors have to pay back their loans in dollars. It is difficult to develop a pricing structure for the future because of uncertainties caused by foreign exchange fluctuations (Borsuk, Richard, "Jakarta's Two-Track Privatization Effort for Power Supply Faces High Hurdles," The Asian Wall Street Joumal Weekly, February 3, 1992).

28 American Embassy, op cit., Ref. 7.

29 American Embassy, op cit., Ref. 7.
} 
An earlier version of PLN's latest power plan, with future levels of demand only slightly below the more recent high scenario projections, estimated total capital costs at US\$ 9 billion (1989 dollars) for the years 1990-93. For the following 14-year period, PLN estimated that US\$ 67 billion (1991 dollars) in capital investments would be required. ${ }^{30}$ According to the utility's plans, approximately two-thirds of that total would come from foreign sources.

PLN receives significant support from the World Bank. Current World Bank investments total US\$ 1.2 billion for a transmission and distribution project, a power sector efficiency project, a thermal power project and a rural electrification project. The Asian Development Bank (ADB) currently is financing a 55-MW geothermal plant in Java and two hydroelectric plants (1x11 MW in South Sumatra and 2x30MW in Summatra). The World Bank has agreed to finance three $600-\mathrm{MW}$ coal-fired units at Suralaya to be built by 1996 , with ADB assistance. Both agencies have expressed interest in financing various other projects. The Indonesian power sector has also received support from bilateral donor nations. ${ }^{31}$

The price of electricity has remained an area of great contention in Indonesia. Between 1984 and 1988 electricity prices in the residential sector remained flat and industrial electricity prices witnessed a $9 \%$ drop. The average electricity tariff across all sectors fell by about $6 \%$ during this period. ${ }^{32}$ Per capita incomes are extremely low in Indonesia, and efforts to raise the consumer power costs have met with strong opposition. In 1989, PLN raised the price of electricity by almost $25 \%$. While consumers were angered by this tariff increase, the utility argued that even with the new prices it was unable to pay for needed capacity expansions. Since 1989, PLN has raised the tariff two more times, once in 1991 and 1993.

\subsection{Environmental Considerations}

In 1986 the government passed a regulation mandating that environmental impact analyses (EIA) be carried out during the planning process for new projects as well as for existing projects that have been associated with environmental decline. A 1988 progress appraisal determined that the new policy had not been satisfactorily carried out, and modifications aimed at tightening the directive were put in place..$^{33}$

In 1990 Indonesia consumed 4.6 million tons of coal for electricity generation (up from 0.2 million tons in 1984). Even the more modest increase in coal capacity captured in PLN's moderate scenario for 2003 would require coal consumption many times greater than current levels. Thus, both scenarios raise serious concerns in terms of local environmental issues and

\footnotetext{
${ }^{30}$ Broken down further, USS 37 billion would go towards investment in generation, US\$ 10.6 billion towards transmission and US\$ 19.0 billion towards distribution.

${ }^{31}$ American Embassy, op cit., Ref. 7.

3 PLN, PLN Statistics 1990/91, 1991.

${ }^{33}$ Asian Development Bank, Environmental Considerations in Energy Development, May 1991.
} 
carbon dioxide emissions. One study foresees $\mathrm{CO}_{2}$ emissions from energy use in Indonesia rising from 99 million tons to 469 million tons between 1986 and 2010 if current trends prevail. ${ }^{34}$ According to this study, higher levels of household and industrial electricity consumption and increased reliance on less efficient and less clean fuels in electricity production largely contribute to this rise.

The further development of hydro resources also plays a key role in PLN's plans -particularly in regions outside of Java and Bali. As has been the case in many other developing countries in Asia, controversy has surrounded plans to develop hydro projects in Indonesia. Two major hydro projects recently were canceled and, as of May 1991, the courts were in the process of deciding the fate of two other planned facilities (the Kedungombo project in Central Java and Saguling Dam in West Java). In all four cases, concern has stemmed primarily from the resettlement requirements and land acquisition problems associated with the projects. ${ }^{35}$

Java is likely to experience some of the most severe local environmental impacts of further power development in Indonesia, because the vast majority of future electricity growth will take place on this small island. The unavailability of land is likely to serve as a major obstacle to further hydro development in Java in coming years. The growth of coal-generated power also will face major constraints, as the heavy use of coal takes a toll on Java's local environment. A long-term projection by the Asian Development Bank indicates that lack of suitable sites in Java will severely constrain PLN's ability to increase its installed coal capacity on the island after the year 2005. ${ }^{36}$ PLN's options for the longer term might then include developing nuclear power on Java, expanding the use of natural gas and/or generating coal-fired electricity on neighboring islands and transmitting it to Java.

\subsection{Electricity Supply and End-Use Efficiency}

The majority of PLN's installed thermal capacity is relatively new. The average efficiency of Indonesia's fossil fuel plants stood at about $33 \%$ in 1990, but this estimate includes many low-efficiency diesel units. The planned increase in the use of combined-cycle plants will boost the average efficiency.

Transmission and distribution (T\&D) losses have dropped from previously high levels to about $15 \%$. Line theft remains a problem; on average, about $4 \%$ of electricity production is lost due to theft. ${ }^{37}$ According to the scenarios, the transmission and distribution of electricity continues to witness considerable improvements in efficien zy. Within Java and Bali, T\&D losses

\footnotetext{
34 The study states that if Indonesia were to switch to a cleaner energy mix, emissions could be contained to 351 million tons in 2010 (Sari, Agus, " $\mathrm{CO}_{2}$ Emissions: The Energy Sector," Environesia: Climate Change \& Energy, Vol.6, Nos.4-5, November 1992).

3s Asian Development Bank, op cit., Ref. 33.

${ }^{36}$ Ibid.

"American Embassy, op cir., Ref. 7.
} 
drop from $15.2 \%$ in 1990 to $9.4 \%$ in 2003 . In other parts of Indonesia, losses fall from an average of $17.7 \%$ to $12.4 \%$.

As a load-management strategy, PLN has established time-of-day pricing in the commercial and industrial sectors; electricity tariffs are higher at peak times than at off-peak times. In the residential sector, electricity tariffs increase at higher levels of consumption.

Indonesia currently has no efficiency standards for appliances or industrial equipment, and few incentives exist to improve efficiency. In the industrial sector, companies are not taxed for imports of less efficient, second-hand machinery. However, PLN recently has shown greater interest in incorporating demand-side management (DSM) into future electricity sector planning. Projects under consideration include the installation of compact fluorescent light bulbs in lowincome housing and electronic ballasts in government buildings.

\subsection{Conclusion}

Indonesia has both a broad array of energy resources and ambitious plans to expand its generating capacity. PLN's plans call for growth in installed capacity from 9.2 GW in FY 1991 to between 32 and $42 \mathrm{GW}$ in FY 2003. This corresponds to an average annual growth rate of $11-13 \%$. Coal is to see the largest increase, but the plans also call for $6.1 \mathrm{GW}$ of combined-cycle power plants fired with natural gas and an additional $4.7 \mathrm{GW}$ of hydropower.

To meet its goals for the power sector, the government is relying heavily on private sector participation. In the moderate scenario, private projects (nearly all coal-fired) constitute over one-quarter of the additional installed capacity. Whether private investors respond as enthusiastically as the government would like remains to be seen. As of yet, neither PLN nor the government have taken serious interest in policies to improve end-use efficiency, but that could change if demand grows rapidly and the power situation worsens. 


\section{SOUTH KOREA}

\subsection{Introduction}

Over the past two decades, South Korea has enjoyed sustained economic growth driven by a process of robust industrialization. While energy use (and GNP) averaged growth rates of nearly $9 \%$ /year between 1970 and 1991 , the growth in electricity demand was much more vigorous -- $13 \%$. On a per capita basis, public electricity consumption multiplied almost tenfold between 1970 and 1991.

Korea Electric Power Company (KEPCO), a largely state-owned utility, serves as the major generator and sole distributor of the nation's public electricity supply. Two other enterprises -- Kyungin Energy Company, a private company, and the Industrial Site and Water Development Corporation (ISWACO), a hydropower company supported by government funds - generate electricity which they then sell to KEPCO for distribution. ${ }^{1}$

The composition of South Korea's power sector has undergone a distinct transition over the past decade and a half. Galvanized by the oil price shocks and the dearth of indigenous energy supplies, the South Korean government made a concerted effort to minimize the nation's oil dependence starting in the 1970s. South Korea's power sector hardily embraced nuclear power. Its first commercial nuclear plant, with an installed capacity of $587 \mathrm{MW}$, commenced operation in 1978. Since then, the use of nuclear power has skyrocketed. Installed nuclear capacity rose from $587 \mathrm{MW}$ to $7616 \mathrm{MW}$ in 1991 -- a far more substantial increase than the mere doubling of installed capacity from non-nuclear sources over the same period. In 1977, prior to the installation of the first nuclear plant, oil plants accounted for $89 \%$ of South Korea's electricity generation; by 1991 , oil's share in electricity generation had fallen to under $23 \%{ }^{2}$

As of 1991, South Korea had an installed generating capacity of $21.1 \mathrm{GW}$, more than twice the $9.4 \mathrm{GW}$ of installed capacity in 1980 (Table 5-1). The nation's nine nuclear plants, with a combined capacity of $7.6 \mathrm{MW}$ in 1991 , accounted for over one-third of the total installed capacity, followed by oil-fired thermal plants with $4.8 \mathrm{GW}$, coal-fired thermal plants with 3.7 $\mathrm{GW}$, gas-fired thermal with $2.6 \mathrm{GW}$ and hydro facilities with $2.4 \mathrm{GW}$.

Nuclear sources accounted for almost half of the public electricity generated in 1991. Coal accounted for anviher $17 \%$ of this total. Both coal and nuclear comprise greater shares of total electricity generation than of installed generating capacity, since these sources are used to satisfy base and intermediate load generation. In contrast; the more costly options of oil and

\footnotetext{
'As of 1991 , KEPCO owned approximately $85 \%$ of the total installed capacity in South Korea, and Kyungin Energy Company and ISWACO owned the remaining 15\% (Intermational Energy Agency (IEA), Energy Policies of the Republic of Korea, OECD, 1992). Throughout this paper, the installed capacity and generation provided by these two generating authorities are included in the KEPCO figures.

${ }^{2}$ In 1990 , oil's share in electricity generation hit a low of 18 percent. Electricity shortages led to a greater reliance on oil generation the following year.
} 
natural gas are relegated to peak load generation, resulting in the lower contribution of these electricity sources to electricity generation relative to installed capacity.

Table 5-1. Public Installed Capacity, Electricity Generation and Consumption in South Korea"

\begin{tabular}{|c|c|c|}
\hline & 1991 & $\begin{array}{l}\text { AAGR } \\
1980-90\end{array}$ \\
\hline Installed Capacity (MW) & $21110(100.0 \%)$ & $8.4 \%$ \\
\hline Hydro & $2445(11.6 \%)$ & $7.3 \%$ \\
\hline Thermal & $11050(52.3 \%)$ & $3.8 \%$ \\
\hline Coal-fired & $3700(17.5 \%)$ & $15.3 \%$ \\
\hline Oil-fired & $4800(22.7 \%)$ & $-3.3 \%$ \\
\hline Gas-fired & $2550(12.1 \%)$ & b \\
\hline Nuclear & $7616(36.1 \%)$ & $25.6 \%$ \\
\hline Generation (GWh) & $118619(100.0 \%)$ & $11.2 \%$ \\
\hline Hydro & $5051 \quad(4.3 \%)$ & $12.4 \%$ \\
\hline Thermal & $57257(48.3 \%)$ & $4.3 \%$ \\
\hline Coal-fired & $20025(16.9 \%)$ & $23.2 \%$ \\
\hline Oil-fired & $27335(23.0 \%)$ & $-4.3 \%$ \\
\hline Gas-fired & $9897(8.3 \%)$ & b \\
\hline Nuclear & $56331(47.5 \%)$ & $31.3 \%$ \\
\hline Consumption (GWh) & $104374(100.0 \%)$ & $11.2 \%$ \\
\hline Industrial & $65183(62.4 \%)$ & $10.0 \%$ \\
\hline Residential & $19482(18.8 \%)$ & $12.8 \%$ \\
\hline Commercial & $18618(17.8 \%)$ & $14.8 \%$ \\
\hline Transportation & $1019(1.0 \%)$ & $9.8 \%$ \\
\hline
\end{tabular}

Notes: a. Electricity generation by self-producers was estimated at $7000 \mathrm{GWh}$ in 1990.

b. LNG was not introduced into the electricity mix until the mid-1980s.

Source: Korea Energy Economic Institute, Yearbook of Energy Statistics 1992, Ministry of Energy and Resources, 1992.

During the early- and mid-1980s, South Korea's power sector had a comfortable reserve margin. In recent years, however, this situation has eroded, due largely to a boom in residential and commercial demand which was not supported by a commensurate increase in generating capacity. South Korea's reserve margin plummeted to a low of $10.3 \%$ in $1991 .^{3}$ (International standards typically consider a sufficient reserve margin in the realm of $15 \%$.) At various points

${ }^{3}$ Ministry of Energy and Resources, Long-Term Electricity Supply and Demand Plan (1991-2006), October 1991. 
in the year, the margin was even lower. ${ }^{4}$ Under these conditions, the temporary closure of a single large power plant could result in local black outs or brown outs.

A series of technical problems at some of the nuclear facilities also have contributed to recent shortages. At $79.3 \%$ in 1990 , the average capacity factor of South Korea's nuclear power plants far surpassed the world average of $65.7 \% .^{5}$ However, the plants have suffered from difficulties, including both generator and turbine problems, which in certain instances have prompted the short-term closure of power plants. ${ }^{6}$ Although the government's plans to expand generating capacity foresee a far wider reserve margin in years to come, the near-term situation remains somewhat precarious, particularly during the hot summer months when the demand for air conditioning soars.

\subsection{Resources for Electricity Generation}

The recent evolution of South Korea's power sector -- and the plans for its future development -- reflect the nation's sparse natural resource base. South Korea's indigenous energy reserves are limited to 600 million tonnes of anthracite coal and minimal untapped hydro potential. At current rates of consumption, the nation's anthracite would last for approximately 20 more years. Most of the as-of-yet unmined coal reserves have a low calorific value and lie in deep mines, making them costly to retrieve. ${ }^{7}$ A recent geological survey also indicated that Korea possesses reserves of uranium; due to the currently low price of uranium on the international market, however, Korea has chosen to postpone the development of this indigenous resource. $^{8}$

For this reason, South Korea has watched imports rapidly displace indigenous energy resources. In the past decade alone, imported energy as a share of total energy use rose from $74 \%$ to $88 \%$. South Korea currently imports oil, LNG, coal and uranium for electricity generation. Various South Korean companies have launched exploratory ventures, typically with generous financial backing from the government, in the hopes of finding off-shore oil. The South Korean government also has encouraged overseas resource development and exploration projects. As of 1991, Korean companies were participating in over 30 projects aimed at the development of oil, coal and uranium in 19 different countries. ${ }^{9}$

\footnotetext{
4 In June 1991, KEPCO reported electricity reserves of approximately 4\%. Two months earlier, technical problems forced the Kori power plant to temporarily shutdown; as a result, the nation's reserve margin fell to an uneasy $2.2 \%$. (Darlin, Damon, "South Korea Faces Shortage of Electricity," The Wall Street Joumal, June 18, 1991, p.A14).

s Park, Chung-Taek, "The Experience of Nuclear Power Development in the Republic of Korea," Energy Policy, August 1992, pp.721-734.

'Goldstein, Carl, "Tarnished Image," Far Eastem Economic Review, July 4, 1991, pp. 41-43.

' Park, Chung-Taek, op cil., Ref. 5.

' "Korea's Long-Term Power Development Plan," Asian Energy News, Vol. 2, No. 10, October 1992, p.13.

${ }^{9}$ Ministry of Energy and Resources, Energy Situation and Policy in Korea, 1991.
} 


\subsection{Forecast of Electricity Demand ${ }^{10}$}

The projections of electricity consumption issued by the Ministry of Energy and Resources in 1991 assume the nation's GNP rises at an average annual rate of $7.5 \%$ in 1992$1996,6.0 \%$ in $1997-2001$ and $5.0 \%$ in $2002-2006$. Relative to the 1987-1990 average GNP growth rate of $10.2 \%$ per year, this forecast assumes a notable decline.

The Ministry's projections show electricity consumption rising from 104 TWh in 1991 to $216 \mathrm{TWh}$ in 2001 and $270 \mathrm{TWh}$ in 2006 (Table 5-2). Between 1991 and 1996, demand increases more rapidly than GNP at an average annual rate of $9.1 \%$. Consumption grows at the same rate as GNP between 1997 and $2001-6 \%$ per year. In the final period, electricity consumption grows more slowly than GNP at a rate of $4.5 \%$ per annum. The industrial sector continues to dominate electricity consumption in the future, although its share drops considerably over the 15-year period. Electricity consumption in the commercial and residential sectors grow at roughly the same rate $(23 \% /$ year). These sectoral projections represent a tapering off of heavy industrialization and a movement towards a more services-oriented economy.

Peak demand rises slightly more slowly than electricity consumption, increasing from $19.1 \mathrm{GW}$ in 1991 to $38.4 \mathrm{GW}$ in 2001 and $48.2 \mathrm{GW}$ in 2006.

Table 5-2. Projection of South Korean Electricity Consumption and Peak Demand, 1991-2006

\begin{tabular}{|c|c|c|c|c|}
\hline & 1991 & 1996 & 2001 & 2006 \\
\hline Consumption (GWh) & 104374 & 161578 & 215917 & 26949 \\
\hline Industrial & $63 \%$ & $59 \%$ & $57 \%$ & $54 \%$ \\
\hline Residential & $19 \%$ & $21 \%$ & $22 \%$ & $23 \%$ \\
\hline Commercial & $19 \%$ & $20 \%$ & $21 \%$ & $23 \%$ \\
\hline Peak Demand (MW) & 19124 & 28752 & 38409 & 48155 \\
\hline
\end{tabular}

Note: Includes transportation sector.

\subsection{Plans for Power Sector Development ${ }^{11}$}

The "Long-Term Electricity Supply and Demand Plan," issued by the Ministry of Energy and Resources in October 1991, lays out the blueprint for the evolution of South Korea's power sector through the year 2006. The power development strategy continues to focus on diminishing the role of oil in the electricity sector. In a clear continuation of past trends,

\footnotetext{
${ }^{10}$ The electricity demand forecast data were drawn from: Ministry of Energy and Resources, op cit, Ref. 3. The average annual growth rates provided in the following two sections may differ slightly from those contained in the Ministry report due to slightly different methods for calculating this indicator. However, because the Ministry report does not provide absolute values for future GNP, the GNP growth rates presented here are taken directly from the report.
}

"All the data on Korea's power development plans were drawn from: Ministry of Energy and Resources, op cit, Ref. 3. 
nuclear power and bituminous coal come to supplant much of the electricity formerly supplied by oil. LNG plants also take on a greater role in the power mix.

The plan foresees the power base expanding by $44.8 \mathrm{GW}$ of installed capacity between 1991 and 2006 (Table 5-3). Nuclear facilities account for $16.2 \mathrm{GW}$ of this total and coal plants for $15.2 \mathrm{GW}$. The strikingly low number of new oil-fired facilities -- only two oil-fired plants are planned for construction between 1991 and 2006 with a combined capacity of just 20 MW - reflects the Ministry's commitment to weaning the nation off of oil-generated electricity.

Table 5-3. South Korea's Long-Term Power Development Plan, 1991-2006 - Installed Capacity

\begin{tabular}{|c|c|c|c|c|c|}
\hline \multirow[t]{2}{*}{ Plant Type } & \multirow{2}{*}{$\begin{array}{c}\begin{array}{c}\text { Existing } \\
\text { MW (\%) }\end{array} \\
1990\end{array}$} & \multicolumn{2}{|c|}{$\begin{array}{l}\text { Additional Installed Capacity } \\
\text { MW (Number of Plants) }\end{array}$} & \multicolumn{2}{|c|}{$\begin{array}{c}\text { Total } \\
\text { MW (\%) }\end{array}$} \\
\hline & & $1991-2001$ & $2002-2006$ & 2001 & 2006 \\
\hline Hydro & 2339 (11.1\%) & $2130(16)$ & $1500(6)$ & $4469 \quad(9.5 \%)$ & $5969(10.2 \%)$ \\
\hline Coal & $3700(17.6 \%)$ & $12440(25)$ & 2800 (4) & $15160(32.3 \%)$ & $17760(30.2 \%)$ \\
\hline Oil & 4816 (22.9\%) & $20(2)$ & - & $4831(10.3 \%)$ & $1731 \quad(3.0 \%)$ \\
\hline Gas & $2550(12.1 \%)$ & $5230(8)$ & $4500(6)$ & $6767(14.4 \%)$ & $9980(17.0 \%)$ \\
\hline Nuclear & $7616(36.2 \%)$ & $8100(9)$ & $8100(9)$ & $15716(33.5 \%)$ & $23229(39.6 \%)$ \\
\hline Total & $21021(100.0 \%)$ & $27920(60)$ & $16900(25)$ & $46943(100.0 \%)$ & $58669(100.0 \%)$ \\
\hline
\end{tabular}

These new facilities will add an additional $44.8 \mathrm{GW}$ of installed generating capacity to South Korea's current base. Taking into account the retirement of various existing plants, South Korea's installed capacity reaches $46.9 \mathrm{GW}$ in 2001 and $58.7 \mathrm{GW}$ in 2006 . Together, nuclear and coal account for about $70 \%$ of the additional capacity to be built through 2006 (Figure 5-1).

According to the plan, total electricity generation rises almost threefold, from $108 \mathrm{TWh}$ in 1990 to 241 TWh in 2001 and 301 TWh in 2006 (Table 5-4). In absolute terms, electricity generation from nuclear sources witnesses the most substantial increase. Nuclear's share in generation expands to $52 \%$ by 2006 . Most of the remaining electricity generation is provided by coal and gas with $32 \%$ and $11 \%$ respectively. The growth rates of coal, gas and nuclear generated electricity over the 1990-2006 period remain strong $(10.4 \%$ /year, $8.2 \%$ /year and $7.0 \%$ /year respectively), but by no means approach the growth rates witnessed in the prior decade. In stark contrast, electricity generation from oil and hydro sources fall at average annual rates of 4.6\%/year and 2.8\%/year respectively between 1990 and 2006 . Nuclear and bituminous coal continue to satisfy the bulk of the base load generation.

As the nation's generating capacity expands over the next 15 years, the reserve margin steadily rises to $19.7 \%$ by 1996 and vacillates between 21 ariu $23 \%$ after 1999 . 


\section{S. Korea Power Development Plans Installed Capacity}

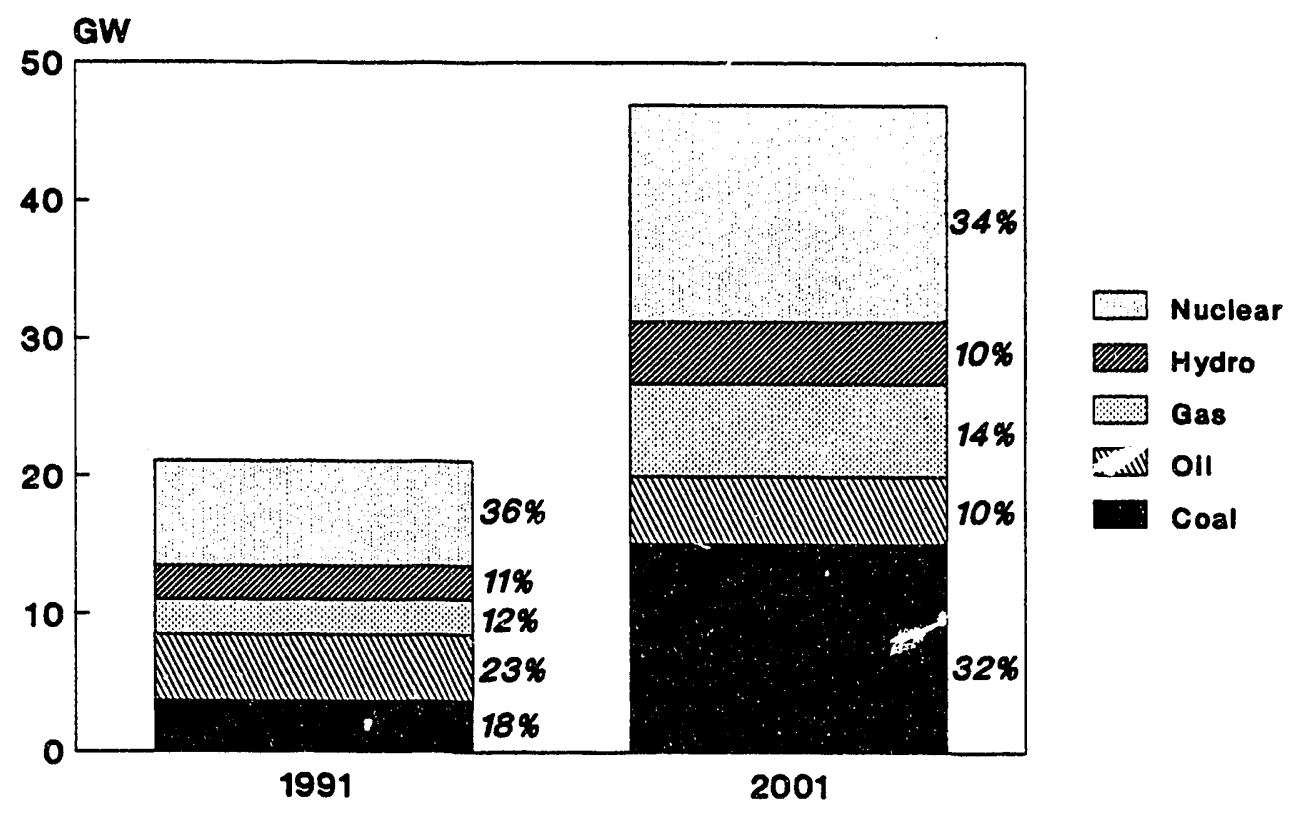

Figure 5-1 
The use of bituminous coal and LNG witness a substantial rise over the 15-year period, whereas oil use declines (Table 5-5). Anthracite coal is largely phased out of the primary fuel mix in favor of bituminous coal, due to cost considerations.

Table 5-4. Projection of South Korean Electricity Generation, 1991-2006

\begin{tabular}{lrrrrr}
\hline & 1990 & 1996 & 2001 & 2006 & $\begin{array}{c}\text { AAGR } \\
1990-2006\end{array}$ \\
\hline Generation (GWh) & 107671 & 180870 & 241205 & 301070 & $6.6 \%$ \\
Hydro & 6361 & 3666 & 3923 & 4048 & $-2.8 \%$ \\
Nuclear & 52887 & 65171 & 104379 & 156868 & $7.0 \%$ \\
Coal & 19961 & 55965 & 84600 & 97247 & $10.4 \%$ \\
Oil & 18858 & 30281 & 22311 & 8946 & -4.6 \\
Natural Gas & 9604 & 25787 & 25996 & 33961 & $8.2 \%$ \\
\hline \hline
\end{tabular}

Source: Ministry of Energy and Resources, Long-Term Electricity and Demand Plan (1991-2006), October 1991.

Table 5-5. Fuel Consumption for Electricity Generation in South Korea

\begin{tabular}{lcc}
\hline Primary Fuel & 1991 & 2006 \\
\hline \hline Coal $\left(10^{3}\right.$ tons) & 9061 & 34582 \\
Bituminous & 7017 & 33732 \\
Anthracite & 2044 & 850 \\
LNG $\left(10^{3}\right.$ tons) & 1811 & 5972 \\
Oil $\left(10^{3} \mathrm{KL}\right)$ & 7642 & 2162 \\
Heavy & 7254 & 2038 \\
Light & 388 & 124 \\
Uranium (tons) & 250 & 1174 \\
\hline \hline
\end{tabular}

Source: Ministry of Energy and Resources, Long-Term Electricity and Demand Plan (1991-2006), October 1991.

The government continues to strive for technological self-sufficiency in the power sector. The rising degree of indigenous contractors, components and other materials in the construction of nuclear power plants over the past decade reflects this priority. ${ }^{12}$ The latest plan calls for local participation to comprise at least a $95 \%$ share in new nuclear power plants with capacities of $1000 \mathrm{MW}$ and less and new coal plants with capacities of $500 \mathrm{MW}$ and less. One of the

\footnotetext{
${ }^{12}$ Park, Chung-Taek, op cit., Ref. 5. As of 1991, KEPCO's hydro and thermal plants had a local content of above $65 \%$. The two nuclear units built in 1989 had a local content of $40 \%$ (IEA, op cit., Ref. 1).
} 
goals for the future of nuclear power development is to develop a standard nuclear power plant model, which would improve the safety of these facilities and cut their costs. ${ }^{13}$

On top of this growth, electricity generation by self-producers is projected to grow considerably, from about $10 \mathrm{TWh}$ in 1991 to over $18 \mathrm{TWh}$ by $2000 .^{14}$

\subsection{Financial Issues}

Throughout the boom in electricity demand, KEPCO has managed to avoid many of the economic pitfalls that afflict government-owned utilities in other developing countries, in part by accruing revenues high enough to cover both operating costs and debt service. In recent years, however, public criticisms decrying KEPCO's high profits have led the government to lower electricity prices. Between 1985 and 1990, KEPCO cut the price of electricity by almost $26 \% .^{15}$ This drop in prices may have contributed to the particularly high growth rates of electricity consumption during the latter half of the 1980s. Another cost increase is expected in the near future. ${ }^{16}$

The construction of new power plants is expected to require an investment of US\$70 billion through 2001. KEPCO's estimates imply an average annual investment of US\$4.5 billion for generation facilities and US\$ 2.5 billion for transmission, distribution and other equipment between 1991 and 2001. Despite KEPCO's historic profitability, the utility is likely to only generate about US\$ 3 billion per year in internal funds, which suggests that KEPCO will need to borrow approximately \$US 3-4 billion per year. For this reason, KEPCO is expected to directly borrow capital from overseas for the first time in the utility's history. ${ }^{17}$

The government also plans to implement various cost-conserving measures outlined in the power plan. These measures range from extending the life of plants to shortening the construction periods of new facilities to improving load management to rationalizing the management of the power sector. The government is also considering promoting the construction of power plants by independent power producers, who would then sell power to KEPCO. ${ }^{18}$

\footnotetext{
${ }^{13}$ Ministry of Energy and Resources, op cit., Ref. 9.

14 IEA, op cit., Ref. 1.

is Clifford, Mark, "A Shot in the Dark," The Far Eastem Economic Review, August 1, 1991, pp.54-55. During this same period, prices on other consumer goods rose by approximately 30 percent.

${ }^{16}$ IEA, op cit., Ref. 1.

${ }^{87}$ Ibid.

18 Ibid.
} 
In an attempt to contain costs, KEPCO is seeking to change the current arrangement under which it is obligated to buy $90 \%$ of its generating equipment from the Korean supplier, at $20-40 \%$ above the international prices. ${ }^{19}$

Expected increases in the costs of nuclear power could pose a barrier to its future development. The cost of the two Yeongkwang units currently under construction (US\$ $2160 / \mathrm{kW}$ ) is almost double that of plants built in the 1980 s. $^{20}$ If construction costs continue to rise, due in part to tightening safety requirements and longer lead times, the cost advantages of nuclear plants relative to fossil fuel sources may diminish. Other factors could also make nuclear less economically attractive -- including the increasing financial burdens associated with radioactive waste disposal and a limited export market for Korean nuclear reactors and fuels. ${ }^{21}$ However, the government plans to improve the economics of nuclear power over the short term by minimizing the number of plant shutdowns, constricting the timed outages dedicated to plant refueling and improving the thermal efficiency of the nuclear plants. Over the longer term, KEPCO hopes to improve the operational management of its plants and upgrade various systems. $^{22}$

\subsection{Environmental Considerations}

The Ministry of Environment (MOE) possesses most of the authority over energy-related environmental decisions. MOE's funding and status have risen in recent years, as issues such as nuclear plant safety and waste disposal increasingly have attracted public attention. The government has mandated Environmental Impact Assessments (EIA) before the construction of all power plants and hydroelectric dams since 1981. The recently enacted Basic Law for National Environmental Policy tightens this mandate; under the new law, the impact assessment process must include a public hearing and an appraisal of public response to new projects. ${ }^{23}$

The government has faced an ever-increasing level of public opposition to nuclear power in recent years. South Korean society seems torn between the potential opportunity for securing a sufficient electricity supply and the strong distrust of nuclear sources. A 1987 study on public attitudes towards nuclear power found that $70 \%$ of those surveyed supported the nation's nuclear power program, but $80 \%$ of those in favor of nuclear development stated that they were opposed to the construction of nuclear facilities near their homes. ${ }^{24}$ Vociferous opposition from local

\footnotetext{
19 "KEPCO to Allow Foreign Investors to Buy Stakes," Asian Energy News, November 1992.

${ }^{20}$ Park, op cit., Ref. 5.

21 Ibid.

2 IEA, op cit., Ref. 1.

${ }^{23}$ Rhee, Deok-Gil, "Environmental Challenges in the 1990s: A Korean Context," In: K.V. Ramani, P. Hills and G. George (eds), Buming Questions, Asian and Pacific Development Centre, Kuala Lumpur, 1992, pp.287-295.

24 Park, op cit., Ref. 5.
} 
groups served as a barrier to the Ministry's expansion plans. In 1989, local demonstrations erupted in the vicinity of the $1900 \mathrm{MW}$ Yeonkwang nuclear power plant, galvanized by evidence of radiation-related birth defects in the children of some plant workers and of other related health problems in local residents. ${ }^{25}$ The government denied the allegations and moved forward with plans to build two more $1000 \mathrm{MW}$ nuclear reactors at the site. The following year, plans to build a nuclear waste storage and research center led to protests on Anmyon Island. Environmental groups have become more involved in the nuclear issue, providing a cohesion and strength to sporadic local movements.

The government's power program articulates plans to adopt a series of measures aimed at addressing some of the safety, health and environmental concerns associated with nuclear power. In the meantime, KEPCO's strategy has been to wage public education campaigns.

The main competitor to nuclear power, coal, faces problems of its own: air quality threats from sulfur dioxide $\left(\mathrm{SO}_{2}\right)$ and particulates as well as emissions of greenhouse gases. The almost five-fold increase in coal-fired generation expected by the year 2006 does not bode well for air quality. KEPCO has been slow to incorporate stringent emissions controls on its coal power plants, due largely to a lack of R\&D and capital. ${ }^{26}$ Most of Korea's coal-burning facilities do not have SOx or NOx controls and the government does not require power plants to install flue gas desulphurization.

KEPCO has called for a greater emphasis on anti-pollution technologies. The utility plans to invest a total of US\$ 3.6 billion in flue gas desulphurization (US\$ 3.02 billion), electrostatic precipitators (US\$ 0.24 billion), De-NOx equipment (US\$ 0.10 billion) and water treatment plants (US $\$ 0.24$ billion) between 1992 and $2001 .^{27}$

\subsection{Electricity Supply and End-Use Efficiency}

Faced with limited supplies of indigenous energy, South Korean energy planners made various attempts to improve the efficiency of electricity generation and transmission early in the nation's industrialization process. During the 1960s, the government merged the nation's three utilities into one more efficient body (Korea Electric Company Limited, later to become KEPCO) and later implemented a major program which successfully reduced transmission and distribution (T\&D) losses. ${ }^{28}$ In response to the oil crises of the 1970 s and 1980 s, additional supply-side efficiency measures were implemented: more efficient power plants were built,

\footnotetext{
${ }^{2 s}$ Clifford, Mark, "Nuclear Falling Out," Far Eastem Economic Review, August 31, 1989, p.46.

${ }^{26}$ Rhee, op cit., Ref. 23.

${ }^{27}$ IEA, op cit., Ref. 1.

${ }^{28}$ Between 1961 and 1966, transmission and distribution losses dropped from 30 percent to 18 percent (Hill, Lawrence J., "Pricing Initiatives and Development of the Korean Power Sector: Policy Lessons for Developing Countries, " Energy Policy, April 1992, pp.344-354).
} 
operational and maintenance procedures were improved, and more funding was devoted towards preventing transmission and distribution losses.

At present, the efficiency of South Korea's thermal power plants (38\% on average) stands well above the average found in most developing countries. Similarly, T\&D losses in South Korea are quite low. With losses at only $6 \%$ in 1990, South Korea is on par with the industrialized world. ${ }^{29}$

The bulk of South Korea's efforts to manage demand have focused on industry. The government's first major foray into this realm occurred in 1977, when a pricing structure based on time-of-day electricity consumption was imposed on major industrial electricity users. ${ }^{30}$ The government has waged various other efforts as well. A voluntary program launched in 1990, for example, offered low electricity prices to industries willing to cease operations during the hours of peak electricity demand. ${ }^{31}$ KEPCO also began charging more per $\mathrm{kWh}$ in the summertime than at other times of year. The South Korean government recently announced a 1.71 trillion Won (US\$ 2.2 million) program aimed at improving energy-efficiency in manufacturing. Included in the program are plans to replace less efficient equipment, to upgrade manufacturing processes and to construct co-generation power plants. ${ }^{32}$

Historically, the government has placed little emphasis on the residential or commercial sectors as arenas for demand-side management. In the household sector electricity prices do rise alongside increased use and, in the commercial sector, KEPCO imposes higher electricity tariffs during the summer months than during other less electricity-intensive seasons. As of August 1991, however, the government had issued only minor efficiency standards for buildings and had no set standards for appliances. ${ }^{33}$ (Despite the government's non-interventionist stance, the efficiency of Korean refrigerators and color television sets improved substantially between 1980 and 1985.$)^{34}$ Nonetheless, the particularly rapid electricity growth rates of the late 1980 s and early 1990s, coupled with a dwindling reserve margin, have prompted more interest in promoting efficiency in households and businesses. The Ministry of Energy and Resources recently has been negotiating with Korean appliance makers over the possibilities of developing efficiency standards. Air conditioning, the Ministry's main area of concern, accounts for an estimated $20 \%$ of electricity demand during the summer and can have a devastating impact on

\footnotetext{
${ }^{29}$ Meyers, Stephen and Campbell, Charles, Trends in Electricity Demand and Supply in the Developing Countries, 1980-1990, Lawrence Berkeley Laboratory, Berkeley, CA, November 1992.

${ }^{30}$ Hill, op cit., Ref. 28.

${ }^{31}$ Clifford, Mark, "Power Struggle," Far Eastem Economic Review, August 23, 1990, p.52.

so "South Korea to Launch Energy-Saving Program," Asian Energy News, Vol. 2, No. 10, October 1992, p.6.

${ }^{33}$ Clifford, op cit., Ref. 15.

36 Meyers, S., Tyler, S., Geller, H., Sathaye, J. and Schipper, L., Energy Efficiency and Household Electric Appliances in Developing and Newly Industrialized Countries, LBL-29678, Lawrence Berkeley Laboratory, Berkeley, CA, December 1990.
} 
already sparse electricity reserves. The growing use of air conditioning contributed largely to KEPCO's record high peak of 19,000 MW in the summer of 1991. ${ }^{35}$ The Ministry's current plans focus on the development of a system for rating the efficiency of air conditioners and two other major electricity-consuming products, refrigerators and lights. The rating system eventually might come to encompass a wider set of appliances and apply tighter standards. ${ }^{36}$

In the short run, the Ministry has had to rely on restrictive conservation measures. For the past two summers, the government has urged cutbacks in the use of air conditioning, elevators, escalators and other electricity-consuming activities. In the summer of 1992, offices were instructed not to allow their thermostats to drop below $28^{\circ} \mathrm{C}\left(82^{\circ} \mathrm{F}\right.$ ). (In a conciliatory effort, the Prime Minister's office reportedly provided daily supplies of ice cream to each of the 800 employees in Seoul's main government buildings.) Similarly, cooling restrictions were placed on subways. ${ }^{37}$

\subsection{Conclusion}

The South Korean government's power development plan calls for continued expansion of nuclear power (an addition of $8.1 \mathrm{GW}$ in 1991-2001) and coal-fired capacity (an addition of $12.4 \mathrm{GW}$ ). Installed capacity is expected to rise from $21.1 \mathrm{GW}$ in 1991 to $46.9 \mathrm{GW}$ in 2001 . After 2001, the construction of nuclear plants is expected to continue, while that of coal-fired capacity is expected to decline. The plan also includes a substantial increase in LNG-fired capacity over the 15 -year period.

The increase in capacity seems manageable, given KEPCO's competence and relatively sound financial situation. However, rising costs and public opposition may present barriers to the government's ambitious plans for expanding the role of nuclear power. Coal faces problems as well, which is likely to lead the government to place greater emphasis on clean-coal technologies over the long run. Combined with the recent erosion of KEPCO's reserve margin, the challenges on the supply side have galvanized greater interest in demand-side efficiency improvements. While South Korea uses electricity much more efficiently than most other developing countries, there is great potential for improvement that presently remains untapped.

\footnotetext{
${ }^{35}$ In contrast, KEPCO's winter peak that year was 18,000 MW (IEA, op cit., Ref. 1).

${ }^{36}$ Paisley, Ed, "Hot Under the Collar," Far Eastem Economic Review, 13 August 1992, p.51.

I Ibid.
} 


\section{TAIWAN}

\subsection{Introduction ${ }^{1}$}

Taiwan's emergence as a "newly industrialized country" during the 1980s was marked by simultaneously rapid increases in electricity consumption and GDP. Household incomes rose substantially, spurring widespread purchases of electricity-consuming appliances. ${ }^{2}$ The expansion of the service sector, and in particular the growing use of air conditioning in Taiwan's warm climate, led to especially rapid growth in commercial electricity demand. While the industrial sector continues to consume over half of Taiwan's public electricity supply, as the economy matured during the past decade, growth rates of industrial electricity demand slowed considerably (Table 6-1).

Taiwan Power Company (Taipower), a primarily government-owned enterprise, ${ }^{3}$ generates and distributes Taiwan's public electricity supply. The utility serves a population of nearly 20 million spread across an area of 36,000 square kilometers, including the main island of Taiwan and a few small neighboring islands. Almost all Taiwanese households now have access to electricity.

Between 1980 and 1990, installed generating capacity rose at an average rate of $6.4 \%$ per year. During the latter half of the 1980 s, however, installed capacity rose at a sluggish pace of $1.1 \%$ per year. This near freeze in capacity expansion was the result of a planned slowdown following a period of intense power sector development.

Like some other resource-poor but technically advanced countries, Taiwan started to rely on nuclear facilities for power generation in the late 1970s to reduce reliance on oil imports. Taiwan's first nuclear power plant came on line in 1978. From that point forward, Taiwan pursued a capacity expansion strategy based primarily on nuclear and coal, lessening the reliance on imported oil. By 1985, the share of oil-fired plants in total installed capacity had fallen to $33 \%$, down from about $72 \%$ in 1977 .

Nuclear's share in installed capacity remained relatively stable from 1985, when the last nuclear facility commenced operation, through 1990. In 1991, nuclear plants accounted for an equal share of Taiwan's $18.4 \mathrm{GW}$ of installed capacity as did oil-fired facilities, at $28 \%$. Coalfired and hydroelectric facilities accounted for $26 \%$ and $14 \%$ respectively. Gas-fired plants accounted for the remainder (Table 6-1).

\footnotetext{
1 Unless otherwise noted, the background data were drawn from: Taiwan Power Company (Taipower), Power Development Department, Long Range Power Development Program (1991-2001), Taipei, Republic of Chins, October 1991.

${ }^{2}$ Taiwanese households have among the highest saturations of electric appliances in developing Asia. In 1989, 100\% of all households had lighting, 92\% had televisions, $88 \%$ had refrigerators and $71 \%$ had clothes washers. The saturation of air conditioners, an indicator with particularly significant implications for electricity consumption, reached 29\% in 1989 (Ministry of Economic Affairs, Taiwan Energy Statistics, May 1991).

${ }^{3}$ The central and regional governments retain $92 \%$ of Taipower's stock; private investors hold the remaining shares.
} 
Table 6-1. Public Installed Capacity, Electricity Generation and Consumption in Taiwant

\begin{tabular}{|c|c|c|}
\hline & 1991 & $\begin{array}{l}\text { AAGR } \\
1980-90 \\
\end{array}$ \\
\hline Installed Capacity (MW) & $18383(100.0 \%)$ & $6.4 \%$ \\
\hline Hydro & $2562(13.9 \%)$ & $6.3 \%$ \\
\hline Nuclear & $5144(28.0 \%)$ & $15.0 \%$ \\
\hline Thermal & $10677(58.1 \%)$ & $3.7 \%$ \\
\hline Coal & $4725(25.7 \%)$ & $14.1 \%$ \\
\hline Oil & $5204(28.3 \%)$ & $-1.3 \%$ \\
\hline Gas & $748 \quad(4: 1 \%)$ & b \\
\hline Generation (GWh) & $92851(100.0 \%)$ & $7.2 \%$ \\
\hline Hydro & $5508 \quad(5.9 \%)$ & $10.9 \%$ \\
\hline Nuclear & $35290(38.0 \%)$ & $14.9 \%$ \\
\hline Thermal & $52053(56.1 \%)$ & $3.5 \%$ \\
\hline Coal & $24857(26.8 \%)$ & $12.2 \%$ \\
\hline Oil & $24529(26.4 \%)$ & $-1.4 \%$ \\
\hline Gas & $2667(2.9 \%)$ & b \\
\hline Consumption (GWh) & $91170(100.0 \%)$ & $7.3 \%$ \\
\hline Industrial $^{\mathbf{c}}$ & $53322(58.5 \%)$ & $5.6 \%$ \\
\hline Residential & $18233(20.0 \%)$ & $8.0 \%$ \\
\hline Commercial/Others & $17426(19.1 \%)$ & $13.0 \%$ \\
\hline Agriculture & $1759(1.9 \%)$ & $8.2 \%$ \\
\hline Transportation & $429 \quad(0.5 \%)$ & $3.6 \%$ \\
\hline
\end{tabular}

Notes: a. In 1990, industries possessed $1881 \mathrm{MW}$ of installed capacity and generated $4718 \mathrm{GWh}$ of electricity. ${ }^{4}$

b. LNG was introduced into the electricity $\operatorname{mix}$ in 1990 .

c. Includes energy sector.

Source: 1991 data from: Ministry of Economic Affairs, Energy Statistical Data Book 1991, March 1992. Growth rates based on Ministry of Economic Affairs, Taiwan Energy Statistics, various years.

- Ministry of Economic Affairs, Energy Commission, Taiwan Energy Statistics 1990, May 1991. 
While the growth of capacity stalled in the late 1980 s, electricity generation experienced an opposite trend. After a decade of robust growth (12\% per year between 1970 and 1980), generation increased at an average rate of only $5.2 \%$ per year between 1980 and 1985 , due primarily to an economic slowdown. During the late 1980s, electricity generation growth rates took off once more, largely as a result of the unexpectedly rapid pace of economic expansion. Generation growth averaged $9.3 \%$ per year between 1985 and 1990 . As a result of the paralysis in installed capacity in the late 1980s, Taipower shifted an increasing portion of the generation burden onto coal and oil. Nuclear provided 38\% of total generation in 1991, down considerably from 1985. Coal and oil each generated about one-quarter of the 1991 total and hydro generated about $6 \% .^{5}$

As a whole, electricity generation expanded more rapidly than installed capacity during the past decade -- a situation which increasingly raised concerns about the possibilities of electricity shortages. ${ }^{6}$ Peak demand rose even more rapidly than generation in the late 1980 s, underscoring the need for a sufficient reserve base. Between 1985 and 1990, peak demand increased at an average annual rate of $10.7 \%$, reaching an all time high of $14,511 \mathrm{MW}$ in August 1990. While in 1985 Taipower had maintained an extremely high reserve margin of $55 \%$, the August peak pushed the previously high surplus down to $7.4 \%$.

\subsection{Resources for Electricity Generation}

Due to the scarcity of indigenous energy resources, imported fuels sustain the bulk of the nation's electricity production.

Hydro, Taiwan's only substantial domestic electricity resource, accounts for about $15 \%$ of the nation's installed capacity. Most existing hydro plants are located away from the highest load centers in Taiwan's mountainous central and northern regions.

Taiwan also has minimal coal reserves. In 1988, Taiwan produced 1.2 million metric tons of coal, equalling about $7 \%$ of the total supply. Increasingly, Taiwan has turned away from indigenous coal resources due to the limited supplies, high costs of mining and the stiff competition posed by imported coal.

\footnotetext{
' Presently, Taipower satisfies the majority of the base load demand with nuclear, coal and run-of-the-river hydro, three options characterized by comparatively low operating costs. Oil-fired steam plants, combined-cycle facilities and pondage hydro typically are designated for intermediate load generation. Storage and pumped storage hydro and gas-turbine facilities are reserved for the peak load.

"Moore, Jonathan, "Joining the Fan Club: Taiwan Faces Summer of Power Shortages," Far Eastem Economic Review, Vol. 143, No.13, March 30, 1989, pp.46-47.
} 


\subsection{Forecast of Electricity Demand?}

Taipower's Long Range Power Development Program, issued in October 1991, includes several load forecasts. The projections are all based on the assumption that GDP rises by $7.2 \%$ per year between 1991 and 1996 and then drops slightly to an average of $6.5 \%$ per year between 1997 and 2001. The utility chose the "moderately high growth" scenario as the most likely of the options considered. This scenario, presented below, incorporates load management measures.

According to the scenario, electricity generation rises more slowly than GDP over the 10-year period (Table 6-2). This pattern is consistent with past trends, but represents a bit of a slowdown relative to the decade before; during the 1980s, GDP and public electricity generation rose at average annual rates of $7.3 \%$ and $6.8 \%$ respectively. Peak load increases more rapidly than average load, reflecting the greater use of air conditioning and continued changes in the characteristics of other appliances. ${ }^{8}$ Electricity generation reaches a total of 153 TWh in 2001, an almost two-fold increase relative to 1990.

Table 6-2. Taiwan's Projection of Electricity Supply and Demand

\begin{tabular}{|c|c|c|c|c|c|c|}
\hline & 1990 & 1991 & 1996 & 2001 & $\begin{array}{c}\text { AAGR } \\
1991-96\end{array}$ & $\begin{array}{c}\text { AAGR } \\
1996-01\end{array}$ \\
\hline Electricity Supply (GWh) ${ }^{b}$ & 80150 & 84951 & 115668 & 153553 & $6.8 \%$ & $5.5 \%$ \\
\hline Peak Load (MW) & 14511 & 15321 & 21228 & 28568 & $6.7 \%$ & $6.1 \%$ \\
\hline Average Load (MW) & 9150 & 9698 & 13168 & 17529 & $6.3 \%$ & $5.9 \%$ \\
\hline
\end{tabular}

Notes: a. Actual

b. Excludes energy for pumped storage.

Although the projections indicate a slight decline in the future growth of electricity generation relative to the past, some observers wonder whether the projected rates of growth might be too high. The decline of energy-intensive industries, the growing use of co-generated power and the transition to a services-oriented economy could all serve to moderate the growth of electricity in Taiwan's future to levels lower than Taipower's projections indicate. ${ }^{9}$

On the other hand, Taipower's past projections have erred in the opposite direction. Electricity demand grew far more rapidly in the late 1980s than the utility had projected. Since

\footnotetext{
${ }^{7}$ Unless otherwise noted, all data on electricity demand forecast and power sector development plans were drawn from Taipower, op cit., Ref. 1.

- During the past decade, Taiwanese houscholds have turned to larger and more energy-consumptive devices. For example, in 1987 over $16 \%$ of all Taiwanese households had refrigerators larger than 250 liters versus only 11 percent in 1980 (Meyers, S., Tyler, S., Geller, H., Sathaye, J. and Schipper, L., Energy Efficiency and Household Electric Appliances in Developing and Newly Industrialized Countries, LBL29678, Lawrence Berkeley Laboratory, Berkeley, CA, December 1990). The scenario assumes this pattern towards larger and more energyconsumptive appliances continues.

9 Goldstein, Carl, "Nuclear Qualms," Far Eastem Economic Review, July 4, 1991, pp.39-42.
} 
Taiwan's economy is heavily dependent on exports, industrial output will be strongly shaped by trends in the world economy.

\subsection{Plans for Power Sector Development}

Taipower's Long-Range Power Development Program for the years 1991 through 2001 shows a doubling of installed capacity. Gas (LNG) and coal account for $41 \%$ and $37 \%$ of the net growth in capacity respectively. Nuclear and hydro each comprise about $10 \%$ of the net increase.

Supplanted primarily by coal and gas, nuclear witnesses a substantial decline in its share of installed capacity, from $28 \%$ in 1991 to $19 \%$ in 2001 (Table 6-3). In an even more dramatic shift, oil's share falls to half of its 1991 value by the year 2001 (Figure 6-1).

Table 6-3. Taipower Plans for Installed Generating Capacity and Electricity Generation

\begin{tabular}{|c|c|c|c|c|}
\hline & $1991^{\prime}$ & 1996 & 2001 & $\begin{array}{c}\text { AAGR } \\
1991-2001\end{array}$ \\
\hline Installed Capacity (MW) & $18380(100.0 \%)$ & $26414(100.0 \%)$ & $37471(100.0 \%)$ & $7.4 \%$ \\
\hline Hydro & $2562(13.9 \%)$ & $4421(16.7 \%)$ & $4824(12.9 \%)$ & $6.5 \%$ \\
\hline Nuclear & $5144(28.0 \%)$ & $5144(19.5 \%)$ & $7144(19.1 \%)$ & $3.3 \%$ \\
\hline Thermal & $10677(58.1 \%)$ & $16849(63.8 \%)$ & $25503(68.0 \%)$ & $9.1 \%$ \\
\hline Coal & $4725(25.7 \%)$ & $6972(26.4 \%)$ & $11822(31.5 \%)$ & $9.6 \%$ \\
\hline Oil & $5204(28.3 \%)$ & $6126(23.2 \%)$ & $5091(13.6 \%)$ & $-0.2 \%$ \\
\hline Gas & $748 \quad(4.1 \%)$ & $3751(14.2 \%)$ & $8590(22.9 \%)$ & $27.6 \%$ \\
\hline Generation (GWh) & $93238(100.0 \%)$ & $120432(100.0 \%)$ & $157559(100.0 \%)$ & $5.4 \%$ \\
\hline Hydro & $5508 \quad(5.9 \%)$ & $9139(7.6 \%)$ & $10526(6.7 \%)$ & $6.7 \%$ \\
\hline Nuclear & $35290(38.0 \%)$ & $31498(26.2 \%)$ & $43666(27.7 \%)$ & $2.2 \%$ \\
\hline Thermal & $52053(56.1 \%)$ & $79795(66.2 \%)$ & $103367(65.6 \%)$ & $7.1 \%$ \\
\hline Coal & $24857(26.8 \%)$ & $44204(36.7 \%)$ & $66359(42.1 \%)$ & $10.3 \%$ \\
\hline Oil & $24529(26.4 \%)$ & $26849(22.3 \%)$ & $7083(4.5 \%)$ & $-11.7 \%$ \\
\hline Gas & $2667(2.9 \%)$ & $6882(5.7 \%)$ & $28065(17.8 \%)$ & $26.5 \%$ \\
\hline Purchased Co-generation & $387(0.5 \%)$ & $1860(1.5 \%)$ & $1860(1.2 \%)$ & $17.0 \%$ \\
\hline
\end{tabular}

Note: a. Actual

Sources: 1991 data from Ministry of Economic Affairs, Energy Statistical Data Book 1991, March 1992. All other data from Taipower October 1991. 


\section{Taiwan Power Development Plans Installed Capacity}

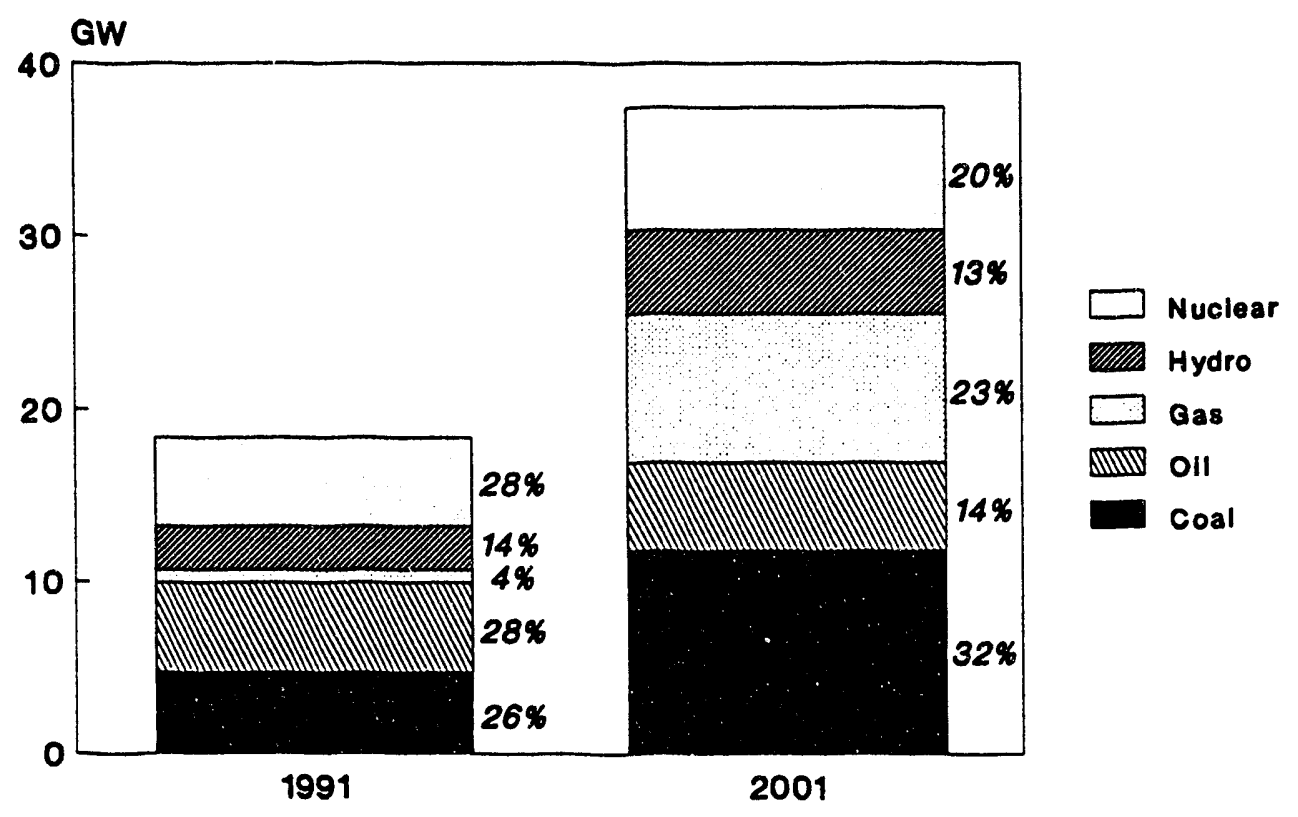

Figure 6-1 
The relatively minor expansion of nuclear capacity reflects a significant change from earlier visions of nuclear's role in the Taiwanese power base. In the 1970s, before environmental opposition to nuclear plants arose as an obstacle in Taiwan, the utility spoke of having 20-24 nuclear reactors, with four to six units at each site, operating by the year $2000 .^{10}$ Presently, Taipower has six nuclear units; by 2001 , the utility plans to add only two more units with a combined installed capacity of $2000 \mathrm{MW}$.

In terms of electricity generation, nuclear witnesses the slowest increase of all sources aside from oil between 1991 and 2001. Generation from oil grows at an average rate of $3 \%$ per year between 1991 and 1995. Between 1995 and 2001, however, oil-fired electricity drops at an average annual rate of $20.7 \%$. Bv 2001 , the share of power generated from oil stands at about one-fifth its 1991 value. Nuclear's share of electricity generation falls to $28 \%$, down from $38 \%$ a decade earlier. Coal generation comes to dominate the mix by 2001 , with a $42 \%$ share of the total. Gas also takes on a substantial role. Taipower also expands the role of purchased power from cogeneration during the next decade.

What takes place between 1991 and 2001, according to the plan, is a dual shift, with coal taking on more of the role pricviously held by nuclear and gas shouldering the load formerly carried by oil (Figure 6-1). The projections for fuel consumption for electricity generation illustrate Taiwan's continued reliance on energy imports -- although the shift to imported coal and gas would alleviate some of the previous security problems imposed by oil imports. The projections foresee oil consumption for electricity generation falling significantly between 1990 and 2001 (Table 6-4). In contrast, the coal requirement multiplies over three-fold and the LNG requirement over twenty-fold. The ner $d$ for uranium rises by about one-third the 1990 level.

Table 6.4. Fuel Consumption for Electricity Generation

\begin{tabular}{lrr}
\hline Primary Fuel & 1990 & 2001 \\
\hline \hline Coal $\left(10^{3}\right.$ tons $)$ & 7964 & 24842 \\
Oil $\left(10^{3} \mathrm{KL}\right)$ & 5292 & 1938 \\
Heavy oil & 5013 & 1927 \\
Light oil & 279 & 11 \\
LNG $\left(10^{3}\right.$ tons $)$ & 210 & 4500 \\
Yellow Cake $\left(10^{3} \mathrm{lbs}\right)$ & 2048 & 2725 \\
\hline \hline
\end{tabular}

One of the most pressing issues for Taiwan's energy planners is the nation's quickly diminishing capacity surplus. Taipower's power development plan foresees the reserve margin rising to $22.4 \%$ by 2001 -- a leval still below the ideal margin, but far better than Taiwan has

\footnotetext{
10 Ibid.
} 
seen in recert years. In the near term, power shortages still may plague Taiwan. Taipower predicted that the reserve margin would fall to $4.8 \%$ in 1991 , an even lower level than in 1990.

Taipower has long designated energy security as a major priority in energy planning. In the current power development plan, the utility emphasizes the need to diversify the electricity base and to increase the role of domestic resources in power generation (and in this case Taipower considers nuclear power to be "domestic").

The composition of Taipower's new plant portfolio exhibits a major aspect of the diversification strategy. Taipower plans to expand one existing combined-cycle project and to initiate six new combined-cycle projects. Most of these new units will be designed to accommodate natural gas. In addition, some of the other new thermal units will be fitted with dual systems that can run on either gas or oil -- a strategy which the utility hopes will protect the power sector from sudden fluctuations in oil prices.

\subsection{Financial Issues}

Taipower's long-term program incorporates a number of measures aimed at minimizing costs. The utility hopes to continue maintaining a regional power supply system -- a strategy which has cut down on losses and transmission equipment costs in past years. Taipower's other priorities include rationalizing investment and operation and maintenance costs by standardizing the size of individual units; developing multiple units at each site; and maintaining a profit level sufficient to cover debt service.

Advocates of nuclear power in Taiwan argue that nuclear energy is less expensive than other options. An economic analysis conducted by the Chung-Hua Institute for Economic Research in 1986 found that, on a project basis, nuclear power plants would have a slightly lower levelized cost per $\mathrm{kWh}$ than coal-fired plants without desulfurization, and a significantly lower cost than coal-fired plants with desulfurization. " When simulated from a system perspective, however, the difference in overall future average levelized cost between the nuclear and coal cases is very small. And if the nuclear plants operate at less-than-expected capacity (a $65 \%$ capacity factor was assumed), or nuclear back-end costs (waste disposal and plant decommissioning) turn out to be higher than assumed, the difference might disappear. In the past, Taipower has had to shut down various nuclear facilities for extended periods of time to make repairs. Taipower assumes that these "back-end" expenditures will multiply in the future. ${ }^{12}$

\footnotetext{
"Hsu, George J.Y. and Chen, Tser-yieth, "An Economic Analysis on the Long-term power Development Alternatives in Taiwan," Proceedings, Thirteenth Annual International Conference, International Association of Energy Economics, 1991.

12 In 1990 back-end expenses accounted for 5.3 percent of the cost/kWh. In Taipower's cost projections for its fourth nuclear plant, the utility has allocated 9.6 percent of the cost/kWh to back-end activities (Goldstein, Carl, op cit., Ref. 9).
} 


\subsection{Environmental Considerations}

The current development plan includes the construction of Taiwan's fourth nuclear power project at Yenliao, a site located on the country's northeastern coast 41 kilometers from Taipei. Questions still remain, however, as to whether this planned project will come to pass. The construction of the Yenliao project, first proposed in 1980, has witnessed repeated delays over the past 12 years, largely due to strong public opposition. In May 1991, the government called in riot police when a group of several thousand demonstrators led by the mayor of Taipei County showed up with a construction wrecking crew to destroy the temporary structures at the Yenliao site. ${ }^{13}$ While in 1988 the utility had slated the first two nuclear units to commence operation in 1993-94, according to Taipower's latest plan, both units have been pushed back until 1999-2000.

Although certain complaints currently being lodged against nuclear power are specific to the Yenliao plant -- such as its proximity to Taipei -- opposition to nuclear in general has remained strong, fueled in part by a series of mishaps at the nation's existing nuclear facilities over the past few years. A turbine generator caught fire at the Mannshan nuclear facility in July 1985, forcing the station to shut down for a prolonged period. In September 1985, radiation leaks were discovered at the Chinshan plant. The radiation leaked into the atmosphere for several weeks before Taipower remedied the problem. An internal Taipower review carried out at that time revealed other safety problems at the plant as well. In 1988, an engineer working at the Chinshan station publicly announced additional dangers he had uncovered at the plant. Taipower has taken some steps to try to improve plant safety since these incidents occurred. Other commonly cited problems associated with nuclear power development include Taiwan's location in a highly sensitive tectonic zone and inadequate plans for radioactive storage. ${ }^{14}$

Many of the accidents have been linked with accusations of corruption and mismanagement on the part of Taipower. In a 1988 court case filed against Taipower, Taiwan Consumers' Foundation charged that the utility had been selling radioactive scrap metal to certain industries. Coupled with the scandal regarding Taipower's purchases of over-priced coal $^{15}$ and the various technical problems at existing plants, this charge has served to undermine the public's trust in the utility and its decisions.

\footnotetext{
${ }^{13}$ Ibid.

14 Goldstein, Carl, "Core Problems," Far Eastem Economic Review, July 4, 1991, pp.40-41.

${ }^{15}$ In 1988, the Taiwanese government's oversight group investigated allegations that Taipower authorities had been purchasing over-priced coal from U.S. companies in return for kickbacks. The U.S. coal, which was priced on average 20 percent above world market prices, accounted for 60 percent of Taipower's coal purchases between 1980 and 1987 - costing the Taiwanese government as much as $\$ 100$ million more than would have otherwise been required. Because Taipower officials signed long-term contracts with the U.S. coal companies, however, Taiwan may be obligated to continue spending far more than necessary on coal imports for the next few years (Moore, Jonathan, "Nuclear Shutdown: Public Outcry Forces Taiwan to Shelve Construction of Power Plant, " Far Eastem Economic Review, June 2, 1988, pp.62-63).
} 
Opposition has not been reserved solely to the construction of new nuclear plants. Land acquisition for all new plants has surfaced as a significant problem -- one which takes on greater importance in light of the strong likelihood of shortages over the next decade and the current lack of space for additional units even on those sites currently holding thermal facilities. ${ }^{16}$

\subsection{Electricity Supply and End-Use Efficiency}

The efficiency of Taiwan's thermal power plants surpasses that of most other developing nations. In fact, Taiwan's average efficiency of 37\% in 1990 was higher than in many industrialized countries. The relatively recent installation of much of Taiwan's generating capacity (about $70 \%$ of Taiwan's thermal capacity was installed after 1975) contributes to this high efficiency.

Taiwan maintains an extremely efficient transmission and distribution system, due in part to the geographical set up of the power sector. Regional facilities serve the electricity needs of surrounding communities, thereby keeping transmission losses to a minimum. In 1990, transmission and distribution losses were down to 7\%, putting Taiwan's performance on par with most industrialized countries.

Observers suggest that conservation measures could offer great savings, particularly in the industrial sector, which accounts for the bulk of Taiwan's electricity consumption. According to Edgar Lin, an environmental scientist at Taiwan's Tunghai University, relatively simple measures could offer savings as high as $20 \%$ in the industrial sector. ${ }^{17}$

Taipower recently instituted time-of-day pricing to try to smooth out the industrial load, but otherwise has done little in the area of demand-side management. The Energy Management Law, passed in 1980, did set mandatory efficiency standards for buildings, household appliances and other energy-using devices, but due to poor enforcement, the level of compliance has remained quite low. There has been technical improvement, however; for example, new window air conditioners saw efficiency improvements averaging $40 \%$ between 1981 and $1988 .{ }^{18}$

\subsection{Conclusion}

Once viewed with great hope, nuclear power has fallen from grace in the eyes of many power planners in both industrialized and developing countries. Safety hazards, rising costs and public opposition all have contributed to less optimistic projections of nuclear's role in future

\footnotetext{
${ }^{16}$ Taipower, op cit., Ref. 1.

${ }^{17}$ Moore, Jonsthan, op cit., Ref. 15.

13 Hsueh, L., "An Evaluation of Taiwan's Energy Conservation Policy," Proceedings, Eleventh Annual International Conference, International Association for Energy Economics (Caracas, Venezuela), June 1989.
} 
electricity generation. Taiwan's power development plans reflect this international trend. In 1985, Taiwan generated $52 \%$ of its electricity from nuclear sources; only two other countries worldwide boasted a larger share of nuclear in electricity generation. According to Taipower's program, nuclear's share in electricity generation will fall to under $28 \%$ by 2001 .

In light of the projected nuclear decline, the utility foresees a powerful shift towards electricity generation from coal and natural gas. From an environmental perspective, LNG represents the more preferable option. The prospect of a substantial increase in coal-generated electricity has serious implications in terms of local air quality, and also will contribute to rising greenhouse gas emissions. However, LNG is also a relatively expensive solution to Taiwan's energy problems.

The financial and environmental obstacles associated with the energy alternatives currently available to Taiwan highlight the potential role for energy-efficiency improvements in Taiwan's power sector. To date, Taipower has had limited experience in the realm of DSM and has not shown signs of moving in that general direction. By embarking on a concerted effort to improve end-use efficiency, Taiwan could reap substantial electricity savings and cut back on the quantities of coal Taipower currently projects will be necessary to meet future needs. 


\section{THALLAND}

\subsection{Introduction}

During the past decade of rapid economic expansion, Thailand has witnessed among the fastest rates of electricity growth in developing Asia. The recent economic boom led to annual increases in electricity sales averaging $15 \%$ between fiscal year (FY) 1986 and FY 1991. ${ }^{1}$ To meet the heightened demand, the Electricity Generating Authority of Thailand (EGAT), ${ }^{2}$ a stateowned company which historically has maintained a virtual monopoly on Thailand's public electricity generation, has had to expand its electricity-generating capacity rapidly. Between 1982 and 1991, EGAT's installed capacity rose from $4.1 \mathrm{GW}$ to $9.6 \mathrm{GW}$. In 1991 , electricity generation reached 49,225 GWh and peak demand rose to 8,045 MW.

Throughout the 1970s oil and hydro served as the mainstay of Thailand's power base. Largely in response to the government's promotion of domestic resources following the oil price shocks of 1979-80, EGAT greatly diminished the share of installed capacity provided by oil-fired plants during the 1980s. EGAT only moderately expanded its installed hydroelectric capacity - largely due to widespread public opposition to hydro development based on possible environmental impacts and resettlement requirements. In contrast, lignite-fired, combined-cycle and gas-/oil-fired plants proliferated (Table 7-1).

As a result of this shift, the amount of electricity generated from lignite and natural gas rose over seven- and four-fold respectively between 1982 and 1991, while electricity generation from oil resources less than doubled. Generation from hydro sources expanded by only $2 \%$ per year over the same time period. At $40 \%$, natural gas accounted for the single largest share of electricity generation in 1991.

The industrial sector accounted for the largest share of public electricity consumption at $47 \%$ in 1991 , followed by the commercial sector with $25 \%$ and the residential sector with $21 \% .^{3}$ The share of Thai households with access to electricity has surged over the past decade - from $41 \%$ in 1981 to $75 \%$ in 1991 -- contributing to the increase in residential electricity demand. While electricity consumption has climbed rapidly in every sector, the commercial sector witnessed the fastest growth in recent years.

\footnotetext{
${ }^{1}$ Unless otherwise specified, the background data were drawn from: Electricity Generating Authority of Thailand (EGAT), General Information EGAT Power Development Plan (PDP 92-01), July 1992. The term Fiscal Year (FY) describes the 12-month period ending in September. Thus, FY 1991 refers to October 1, 1990 through September 30, 1991. Throughout this section all years refer to fiscal years.

${ }^{2}$ In addition to electricity sales to private industries and various direct customers, EGAT sells bulk electric power to two major electricity distributors - the Metropolitan Electricity Authority (MEA), which distributes electricity to greater Bangkok and two outlying suburbs, and the Provincial Electricity Authority (PEA), which provides services to other parts of the country. An enormous enterprise with strong political influence, EGAT had the largest assets of all Thailand's state businesses as of 1989 (US\$ 4.8 billion) and produced the third largest revenues (Handley, Paul, "Power Struggle," Far Eastem Economic Review, June 27, 1991, pp.51-52).

${ }^{3}$ Public utilities, government institutions, non-profit organizations, agricultural pumping, street lighting and a few other miscellaneous end uses accounted for the remainder.
} 
Table 7-1. Public Installed Capacity and Electricity Generation in Thailand"

\begin{tabular}{|c|c|c|}
\hline & FY 1991 & $\begin{array}{l}\text { AAGR } \\
1982-91\end{array}$ \\
\hline Installed Capacity (MW) & $9639(100.0 \%)$ & $10.1 \%$ \\
\hline Hydro & $2429(25.2 \%)$ & $6.5 \%$ \\
\hline Thermal, by type & $7210(74.8 \%)$ & $11.6 \%$ \\
\hline Oil-fired & $268 \quad(2.8 \%)$ & $-9.7 \%$ \\
\hline Gas-/Oil-fired & $2580(26.8 \%)$ & $11.4 \%$ \\
\hline Lignite-fired & $2059(21.4 \%)$ & $24.6 \%$ \\
\hline Combined cycle & $2037(21.1 \%)$ & $15.0 \%$ \\
\hline Gas turbine & $238 \quad(2.5 \%)$ & $5.3 \%$ \\
\hline Diesel & $29(0.3 \%)$ & $-1.1 \%$ \\
\hline Generation (GWh) & $49225(99.9 \%)^{b}$ & $12.6 \%$ \\
\hline Hydro & $4413(9.0 \%)$ & $2.0 \%$ \\
\hline Thermal, by fuel & $44159(89.6 \%)$ & $15.3 \%$ \\
\hline Lignite & $12514(25.4 \%)$ & $24.6 \%$ \\
\hline Oil & $11893(24.1 \%)$ & $7.6 \%$ \\
\hline Gas & $19752(40.1 \%)$ & $17.5 \%$ \\
\hline Purchase & $652(1.3 \%)$ & $-0.8 \%$ \\
\hline Public Electricity Saies ${ }^{c}$ & $42559(99.9 \%)^{b}$ & $13.0 \%$ \\
\hline Industrial & $19887(46.7 \%)$ & $12.8 \%$ \\
\hline Residential & $8943(21.0 \%)$ & $12.9 \%$ \\
\hline Commercial & $10719(25.2 \%)$ & $14.4 \%$ \\
\hline Other' & $3010 \quad(7.0 \%)$ & $10.1 \%$ \\
\hline
\end{tabular}

Notes: a. Does not include self-producers.

b. Does not add up to $100 \%$ due to rounding.

c. Projected values.

d. Other includes public utilities, government institutions, nonprofit organizations, agricultural pumping, street lighting, etc.

Sources: Capacity and generation data directly from or calculated from Electricity Generating Authority of Thailand (EGAT), General Information EGAT Power Development Plan (PDP 92-01), July 1992. Electricity sales data from Thailand Load Forecast Working Group, Load Forecast for the Thailand Electric System. Volume 1. Load Forecast Summary, September 1991.

During the 1980s, Thailand confronted the dramatic growth of electricity demand by substantially expanding EGAT's installed capacity. Increasingly, however, obstacles have arisen to the construction of new electric power plants. In particular, objections from local residents, national NGOs and international agencies on social and environmental grounds have caused 
EGAT to modify existing power facilities and to delay and cancel planned power-generating stations. All signs point to continued high growth rates of electricity demand in coming years. Confronted with a burgeoning environmental movement and the growing capital requirements associated with expanding the power sector, the Thai government, with the aid of various international organizations, has recently agreed to embark on a comprehensive demand-side management program. This program -- the first of its kind in developing Asia -- could have a major influence on the future of the Thai power sector, not to mention the power sectors in neighboring developing nations.

\subsection{Resources for Electricity Generation ${ }^{4}$}

Imported energy -- and particularly imported petroleum -- fueled much of Thailand's growth through the early 1980s. In 1980, oil imports comprised $94 \%$ of the nation's primary energy supply. After experiencing the devastating consequences of the oil price shock of 197980 , however, the Thai government began to promote the development and use of indigenous energy sources. Through the exploitation of domestic gas, coal, hydro and petroleum reserves, Thailand successfully managed to diminish the share of imports in primary energy to $53 \%$ in 1988. In more recent years, however, imports have been on the upswing once again. As of 1990 , the share of imports in primary energy had risen to about $59 \%$-- a harbinger of a future in which external electricity-generating sources will come to play a more important role once again.

Thailand's minimal oil resources have contributed to its heavy dependence on imports. The nation possesses crude oil and condensate reserves totalling 1,150 million barrels. Recoverable reserves are estimated at 498 million barrels, half of which are proven reserves. Thailand produced 16 million barrels of crude oil and condensate in 1990.

Past ventures aimed primarily at identifying new reserves of oil have uncovered significant quantities of gas. According to current estimates, Thailand has approximately 19.25 thousand cubic feet (TCF) of natural gas reserves. Of this total, about 16.1 TCF are recoverable reserves and 8.6 TCF are proven reserves. ${ }^{5}$

Thailand has an estimated hydroelectric potential of $10.6 \mathrm{GW}$, only $2.4 \mathrm{GW}$ of which had been tapped as of 1991. Despite the extent of the untapped potential, environmental concerns and cost constraints are likely to hinder the exploitation of Thailand's remaining indigenous hydro resources in coming years.

In the face of an otherwise contracting domestic resource base, Thailand has had a great deal of success in unearthing new lignite supplies. According to 1992 estimates, geological

\footnotetext{
4Unless otherwise specified, resource data are from Electricity Generating Authority of Thailand (EGAT), General Information EGAT Power Development Plan (PDP 92-01), July 1992.

'Most of the nation's economically proven reserves of natural gas lie in 23 off-shore fields located in the Gulf of Thailand. Three on-shore sites located at Khorat Basin in northeastern Thailand possess the remainder.
} 
reserves of lignite total 2,069 million tons, about half of which are considered minable. ${ }^{6}$ As of 1991, lignite from the nation's richest site, Mae Moh (with estimated minable reserves of 812 million tons) fueled over $20 \%$ of the nation's electricity supply. The recent findings of a fiveyear exploratory project in Saba Yoi, a site located in the south, turned up the second largest lignite deposits in all of Thailand. Some observers feel that a strong potential exists for more discoveries in the future. ${ }^{7}$

The government's current plans include the development of the nation's first nuclearpowered electricity plant. Thailand possesses no known uranium resources.

Due to the impending dearth of indigenous resources for electricity generation, Thailand is looking increasingly towards establishing joint power projects with neighboring countries and importing energy. The Mekong River, which lines Thailand's borders with Myanmar, Cambodia and Laos, holds enormous hydroelectric potential. In the past political tensions have hindered joint ventures. As of 1988, however, the Mekong Committee, with financial backing from the United Nations Development Program and 12 bilateral aid agencies, began to reexamine the possibilities of constructing a series of dams with an installed hydroelectric capacity as high as $20,000 \mathrm{MW}$ to be shared amongst the four countries. Among the issues under discussion are the mitigation of environmental impacts and financing and pricing policies. ${ }^{8}$ In addition, the Thai government recently has begun to examine the possibilities of importing natural gas from Malaysia, Myanmar and Vietnam.

\subsection{Forecast of Electricity Demand'}

In 1991, Thailand's Load Forecast Working Group (LFWG) -- a body made up of representatives from EGAT, MEA, PEA, the National Energy Policy Office (NEPO), the National Energy Administration (NEA) and Thailand Development Research Institute (TDRI) - produced a long-term electricity load forecast through 2006 . The forecast assumes that Thailand's GDP grows particularly rapidly between 1992-96, at an average rate of $8.2 \%$ per year, due partially to the continued high exports of textiles and chemical and petrochemical products. GDP growth then gradually diminishes, falling to $7.5 \%$ per year between 1997-2001 and $6.3 \%$ per year between 2002-2006.

According to this projection, electricity sales rise from 47.9 TWh in 1992 to $144.4 \mathrm{TWh}$ in 2006 (Table 7-2). The average growth of electricity consumption peaks during the first four

\footnotetext{
6 About 82 percent ( 837 million tons) of the minable reserves can be found in the Lampang and Chiang Mai provinces near the northern tip of the country, while the remaining reserves (180 million tons) are located deep in the southern Krabi and Songkhla provinces (EGAT 1992).

' Kositchotethana, Boonsong, "Huge Lignite Deposits Found in the South," Bangkok Post Weekly, April 24, 1992.

'The Tides Foundation, "Harnessing the Mighty Mekong," World Rivers Review, September/October 1991, pp.6-8.

'All of the demand forecast data were drawn from Thailand Load Forecast Working Group, Load Forecast for the Thailand Electric System. Volume 1. Load Forecast Summary, September 1991.
} 
years (1992-96) at $10.3 \%$ per annum, and drops gradually thereafter. At no time do growth rates match the high levels of the late 1980 s.

Table 7-2. Projection of Public Electricity Sales and Peak Demand in Thailand, 1992-2006

\begin{tabular}{lccccc}
\hline & FY 1992 & FY 1996 & FY 2001 & FY 2006 & $\begin{array}{c}\text { AAGR } \\
\text { FY 1992-FY 2006 }\end{array}$ \\
\hline \hline Public Electricity Sales (GWh) & 47833 & 70855 & 104535 & 144.433 & $8.2 \%$ \\
Industrial & 22377 & 32700 & 48354 & 67172 & $8.2 \%$ \\
Residential & 10049 & 14794 & 21963 & 31018 & $8.4 \%$ \\
Commercial & 12169 & 19245 & 28940 & 39811 & $8.8 \%$ \\
Other & 3238 & 4116 & 5278 & 6432 & $5.0 \%$ \\
Peak Demand (MW) & 9000 & 13075 & 19000 & 25515 & $7.7 \%$ \\
\hline \hline
\end{tabular}

Notes: a. Other includes public utilities, government institutions, nonprofit organizations, agricultural pumping, street lighting, etc.

Driven by the further development of the service sector and, in particular, the everincreasing demand for air conditioning, electricity consumption grows most rapidly in the commercial sector. The residential sector witnesses the next highest rates of growth, spurred by increasing saturations of appliances in rural areas and a substantial increase in the overall number of electrified households.

The most substantial increases in electricity demand are projected to take place outside of the Bangkok Metropolitan Area. In 1991, MEA, the company which distributes electricity to the Bangkok Metropolitan Area, accounted for $46 \%$ of EGAT's electricity sales and PEA, Thailand's other distributor, accounted for about 50\% (EGAT's sales to direct customers made up the difference). By 2006, MEA's share falls to $41 \%$, while PEA's portion increases to $58 \%$. Government policies encouraging the establishment of industrial estates outside of Bangkok partially account for the more rapid growth rates in PEA areas, along with rising levels of electricity demand in rural households.

To meet demand, electricity generation expands over threefold during the 14-year period, from 55.5 TWh in 1992 to 166.9 TWh in 2006. The annual growth rates fall from an average of $10.2 \%$ per year between 1992 and 1996 to an average of $6.6 \%$ per year between 2001 and 2006.

The LFWG 1991 forecast shows the peak load increasing from 9,000 MW in 1992 to 25,515 MW in 2006.

During the last five years unexpectedly high rates of electricity growth have caused the LFWG to continually revise their projections upward. In 1988, LFWG raised the estimates 
issued in 1987. The new projections showed peak load rising to $7.44 \mathrm{GW}$ in 1991 and generation increasing to $45.06 \mathrm{TWh}$. As the actual numbers from 1991 reveal, even the revised projections were too low (see Table 7-1). Similarly, the estimates of peak load and electricity generation provided in the most recent 1991 projections for 2006 were 19 and $36 \%$ higher than the 1990 LFWG projections. ${ }^{10}$ While the latest adjustments may have contributed to a more realistic picture of future electricity demand in Thailand, the experience of recent years reveals that a great deal of uncertainty still exists.

\subsection{Plans for Power Sector Development ${ }^{11}$}

In 1992, EGAT developed four scenarios for future power development in Thailand. This section outlines the scenario EGAT deemed the most probable of the four. This projection assumes that Thailand does not successfully embark on a joint hydro project with Laos and does not import natural gas from Myanmar and Vietnam -- two options mentioned in section 1.2. The three scenarios not included here incorporate varying increases in imported natural gas and hydroelectricity from joint projects.

EGAT's power development plan provides projections for the power sector over the short-term and the long-term. One central theme characterizes EGAT's goals for the 1992-96 period: the need to diversify Thailand's power resource base. EGAT's short-term outlook focuses on expanding the use of domestic lignite and hydro when viable, substituting imported natural gas and liquefied natural gas (LNG) for fuel oil, and developing more imported coal-fired power facilities. EGAT's longer-term vision foresees a substantial increase in the use of imported coal, largely at the expense of oil and natural gas, and the construction of Thailand's first nuclear power facility.

According to the plan, installed generating capacity increases from $9.6 \mathrm{GW}$ in 1991 to $22.8 \mathrm{GW}$ in 1991 and $31.0 \mathrm{GW}$ in 2006 (Table 7-3) (Figure 7-1). EGAT plans to add $22.9 \mathrm{GW}$ of new generating capacity over the 15-year period and to retire existing plants with a capacity of $1.5 \mathrm{GW}$.

Gas-fired combined-cycle plants dominate the project portfolio during the first five years. Of the 5,305 MW of generating capacity to be developed in 1992-96, combined-cycle plants account for $43 \%$. During the 1997-2001 period, most of the added power comes from imported coal and oil/coal plants. Lignite and imported coal plants play the central role between 2002 and 2006. In addition, EGAT introduces $2000 \mathrm{MW}$ of nuclear power in the final cycle.

\footnotetext{
${ }^{10}$ The 1990 LFWG forecast for 2006 showed peak load rising to $21,499 \mathrm{MW}$ and electricity generation increasing to $122,482 \mathrm{GWh}$.

"EGAT, op cit., Ref. 4.
} 


\section{Thailand Power Development Plans Installed Capacity}

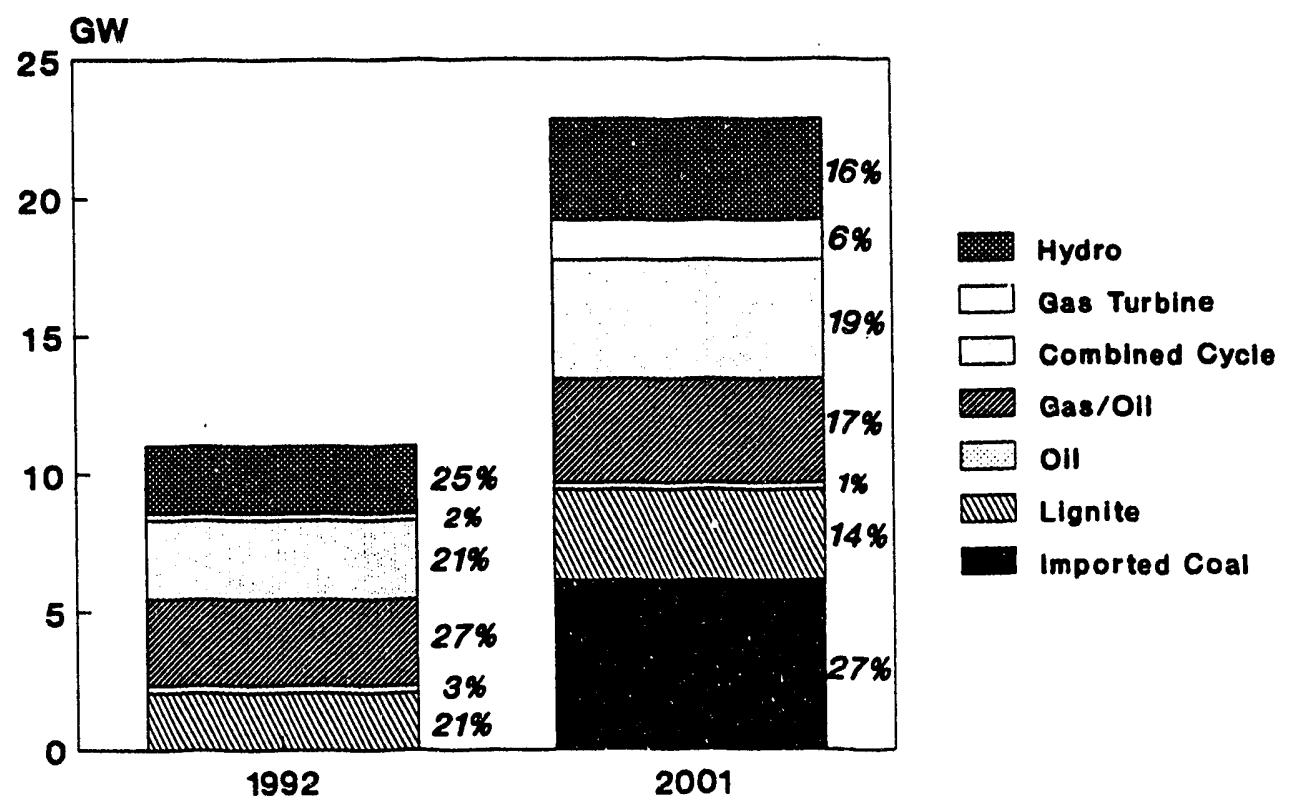

Figure 7-1 


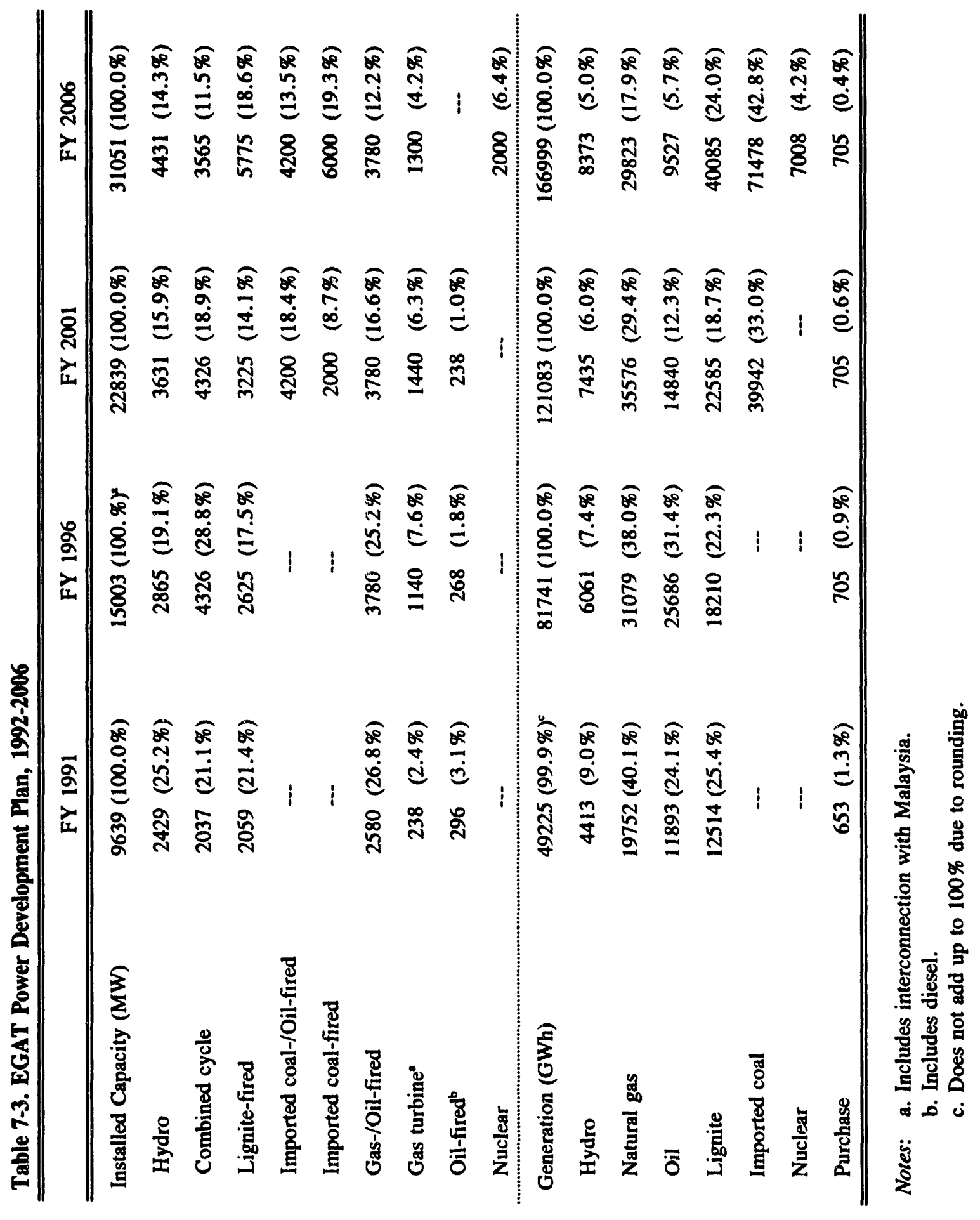


Overall, the three dominant plant types in Thailand as of 1992, hydro, gas-/oil-fired and combined-cycle facilities, which together accounted for $77 \%$ of installed capacity, come to comprise a far lesser role in the mix by 2006 -- about $38 \%$. Coal-based facilities -- plants running on lignite, imported coal and oil/imported coal -- come to form the backbone of Thailand's installed capacity.

EGAT's development plan partially reflects an attempt to have a more flexible power system able to adjust to fluctuations in the supply of elestricity-generating sources. Among the projects to be built over the next decade are four imported coal-fired units, Ao Phai 1-4, with a combined capacity of $2800 \mathrm{MW}$. After weighing the high costs of installing flue gas desulphurization mechanisms and other coal-related systems against the expense of importing low sulfur fuel oil, EGAT recently decided to power the Ao Phai plants with imported oil for a minimum of three years after their completion. Such a strategy will allow the utility to take advantage of relatively low oil prices in the short term and put off the cost of modifying the facilities to burn coal into the future.

The 1992 figures show natural gas and oil together fueling approximately two-thirds of Thailand's electricity generation. According to the projections, the combined role of these two fossil fuels falls to less than one-quarter of total generation by 2006 . Imported coal forms the mainstay fuel for electricity generation by 2006 , followed by lignite. Although the share of natural gas falls substantially over the 14-year period, gas still makes a notable contribution to electricity generation in 2006.

Fuel requirements for electricity generation expand considerably (Table 7-4). In the case of both natural gas and oil, however, the amount of fuel required peaks at the turn of the century, and drops thereafter. Indonesia recently agreed to supply Thailand with 500 million cubic feet of natural gas/day for a period of 25 years to support gas-fired power plants to be built on Thailand's eastern seaboard. The gas supply will be transported via a 700 kilometer sub-marine pipeline from the gas fields in Indonesia to the gas grid in the Gulf of Thailand. ${ }^{12}$

Table 7-4. EGAT's Fuel Requirements for Electricity Generation, 1992-1996

\begin{tabular}{lccccc}
\hline \multirow{2}{*}{ Fuel Type } & Units & \multicolumn{5}{c}{ Year } \\
\cline { 3 - 6 } & & FY 1992 & FY 1996 & FY 2001 & FY 2006 \\
\hline Natural Gas & $10^{6}$ SCF/day & 633.0 & 770.0 & 891.0 & 720.0 \\
Oil & $10^{6}$ liters & 2914.0 & 6328.9 & 3651.4 & 2378.8 \\
Lignite & $10^{6}$ tons & 12.3 & 15.4 & 19.2 & 33.4 \\
Imported Coal & $10^{6}$ tons & 0 & 0 & 13.5 & 24.1 \\
Nuclear & tons & 0 & 0 & 0 & 26.6 \\
\hline \hline \\
Note:
\end{tabular}


To help meet demand, EGAT recently announced plans to begin purchasing power generated from renewable resources and residual fuels from small-scale private producers ( $<50 \mathrm{MW}$ ). In the spring of 1992 , EGAT reportedly began developing tender agreements with various facilities. ${ }^{13}$ The utility hopes these sources will account for 3-5\% of installed capacity in the long term. However, EGAT has incorporated these new supplies into the current power plan only as additional reserve, due to various uncertainties surrounding the successful implementation of these projects.

EGAT's longer term plans include far greater reliance on nuclear sources for electricity generation. EGAT recently asked the government to approve plans to construct six additional $1000-\mathrm{MW}$ nuclear units during the next 13 years. The utility hopes to have the six plants operational by $2006-2008 .^{14}$

\subsection{Financial Issues}

EGAT has earned a reputation as a strong institution, with a successful history of financing its own expansion. However, the growing requirements associated with future power development may pose a new challenge to the utility.

EGAT's most recent expansion plans entail a considerably higher level of investment over the next decade and a half than previous projections suggested. The development plan issued in 1987 estimated that the utility would require Baht 170 billion (US $\$ 6.8$ billion) ${ }^{15}$ between 1992 and 1997. According to the latest plan, EGAT's capital expenditures will reach a total of Baht 250 billion (US\$ 10 billion) during the 1992-96 period, with a foreign exchange requirement of Baht: 130 billion (US\$ 5.2 billion). Estimates of total capital expenditure requirements for the 1997-2001 period amount to Baht 637 billion (US\$25.5 billion), over half of which would be foreign exchange.

The current projections represent substantially higher levels of investment than have been required in the past. Actual capital expenditures during the 1987-91 period averaged about Baht 17 billion (US\$ 680 million) per year, whereas the projections for 1992-96 come to an annual average of about Baht 50 billion (US\$ 2 billion).

The financing of Thailand's future power facilities has emerged as an area of serious contention between EGAT and the Thai government. With an enormous number of planned facilities on the drawing board, government planners have become increasingly wary of EGAT's ability to self-finance future ventures. Much to EGAT's chagrin, the government recently sought to fully privatize the nation's new power facilities as a means for attracting new sources

\footnotetext{
13 "EGAT Invites Tenders for Power Sales," Bangkok Post Weekly, May 15, 1992, p.15.

16 "Thailand Plans Six Nuclear Plants," Asion Eitergy News, Vol. 2, No. 9, September 1992, p.7.

is All estimates in USS assume that 25 Baht = USS 1.
} 
of capital and avoiding the onus of accumulated debt. After a two-year battle, EGAT managed to stave off the Thai government's efforts in 1991 by agreeing to partial privatization.

The compromise agreement allows EGAT to diminish dependence on foreign loans, without sacrificing control over the nation's power supply. Under the new approach, EGAT will finance the construction of all new plants. Upon their completion, however, certain new facilities will be placed under the purview of EGAT-sponsored subsidiaries and, eventually, shares in the plants will be sold on the Thai Stock Exchange. The subsidiaries will operate the plants and sell electricity to EGAT on a contractual basis. As of September 1992, three planned facilities (two combined-cycle and one coal-fired plant) had been identified for privatization. ${ }^{16}$

\subsection{Environmental Considerations}

Based on the government's mandate, all major power projects must pass through an approval process and be evaluated for their ecological and socio-economic impacts. The utility carries out Environmental Impact Assessments (EIA) of hydro projects with storage volumes greater than 100 million cubic meters and/or with storage surface areas that extend beyond 15 square kilometers, of all pumped-storage hydro projects and of thermal power plants with more than $10 \mathrm{MW}$ of capacity. The assessments of thermal projects focus specifically on air and water quality. EIA's are only conducted for high-voltage transmission line projects when the lines are to pass through environmentally sensitive regions. When designated by the EIA findings, planned projects are modified to minimize their negative environmental impacts. According to EGAT policy, projects are continually subject to environmental monitoring throughout their development and use.

Environmental issues have begun to exert a major influence on power development in Thailand. During the 1980s the proposed construction of the Nam Choan Dam (a 580-MW project) spurred angry local protests, opposition within the government and international criticism. In 1988, after six years of public debate, a special committee from the Thai government recommended that the Nam Choan Dam be scrapped due to the uncertainty over the environmental impacts of the project. EGAT then decided to build a coal facility instead. Three years later, the World Bank delayed providing a US\$ 22 million dollar loan for the construction of the Pak Moon hydropower project in northeastern Thailand due to objections that the project would cause ecological damage and would displace large populations living in the area to be flooded. ${ }^{17}$ This history does not bode well for future hydro development in Thailand.

EGAT's Power Development Plan for a ses a significant shift in the power base towards imported coal over the next decade and a half -- in part cue to the strong oppositior: to further hydro development. However, public concern over the environmental impacts of coal plants also has increased. Recently, the construction of one unit of Ao Phai, a planned oil-/imported coal-

\footnotetext{
16 "Private Power: Worldwide Development," Independent Energy, September 1992.

${ }^{17}$ Handley, Paul (1991b), "Power Struggies," Far Eastem Econvmic Review, October 17, 1991, pp.98-99.
} 
fired unit to be built by 1997 , was postponed for two years due to uncertainties regarding the environmental impacts of the proposed facility. ${ }^{18}$ In addition, EGAT has had to respond to complaints about existing coal facilities. In early October 1992, an air-filtering device at one of the 11 lignite-burning units at the Mae Moh site broke down. The toxic emissions released from the site have been held accountable for Thailand's first case of acid rain, crop damage and over 600 cases of respiration illness. ${ }^{19}$ A broad study of the area found that 42,000 residents in the vicinity of the site have suffered health problems associated with the inhalation of lignite dust and chemicals. ${ }^{20}$ As a result of the recent incident at Mae Moh, EGAT has agreed to spend 10 billion baht (US $\$ 400$ million) installing emissions controls on four of the Mae Moh units over the next three years. ${ }^{21}$ (In the past, EGAT has using these devices due for financial reasons.) EGAT also plans to install flue gas sulphurization equipment at the proposed Ao Phai units and possibly to construct a fluidized bed combustion lignite plant at some time in the future.

In addition to contributing to local pollution, the increased reliance on coal would also translate into a substantial increase in emissions of carbon dioxide. A recent estimate projects that, based on current plans, $\mathrm{CO}_{2}$ emissions from the Thai power sector will increase from 38 million tonnes per year at present to 91 million tonnes per year in $2002 .^{22}$

Thailand's efforts to build a base of nuclear-generating capacity also may confront barriers. As the construction of Thailand's nuclear facilities draws nearer, problems such as nuclear safety and radioactive waste disposal are likely to raise public concern in Thailand. In August 1992, Thailand's National Economic and Social Development Board held a meeting attended by Thai academicians, politicians and scientists to ponder EGAT's most recent plans to develop nuclear power in Thailand. Aside from the importance of economic and safety issues, the participants of the conference identified public approval as a key factor in determining the role of nuclear in Thailand's future. ${ }^{23}$

\subsection{Electricity Supply and End-Use Efficiency}

Thermal plants in Thailand rate among the most efficient in developing Asia. In 1990, thermal efficiency averaged $37 \%$ as a share of fuel input.

\footnotetext{
$1 "$ International Institute for Energy Conservation, Asia Regional Office, Thailand: Promotion of Electricity Energy Efficiency, Pre-Invesiment Appraisal, Draft Repor, November 1992.

19 "Environmental Crisis at Mae Moh Lignite Power to Lift Generating Cost," Asian Energy' News, Vol.2. No.10, October 1992, p.6.

${ }^{20}$ IIEC, op cit., Ref. 18.

${ }^{21}$ Asian Energy News, op cit., Ref. 19.

2 Ibid.

23 Kositchotethana, Boonsong, "Call for a Consensus on Nuclear Power Plant, " Bangkok Post Weekly, August 17, 1992.
} 
Transmissiou and distribution losses for EGAT and the two major distributors, MEA and PEA, averaged $14.1 \%$ in 1990 . However, Thailand's State Planning Chief recently argued that the utility should set its goals in line with the more efficient performance of utilities in industrialized countries. ${ }^{24}$ EGAT's transmission losses are 50\% higher than in Germany, Korea and the United States. The load forecast for 2006 places total losses at $13.5 \%$, only slightly lower than the current level.

The dramatic and largely unexpected surge in electricity demand in Thailand during the latter half of the 1980s, coupled with the depletion of the nation's indigenous resource base, have spawned a growing interest in the possibilities of slowing the growth of electricity demand. As a result, time-of-day pricing -- aimed at discouraging peak-time electricity consumption -was put into effect.

More recently, the government initiated an ambitious program aimed at integrating demand-side management (DSM) into the Thai power sector. In October 1990, Thailand's National Energy Policy Committee (NEPC) directed EGAT to develop a "master plan" for promoting electricity end-use efficiency. Based on analyses conducted by the Thai National Energy Administration, the International Institute for Energy Conservation (IIEC) and Canadian consultants, IIEC assisted EGAT in preparing a comprehensive DSM plan during $1991 .{ }^{25}$ The DSM plan outlined a strategy for reducing peak demand by $225 \mathrm{MW}$ (and consumption by 1,080 GWh) by 1997 . The estimated demand savings is $1.7 \%$ of projected peak demand. The cost of the effort was estimated at US\$ 183 million.

Approval of the initial plan by the Thai government in November 1991 and support from the World Bank/Global Environmental Facility (GEF) led to an in-depth pre-investment feasibility study in 1992. The study makes numerous recommendations for DSM programs in all sectors and outlines institutional and training requirements. ${ }^{26}$ The estimated peak demand savings from programs in each sector are shown in Table 7-5, along with the estimated societal benefit-to-cost ratios of each program. The costs of the DSM resources calculated by the GEF consultants are not appreciably different from those in the original DSM Master Plan. The average long-term cost of savings from the DSM program measures is estimated at US\$0.018/kWh, well below EGAT's long-term cost of US $\$ 0.043 / \mathrm{kWh}$ to provide new electricity supply. The benefit-to-cost ratio is especially high for programs aimed at promoting more efficient refrigerators and air conditioners.

The DSM program will be largely funded by the Thai utilities. The World Bank proposes to provide approximately US\$ 40 million (through a grant and a long-term low-interest loan) in support of the program. EGAT and the other utilities will be allowed to recover DSM

\footnotetext{
${ }^{24}$ Handley, Paul, op cit., Ref. 3.

${ }^{25}$ International Institute for Energy Conservation (IIEC), Demand Side Management for Thailand 's Electric Power System, Five-Year Master Plan, November 1991.

${ }^{2}$ Iniernationai Lnstiwite for Eñergy Conservation (HEC), Thailand: Promotion of Electricity' Energy' Effciency, Final Report, February 1993.
} 
program costs in their rates. EGAT has established a DSM department, which has been charged with taking the lead in developing, implementing, marketing and evaluating the DSM programs. The two major goals for the program are to establish effective pilot programs and to develop EGAT's capacity for expanding these efforts on a larger scale.

In addition to approving the DSM plan, the Thai government enacted an Energy Conservation Promotion Act in 1992. The Act will increase the commitment and resources necessary to implement a comprehensive energy-efficiency program for all fuels and sectors. An important element is the establishment of the Energy Conservation Promotion Fund, which will provide financing to energy conservation (and renewable energy) projects.

Table 7-5. Thailand's DSM Programs

\begin{tabular}{|c|c|c|c|c|}
\hline Program & $\begin{array}{l}\text { Total resource cost", } \\
\text { benefit-to-cost ratio }\end{array}$ & $\begin{array}{l}\text { Peak savings } \\
(M W p)\end{array}$ & $\begin{array}{l}\text { Energy saved } \\
\text { (GWh/year) }\end{array}$ & $\begin{array}{l}\text { Cost of saved } \\
\text { energy } \\
\text { (cents/kWh) }\end{array}$ \\
\hline Lighting program & 2.0 & 133 & 677 & 2.2 \\
\hline \multicolumn{5}{|l|}{ Residential sector } \\
\hline Refrigerators & 6.9 & 28 & 186 & 0.4 \\
\hline Air conditioners & 9.9 & 23 & 117 & 0.3 \\
\hline \multicolumn{5}{|c|}{ Commercial/government sector } \\
\hline New buildings ${ }^{b}$ & 2.6 & 15 & 180 & 0.8 \\
\hline \multicolumn{5}{|l|}{ Industrial sector } \\
\hline Motor systems & 3.7 & 30 & 225 & 1.1 \\
\hline
\end{tabular}

Notes: a. Total resource costs include: utility DSM program administrative costs; DSM program financial incentives; and customer costs or measure costs not covered by financial incentives.

b. EGAT estimate combining new commercial building design program with Peak SHAVING. Whole program budget includes laboratory and testing, consulting, training, program administration and public relations.

Source: International Institute for Energy Conservation, Asia Regional Office, Thailand: Promotion of Electricity Energy Efficiency, Pre-Investment Appraisal, Draft Report, November 1992.

\subsection{Conclusions}

Growing financial burdens as well as recent opposition to hydro and coal-fired power plants underscore the importance of demand-side management and other conservation measures in the future of the Thai power sector. While electricity growth rates are projected to wane over the next 15 years, substantial increases in total electricity demand are expected nonetheless. Thailand's current plans place a particular emphasis on the development of coal-fired utilities in the near term and on the development of nuclear plants in the longer term. Both coal-fired and nuclear facilities are likely to face opposition, due to environmental and cost concerns.

Thailand is presently a test site for demand-side management in the developing world. No other utility in developing Asia has embarked on a comprehensive demand-side management 
strategy. If successful, EGAT's entry into this realm could present a model for neighboring nations. However, this effort only recently has been initiated. The effectiveness and staying power of demand-side management in Thailand has yet to be proven. 


\section{PHILIPPINES}

\subsection{Introduction}

The Philippine power sector has been in a state of crisis for several years. Power outages of several hours duration have been an almost daily occurrence in Manila, the rest of Luzon Island and in the southern island of Mindanao. Apart from causing discomfort, the economic costs are high. According to a World Bank study, the economy was estimated to lose some $\$ 600$ million in revenue in 1992 due to continuing power outages. ${ }^{1}$ The reasons for the power shortage are several: aging power plants that have not been well-maintained and are subject to frequent breakdown, a lack of investment in new base-load capacity, the mothballing of the controversial Bataan nuclear power plant by the Aquino government and low rainfall that has reduced hydroelectric production.

The state-owned National Power Corporation (Napocor) which controls the generation and transmission of electricity also has contributed to the problem. Its accumulation of debts and reputation for poor management have reduced its credit-worthiness with multilateral lending institutions. In fact, the World Bank stopped lending to Napocor in early 1993. While external problems have mounted, internal political resistance to raising electricity prices has further worsened Napocor's financial situation. ${ }^{2}$ In addition, the government's own need to service a large external debt burden has contributed to the inability to finance new power plants in a timely fashion.

In the wake of the $1979-80$ oil price shock, Napocor began to diversify its generating mix, which has relied mainly on imported oil. Geothermal plants were brought on line beginning in 1979, and the first large coal-fired plant was commissioned in 1984 . In the 1987-90 period, however, there was very little growth in Napocor's installed capacity. When hydro output fell in 1990 and aging thermal plants suffered outages, the system was unable to meet peak demand much of the time. Napocor added some $500 \mathrm{MW}$ of gas turbines in 1991 (including a private power project), but hydro output fell further and the shortages worsened.

Despite the growing role of geothermal energy and coal, the Philippines is still dependent on oil-fired thermal generation (Table 8-1). Napocor's installed capacity at the end of 1991 was $6543 \mathrm{MW}$, of which nearly half was fired by fuel or diesel oil.

Around three-fourth's of Napocor's total electricity generation in 1991 was in Luzon (Table 8-2). Mindanao accounted for $14 \%$ and the Visayas region for $9 \%$. Generation in Luzon

1 "45 local and foreign companies vying for BOT power projects," Asian Energy News, October i 992.

${ }^{2}$ Napocor sells about three fourths of its output to the Manila Electric Company (Meralco), and also sells to smaller distribution utilities and to a number of large industrial customers. Meralco is the sole distributor to nearly 2 million customers in Manila and neighboring provinces, a region that has $22 \%$ of the national population, produces $43 \%$ of GNP, an? nnsumes $52 \%$ of the electricity nationwide. 
is spread among the various plant types. The Mindanao grid relies mainly on hydro, while the Visayas received over half of its electricity from geothermal. Oil/diesel plants had an average capacity utilization of only $36 \%$ in 1991, which reflects the importance of diesel and peakingtype generation, as well as the poor condition of baseload fuel oil plants. The data on installed capacity somewhat overstate the role played by hydro plants, whose capacity factor of only $28 \%$ in 1991 illustrates the effect of the drought. By contrast, geothermal plants operated at $74 \%$ capacity utilization.

Table 8-1. Philippine Power Sector Statistics"

\begin{tabular}{|c|c|c|}
\hline & 1991 & AAGR $(1981-91)^{b}$ \\
\hline Installed Capacity (MW) & $6543(100 \%)$ & 4.4 \\
\hline Hydro & $2138(32.6 \%)$ & 8.2 \\
\hline Oil & $3112(47.6 \%)$ & 1.3 \\
\hline Coal & $405(6.2 \%)$ & 20.9 \\
\hline Geothermal & $888(13.5 \%)$ & 5.7 \\
\hline Generation (GWh) & $25654(100 \%)$ & 4.5 \\
\hline Hydro & $5145(20.0 \%)$ & 3.2 \\
\hline Thermal & $14752(57.5 \%)$ & 4.1 \\
\hline Coal-fired & $1942(7.6 \%)$ & $38.6^{\mathrm{c}}$ \\
\hline Oil-fired & $12810(49.9 \%)$ & 2.7 \\
\hline Geothermal & $5757(22.4 \%)$ & 7.3 \\
\hline Consumption (GWh) & $20436(100 \%)$ & 4.1 \\
\hline Industrial & $9339(45.7 \%)$ & 4.4 \\
\hline Residential & $6249(30.6 \%)$ & 4.5 \\
\hline Commercial & $4848(23.7 \%)$ & 3.0 \\
\hline
\end{tabular}

Notes: - Figures do not include self-producers.

- AAGR = Average Annual Growth Rate

c Coal fired generation began in 1982.

Table 8-2. Philippines: Electricity Generation by Source \& Region, 1991 (GWh)

\begin{tabular}{lrrrrrrr}
\hline & Hydro & Diesel & Geothermal & Oil & Coal & Gas & Total \\
\hline \hline Luzon & 1858 & - & 4490 & 9798 & 1827 & 1522 & 19495 \\
Visayas & 10 & 480 & 1269 & 112 & 116 & 292 & 2279 \\
Mindanao & 3230 & 208 & - & - & - & 209 & 3647 \\
Philippines & 5098 & 688 & 5759 & 9910 & 1943 & 2023 & 25421 \\
\hline \hline
\end{tabular}

Source: Napocor, Power System Performance Report, 1992 


\subsection{Resources for Electricity Generation}

Relative to its neighbors in Southeast Asia, the Philippines is not well-endowed with indigenous energy resources that can be economically developed. Proven oil reserves amount to only 4 million tons (Mt), and production has been declining since 1983. The discovery of a new reservoir in the Palawan oil fields (est.15.6 Mt) could substantially boost the country's reserves, but nearly all of the oil is geared towards export since Philippine refineries do not have the capacity to process such a light crude. ${ }^{3}$ Recently, there was a major discovery of natural gas north of Manila Bay.

Geothermal reserves are considerable and are found throughout the country. Potential reserves were estimated at $8 \mathrm{GW}$ in 1988, of which $1.6 \mathrm{GW}$ are proven so far and $4.4 \mathrm{GW}$ are considered probable. Currently, the country's 439 wells supply $888 \mathrm{MW}$ of generation capacity, which is $63 \%$ of the capacity of the developed fields.

The potential coal resource is estimated at about 1500 million tons (with proved reserves of 300 million tons), but most of it is low-grade and expensive to mine. Annual production is currently 1.4 MT. Imported coal will be increasingly relied upon to supplement domestic production in the future.

Hydro resources have a theoretical potential in excess of $10 \mathrm{GW}$, but the better sites are distant from the grid and expensive to exploit. Hydro development in Mindanao is also constrained by socio-political considerations. As for non-conventional renewables, there are considerable amounts of agricultural residues that could be used for electricity generation.

\subsection{Forecast of Electricity Demand}

Given the severe electricity shortage in the Philippines, forecasts of demand are not very relevant over the next few years. Electricity users will absorb whatever the system is able to deliver. However, a forecast of future demand is indicative of the load that a healthy power system might need to meet.

In making its electricity demand forecast for the Philippine Energy Plan 1991-2000, the government predicted that GDP growth will average $6.2 \%$ /year over the decade. A $7.7 \%$ annual increase in load requirements was estimated, implying a total peak demand of some $8.1 \mathrm{GW}$ by 2000. Projected demand growth is highest through 1995 in the Visayas region (10.7\%/year), while Luzon is expected to experience the highest demand growth rate $(8.2 \%$ /year) for the latter half of the decade. Partly due to drought and load curtailment for Mindanao, the actual load growth rate for the country in 1991 was $2.7 \%$.

3 "Palawan oil find could bolster Philippine economy, barrels of hope," Far Eastern Economic Review, February 6, 1992. 
Rural electric service is expected to grow so that by the year $200077 \%$ of rural households (or 4.7 million out of 6.1 million rural households) are expected to have electricity. Currently, $56 \%$ of rural households are hooked up to the grid. In 1992, total electrification of all municipalities (though not all households) in the franchise area of the rural electric cooperatives was to be completed. The rural electrification program has been politically committed, but is for all practical purposes non-viable due to the existing power crisis.

Table 8-3. Philippine Electricity Demand Forecast

\begin{tabular}{lccc}
\hline \hline Region & AAGR & AAGR & Peak Demand \\
\hline \hline Visayas & 10.7 & 6.5 & 812 \\
Mindanao & 7.9 & 6.5 & 1243 \\
Luzon & 7.1 & 8.2 & 6038 \\
Philippines & - & - & 8093 \\
\hline \hline
\end{tabular}

Source: Office of Energy Affairs, Philippine Energy Plan, 1991-2000, Manila, 1992.

\subsection{Plans for Power Sector Development}

The Office of Energy Affairs (OEA), successor to the Ministry of Energy, had been in charge of the planning and coordination of power programs. There is now a new Department of Energy at the cabinet level, widely seen as a major step forward toward resolving political gridlock on power projects. Rural electrification falls under the National Electrification Administration (NEA).

The power development program outlined in the Philippine Energy Plan 1991-2000 indicates that the system will rely largely on imported coal and geothermal energy for new capacity. The Plan calls for the installation of about 5,100 MW of new capacity in 1992-2000, thereby increasing the country's overall capacity from roughly $6,800 \mathrm{MW}$ to nearly $12,000 \mathrm{MW}$ (Figure 8-1). ${ }^{4}$ This assumes that no retirements of existing plants will take place. Additions of coal-fired plants (2500 MW) and geothermal (1600 MW) account for the bulk of the new capacity development. Installed hydro capacity is projected to increase by $353 \mathrm{MW}$ to a total of 2,509 MW. Based on past experience and the current difficulties faced by Napocor, it would be very surprising if the targets in the Plan were met. The geothermal target is quite optimistic, given the problems at some of the prospective sites, and most of the planned new hydro capacity is unlikely to be built by the year 2000 .

Because of the difficulties in raising capital, the actual increase in capacity and the evolution of the generating mix will depend to a large degree on the success of the government's efforts to attract private power projects. The favored approach is to utilize Build-OperateTransfer (BOT) schemes in which a private investor builds and operates a power plant for a

\footnotetext{
4 This figure includes a small amount of non-NPC capacity.
} 


\section{Philippine Power Development Plans Installed Capacity}

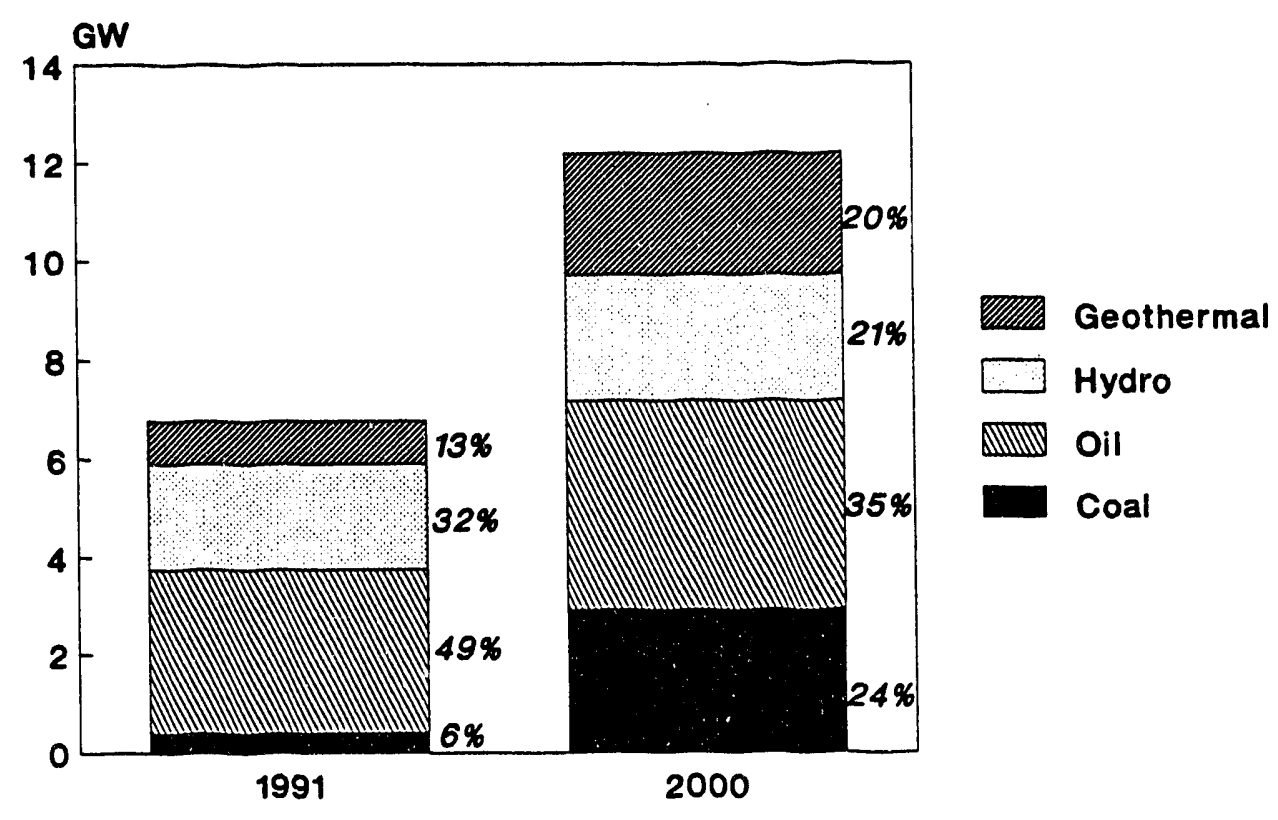

Figure 8-1 
specified period, selling power to the utility for distribution, after which ownership of the facility is transferred to the government. ${ }^{5}$ As of the end of 1991, four power projects covering 1222 MW were confirmed for definite implementation; another $520 \mathrm{MW}$ is hoped for by $1995 .^{6}$ The largest single project is the 700-MW coal-fired plant for Luzon to be built by a Hong Kong-based company (Hopewell), which commissioned a 210-MW gas turbine as a BOT project near Manila in 1991.

Table 8-4. Philippine Power Development Program

\begin{tabular}{lccc}
\hline & \multicolumn{3}{c}{ Installed Capacity } \\
\cline { 2 - 4 } Plant Type & 1991 & Additions & 2000 \\
\hline Hydro & $2155(32 \%)$ & 353 & $2509(21 \%)$ \\
Oil & $3341(49 \%)$ & $618^{\mathrm{b}}$ & $4289(36 \%)$ \\
Coal & $405(6 \%)$ & 2500 & $2905(24 \%)$ \\
Geothermal & $888(13 \%)$ & 1595 & $2483(20 \%)$ \\
Total & $6789(100 \%)$ & 5066 & $11855(100 \%)$ \\
\hline \hline & Notes: & Includes rural electric cooperatives (93 MW in 1991) and private utilities (159 MW). \\
Source: & Office of Energy Affairs, Philippine Energy Plan, 1991-2000, Manila, 1992.
\end{tabular}

To alleviate electricity shortages, the government has placed four private power projects for the Luzon grid (totalling $715 \mathrm{MW}$ ) on a fast track. As of September 1992, however, only one of the projects (a 100-MW gas turbine plant) was on schedule. ${ }^{7}$ The government is also allowing Meralco, which had its own generating plants before they were transferred to Napocor by the Marcos government in the 1970s, to make private arrangements for electricity supply. In late 1991 , the company signed an agreement to buy power from a 300-MW coal-fired plant to be built by a group of private Filipino investors. ${ }^{8}$ Meralco has also agreed to purchase power from a 330-MW LNG-fired power plant, which is the first base-load LNG power plant approved by the government under the BOT arrangements. ${ }^{9}$ As a short-term measure, Meralco and Napocor have offered financial incentives for electricity-intensive industries to run their own

\footnotetext{
s The BOT approach in the Philippines is relatively recent. In 1990 a law was quickly rushed through that allowed power plants to be built via BOT mechanisms. ("Powerful solutions: Philippine project shows benefits to build-operate-transfer schemes," Far Eastern Economic Review, July 9, 1992.)

${ }^{6}$ Office of Energy Affairs, memorandum, February 1992. The confirmed projects are: $300 \mathrm{MW}$ Bataan combined cycle plant, $12 \mathrm{MW}$ Makban binary geothermal plant, $210 \mathrm{MW}$ Mindanao power project, and $350 \mathrm{MW}$ of the $700 \mathrm{MW}$ Hopewell coalthermal plant.

7 "Fast-track power projects delayed," Asian Energy News, September 1992.

8 "Analysts are predicting blue-chip status for Meralco, but some have reservations," Asian Wall Street Journal, January, 6, 1992.

${ }^{9}$ Asian Energy News, November 1992.
} 
diesel generators. The Bureau of Internal Revenue also allowed for the acceleration of the depreciation costs of power generators to reinforce the same policy. ${ }^{10}$

Although not mentioned explicitly in the Plan, the 660-MW Bataan nuclear reactor may become operational. Originally planned to be started in 1986, the Westinghouse designed plant was opposed for safety reasons and the Aquino administration mothballed the project. As a result of a suit by the Philippine government against Westinghouse for poor construction and allegations of kickbacks to the Marcos administration, the American company has agreed to pay for the needed plant rehabilitation in exchange for the suit being dropped. ${ }^{11}$ It has been recognized that the Aquino government's failure to implement an alternative power program after canceling Bataan was a major contributing factor to the current electricity shortages.

\subsection{Financial and Institutional Issues}

Power development and rural electrification account for $85 \%$ of the total financial requirements in the Philippine Energy Plan, or P338 billion ( $\$ 12.7$ billion). According to one estimate, the installation of an additional 3,700 MW of generation capacity by the year 2000 would require $\$ 7.5$ billion in investment. ${ }^{12}$

The precarious financial condition of Napocor, combined with the government's heavy debt burden, severely constrain the options for power sector expansion, particularly since the planned power projects have a large foreign exchange component. Napocor lacks capital resources of its own, and its poor performance has caused multilateral institutions to limit their lending. A key concern of these institutions is electricity tariffs that do not reflect marginal costs. ${ }^{13}$ Under pressure from the IMF, the government raised tariffs at the end of 1991 . These price hikes recently back-fired, however, when the World Bank decided to suspend its financing program due to a decision by the Philippine Supreme Court declaring that the utility's new higher rates had been unconstitutionally implemented. Rates were nonetheless due to further increase in late December 1992, but the increase was rescinded be the government. While increased revenues will help, better management is needed for Napocor to expand and properly maintain its system. Many people believe "corporatization" or privatization of Napocor (along the lines of the National Petroleum Corporation) is a necessary step. Napocor salaries and civil service constraints limit its ability to retain competent engineering and planning staff, as well as its ability to fire incompetent staff. Major institutional change therefore will be required to improve management and accountability.

\footnotetext{
10 "Power companies offer incentives for self-generation," Asian Energy News, September 1992.

"Estimates on the rehabilitation and upgrading of the nuclear plant run up to $\$ 400$ million. ("Power failures epitomize nation's economic failures," Asian Wall Street Journal, May 11, 1992.)

12 Ibid.

${ }^{13}$ Electricity tariffs are set by the Energy Regulatcry Board (ERB), a nominally independent government entity. The unpopularity of electricity rate increases has led the ERB to set tarifís below the marginal cost of generation.
} 
The weight placed on private power presents institutional challenges as well. While the government expresses a commitment to offering reasonable terms to private investors, their interest in power projects is tempered by uncertainty about electricity prices. Prospective investors want the government to guarantee a minimum rate of return on projects as a hedge against political manipulation of prices. At the same time, there is some concern that the private power projects, which often rely on multilateral lending institutions for loans or co-financing, may reduce the pool of concessional loans available to the government. Private investment has been less than hoped, and estimates are that shortages will continue at least through 1995 at the current investment rate. ${ }^{14}$

\subsection{Environmental Considerations}

Environmental opposition prevented approvals of all new facilities from 1986 through 1990 or 1991. In part, this backlash was blamed on the lack of cabinet level negotiations as only the Environmental Ministry had such representation, without similar representation for the electric power system through a cabinet level energy department. Another factor has been NPC's unwillingness to mold projects to meet environmental concerns or to conduct public education efforts to demonstrate the need.

Opposition to new coal-fired plants and geothermal energy projects has become a factor in the Philippines. Some of Napocor's major projects, such as the Masinloc and Calaca II coalfired plants, and the Mt. Apo geothermal plant, have been stalled due to large-scale sociocultural and environmental protests. In early 1992, the government decided to fast-track environmental clearances for at least three of these controversial projects, but this engendered more criticism. ${ }^{15}$ In October 1992, the Philippine Environmental Action Network, an organization which has been spearheading protests against new power projects, called for mass action against three proposed power plants in provinces near Manila, including Napocor's second coal-fired unit at Calaca. ${ }^{16}$ Such protests may delay construction of these projects, but some high priority projects are still being cleared for construction. In late November 1992, the government issued environmental clearance for a 700-MW coal-fired plant in Pagpilao with the understanding that the developer, Hopewell, will institute an environmental program during plant operation. ${ }^{17}$

On Mindanao, tribal peoples, church groups, conservationists and leftist guerrillas have joined forces to oppose a geothermal power plant being constructed in a rainforest located in a

\footnotetext{
${ }^{14}$ Asian Wall Street Journal, op cit., Ref. 10. (Comments by the Director General of the National Economic Development Authority).

is "The Philippines: In Search of Sustainable Energy Options," SEA News, September-December 1992.

16 "More heat than light: fower shortage poses big test for Ramos," Far Eastern Economic Review, December 3, 1992.

17 "Pagpilao get environmental clearance," Asian Energy News, November 1992.
} 

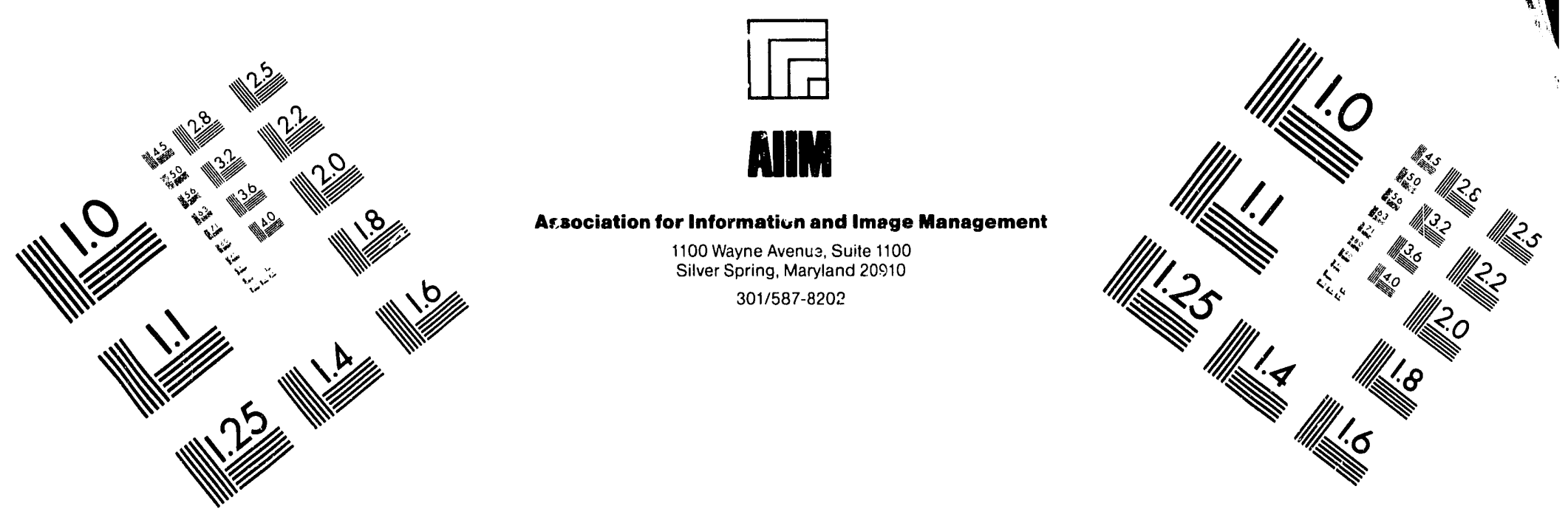

\section{Contimeter}

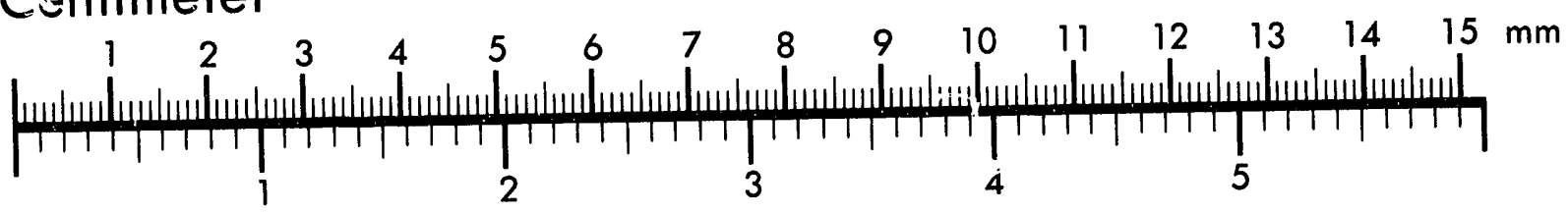
Inches
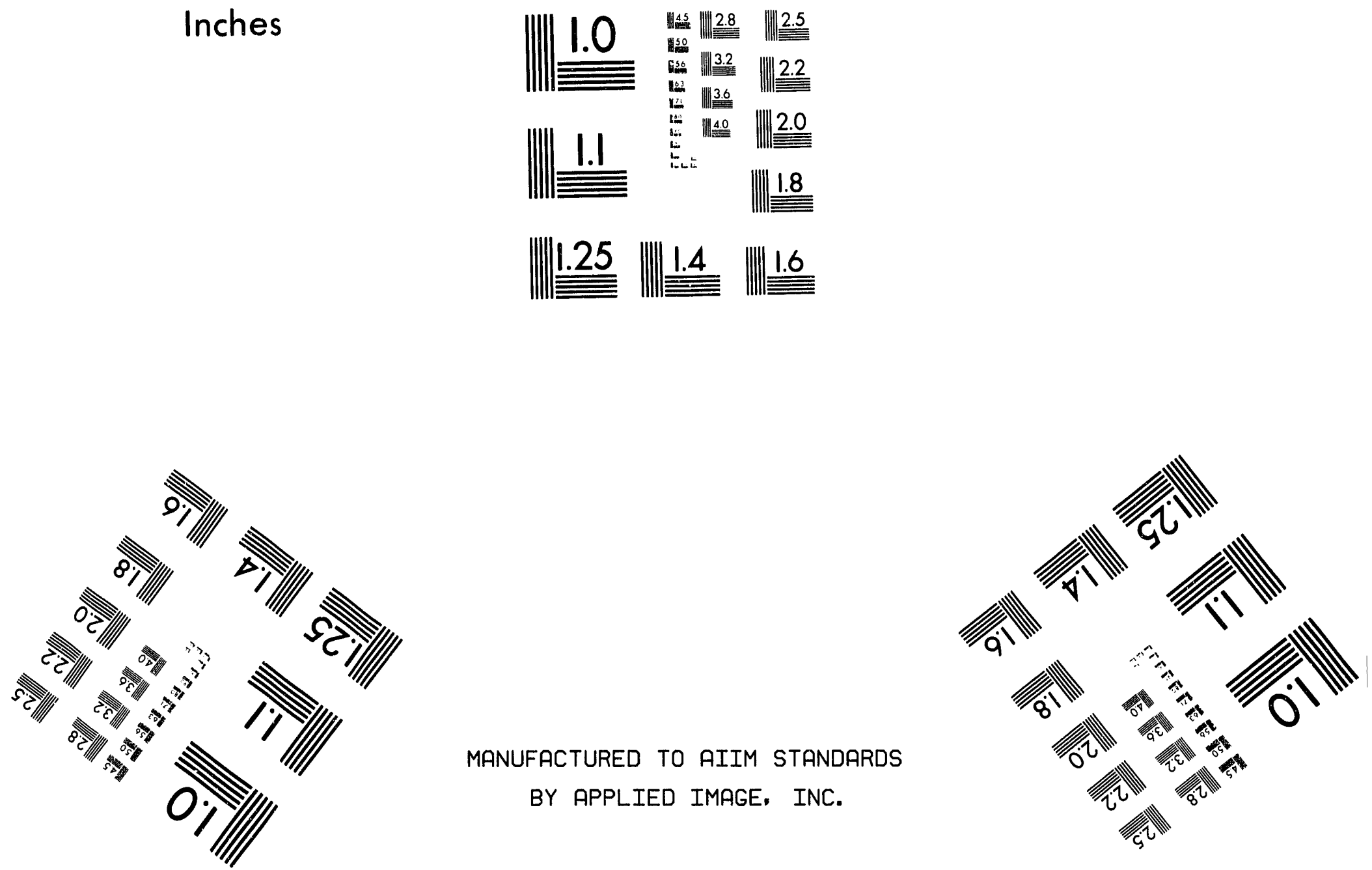

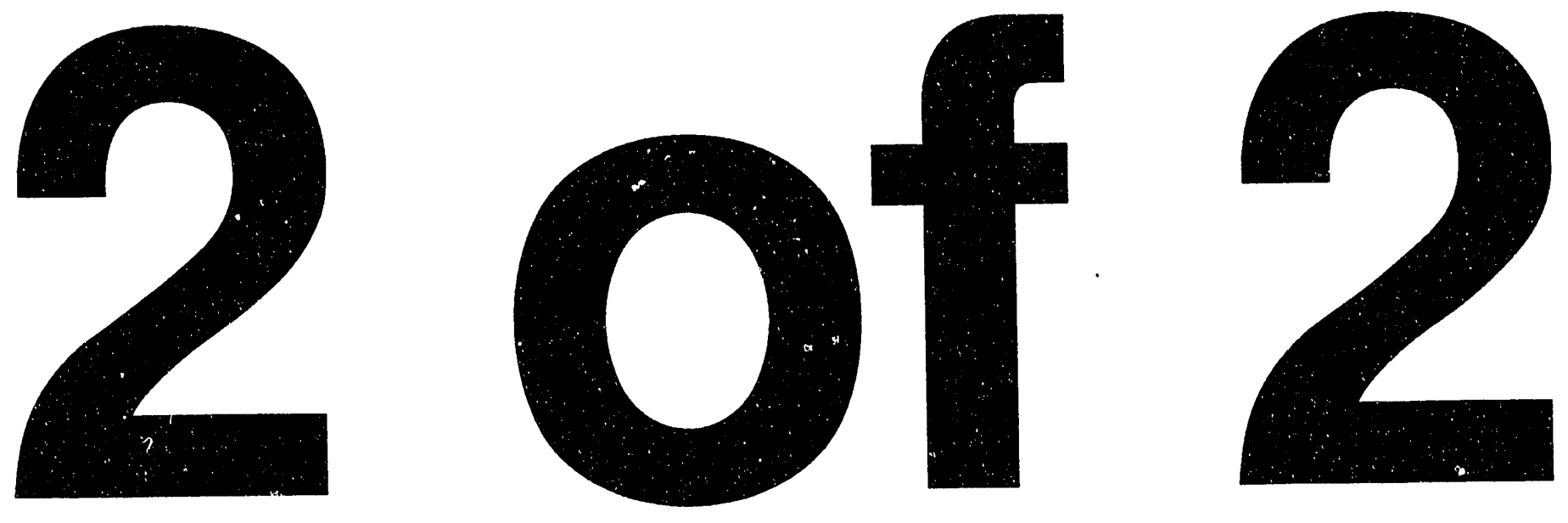
national park. Construction of the plant had been delayed for two years because of complaints from the affected communities, and then was resumed in 1992.

\subsection{Electricity Supply and End-Use Efficiency}

The government recognizes the need for stronger efforts to increase electricity supply and end-use efficiency. On the supply side, the efficiency of Napocor's oil-fired steam plants could be improved with rehabilitation and better maintenance. With time, the addition of new power stations will lessen the current heavy reliance on inefficient gas turbine and diesel plants. T\&D losses have declined in recent years (in part due to stronger efforts to curb theft), but at around $14 \%$ in 1990 they were still higher than in Thaiidnd, for example.

Plans include the introduction of time-of-day pricing and higher demand charges, which will provide an incentive to reduce or shift peak-period demand. The government says it intends to restructure power rates based on long-run marginal costs. However, implementing price hikes could prove politically difficult. Generally higher prices also provide incentives to encourage more efficient electricity use. The government plans education and information campaigns, energy audits and advisory services to energy-intensive industrial and commercial establishments, and the enactment of conservation legislation to complement long-run marginal cost pricing signals. The Philippines is the first Asian country (except for Taiwan) to establish minimum efficiency standards for refrigerators. While the initial standard is rather lenient, the government also implemented an ifficiency labeling program for refrigerators to assist consumers. Standards and labels are also under development for air conditioners.

\subsection{Conclusion}

The Philippines's power sector has been in crisis for the past several years. The new government recognizes that lack of power is a serious constraint on economic growth and is committed to alleviating the shortages that have plagued the country. However, the financial situation and institutional track record of Napocor severely limit the ability of the government to build new power plants. As a result, it is leaning heavily on private power projects. Such projects are moving forward, but settlement of terms that are agreeable to both the government and investors may slow the process as will environmental considerations. The likely outcome is that oil-based projects (gas turbines and combined-cycle plants) will play a greater role in the short term, while larger projects based on imported coal may prove viable in the long term. In either case, privately constructed and financed projects are likely to play a substantial role in new generating capacity additions. 


\section{MEXICO}

\subsection{Introduction}

The Comision Federal de Electricidad (CFE), a federally-owned company, generates and distributes almost all the electricity in Mexico. Compañía de Luz y Fuerza del Centro distributes electricity in Mexico City and surrounding metropolitan area. ${ }^{1}$ The electricity to all the country except the Baja California peninsula is in one interconnected grid. Two smaller grids serve the Baja California area.

The installed capacity of the CFE system increased from $14.6 \mathrm{GW}$ in 1980 to $26.8 \mathrm{GW}$ in 1991. Most of the growth has been in dual-fuel-capable (oil and gas) and coal-fired power plants, though about $1000 \mathrm{MW}$ of new hydroelectric capacity was added in 1987. At the end of 1991 , the plant mix included $12.5 \mathrm{GW}$ in steam power stations $1.8 \mathrm{GW}$ combined cycle, 1.8 GW gas turbines, $1.2 \mathrm{GW}$ coal-fired units, $7.9 \mathrm{GW}$ in hydro power stations, $0.72 \mathrm{GW}$ in geothermal power plants, and $0.67 \mathrm{GW}$ in the first unit of Mexico's controversial Laguna Verde nuclear power plant (Table 9-1).

Public electricity generation grew at an average annual rate of $6.3 \%$ in the $1980-1990$ period, much faster than GDP growth, which averaged only $2.1 \%$ per year in the same period. ${ }^{2}$ In early 1990, CFE envisioned a shortfall in capacity by mid-1993, but lower than expected demand growth during the past two years has resulted in a fairly comfortable reserve margin. There has been a significant shift in this historical trend since 1989, when electricity demand increased by $8.1 \%$ and GDP grew at 3.3\% (much faster than during the 1979-1988 period in which GDP only grew at an average rate of $1.7 \%$ ). In 1990, GDP and electricity grew at almost the same rate (3.9\% and $4.1 \%$ respectively). In 1991, for the first time in history, GDP growth was higher than electricity demand growth $(3.6 \%$ and $3.1 \%$ respectively). Slower growth is expected for both GDP and electricity demand in 1992 and 1993 as a consequence of a slowing down of the economy.

Except for an increase in use of coal (from the Northern region of the country), the fuel mix of electricity generation has not changed greatly since 1980 . In $1991,60 \%$ of generation was from steam plants, $7 \%$ from coal, $5 \%$ from geothermal, $18 \%$ from hydropower, and $4 \%$ from nuclear.

Industry is the main consuming sector (56\% in 1991), followed by the residential sector (23\%), the commercial sector $(9 \%)$, agricultural water pumping $(7 \%)$, and the public sector

\footnotetext{
${ }^{1}$ Compañía de Luz y Fuerza del Centro has been undergoing liquidation for over 30 years. This process has been hindered by the labor unions and a small number of foreign shareholders who were finally bought out by the Mexican government in 1992. It is not clear at this time if the company will finally be merged with CFE or will be revitalized as a separate and autonomous entity.

${ }^{2}$ This period included one of the worst recessions in Mexico's history. For comparison, the growth rate of the Mexican economy in the $1973-1980$ period was $6.5 \%$ per year, while electricity demand grew by $7.8 \%$ per year.
} 
(5\%). The residential sector led the growth in electricity demand during the 1970 s and the first part of the 1980s and 1990s; its rate of growth only diminished in the mid and late 1980s as a consequence of the economic crisis. Demand in the industrial sector has experienced the fastest rate of growth since the economic crisis of 1982 (5.9\% per year). In contrast, commercial electricity demand grew at only $1.3 \%$ per year during this period.

Table 9-1. Power Sector Statistics for Mexico (not including self-producers)

\begin{tabular}{|c|c|c|c|}
\hline & \multicolumn{2}{|c|}{1991} & \multirow{2}{*}{$\begin{array}{c}\text { AAGR } \\
1980-1990\end{array}$} \\
\hline & $(G W)$ & $(\%)$ & \\
\hline Installed Capacity & $26.8^{b}$ & 100 & $5.6 \%$ \\
\hline Hydro & 7.9 & 30 & $2.7 \%$ \\
\hline Coal-fired & 1.2 & 4 & $16.7 \%$ \\
\hline Steam" & 12.7 & 47 & $5.6 \%$ \\
\hline Gas turbine & 1.8 & 7 & $4.1 \%$ \\
\hline Combined-cycle & 1.8 & 7 & $12.1 \%$ \\
\hline Geothermal & 0.7 & 3 & $18.8 \%$ \\
\hline Nuclear & 0.7 & 2 & --- \\
\hline Generation (TWh) & $118.4^{\mathrm{b}}$ & 100 & $6.3 \%$ \\
\hline Hydro & 21.7 & 18 & $3.4 \%$ \\
\hline Coal-fired & 8.1 & 7 & $25.3 \%^{c}$ \\
\hline Steam & 70.3 & 59 & $6.1 \%$ \\
\hline Gas turbine & 0.7 & 1 & $\cdots$ \\
\hline Combined-cycle & 7.7 & 7 & $8.7 \%$ \\
\hline Geothermal & 5.4 & 5 & $18.8 \%$ \\
\hline Nuclear & 4.2 & 3 & --- \\
\hline Consumption (TWh) & 94.8 & 100 & $5.9 \%$ \\
\hline Industry & 53.0 & 56 & $6.0 \%$ \\
\hline Residential & 22.0 & 23 & $7.0 \%$ \\
\hline Commercial & 8.6 & 9 & $3.5 \%$ \\
\hline Government & 4.7 & 5 & --- \\
\hline Agriculture & 6.5 & 7 & $7.7 \%$ \\
\hline
\end{tabular}

Notes: a. Mostly oil-fired

b. Includes diesel plants

c. $1982-1990$

Source: CFE 


\subsection{Resources for Electricity Generation ${ }^{3}$}

Proved oil reserves are 50 billion barrels, with a current reserves/production ratio of 50 years. Natural gas reserves are approximately 2025 billion $\mathrm{m}^{3}$, with estimated additional recoverable reserves three times larger. Proven reserves of coal ( $98 \%$ bituminous) amount to approximately 1720 million tons.

Mexico's exploitable hydropower capability is estimated at $80,000 \mathrm{GWh} /$ year for sites with more than $2 \mathrm{MW}$. Hydro resources are distributed throughout the country, but potential for large developments is concentrated in the South of the country, a region in which the country's tropical rainforests are concentrated. Geothermal energy resources have not been carefully assessed, but probable reserves are estimated at around $5 \mathrm{GW}$.

\subsection{Forecast of Electricity Demand}

Electricity consumption has continued to grow since 1981 despite the economic stagnation. Of significance is the decrease in the historical rate of growth in electrical consumption during the past 3 years to about $3 \%$ per year. Growth is expected to remain at this level for the next couple of years.

Three scenarios for electricity sales growth between 1991 and 2001 were published by CFE in 1992. The scenarios vary from a low growth rate of $5.9 \%$ to a high of $7.7 \%$, with a medium case of $6.8 \%$ growth per annum. The scenarios are based on macroeconometric and sectoral analyses. They assume GDP growth rates of $3 \%$ to $6 \%$, a $1.5 \%$ population growth rate, and $2.4 \%$ growth rate in the number of homes. ${ }^{4}$

Given the uncertainties surrounding Mexico's debt situation, the possible privatization of the energy sector, the coming National elections, and the political fate of the government's economic policies, it is difficult to forecast growth in demand with confidence. Many local experts consider the projected growth to be high, particularly in view of the growth in electricity demand since 1990 and significant decrease in GDP growth in 1992. Despite the new debt accord reached in July 1989, the privatization of many government industries, the strong influx of capital to Mexico in the past 3 years, the government's free-market policies, and the NAFTA, there is much uncertainty whether Mexico will be able to achieve substantial real growth in the rest of the decade. 5

\footnotetext{
${ }^{3}$ Data are taken from World Energy Council, 1992 Survey of Energy Resources (Oxford: Holywell Press Ltd), 1992.

4 CFE, Programa de Obras e Inversiones del Sector Eléctrico - POISE, Preliminar, Mexico, May 1992.

5 "Mexico feels squeeze after years of austerity," The New York Times, July 27, 1989; "Renewed Resource Flows to Latin America," Development Policy, IADB, December 1992.
} 
Growth in demand will depend in part on the evolution of electricity prices. Government plans call for the elimination of electricity subsidies, but there is fear that this could have a significant inflationary effect. Given the political challenge coming from the populist movement, raising residential rates could be difficult for the government.

One potential source of considerable growth in demand is air conditioning. In the northern part of the country, the hot climate and relative economic prosperity (due partly to the proximity to the U.S.) have already combined to bring rapid growth in home air conditioning.

\subsection{Plans for Power Sector Development}

CFE's expansion of its electricity generating capacity has in the past tended to proceed at a much faster pace than growth in the economy. In part this is because growth in demand was well above the rate of increase in GDP, but it also reflects the ability of CFE, supported by the utility's union and construction companies, to gain resources from the government. In the past few years, CFE has also been able to obtain foreign investment financing for new power plants.

CFE's Programa de Obras e Inversiones del Sector Electrico (POISE), released in May 1992 , projects growth in total installed capacity from $26.8 \mathrm{GW}$ in 1991 to $42 \mathrm{GW}$ in 2000 . This increase of about $15 \mathrm{GW}$ in nine years is equivalent in magnitude to the increase that occurred between 1977 and 1991. The total addition includes $2.8 \mathrm{GW}$ of new hydro capacity, $5.5 \mathrm{GW}$ of dual-fuel (coal/oil) capacity, $1.4 \mathrm{GW}$ of coal-fired capacity, $0.3 \mathrm{GW}$ of geothermal, and 0.7 GW of nuclear (the second unit of Laguna Verde, which is scheduled to begin operation in 1995). Based on CFE's schedule, the installed capacity in the year 2000 will be $25 \%$ hydro, $6 \%$ coal-fired, $13 \%$ dual fuel (mostly coal-fired), $49 \%$ oil/gas, and about $3 \%$ each for geothermal and nuclear (Table 9-2) (Figure 9-1). The dual-fuel plants, which are designed to give CFE flexibility in case oil prices fall, are likely to use imported coal due to the insufficient quality and quantity of domestic coal.

Small geothermal (20 MW), two hydroelectric plants (66 MW and $110 \mathrm{MW})$, and coal-fired plants $(700 \mathrm{MW})$ without desulfurizing equipment are amongst the cheapest alternatives for electricity generation according to CFE's estimates. ${ }^{6}$ New hydroelectric supplies are attractive on a per $\mathrm{kWh}$ basis but are also very capital-intensive and face increasing opposition from environmental sources and populations whose land would be inundated. Given the financial situation of CFE, this may make their exploitation difficult?

\footnotetext{
${ }^{6}$ CFE, Costos y Parametros de Referencia para la Formulacion de Proyectos de Inversion en el Sector Electrico, Mexico, July 1991.

${ }^{7}$ Fernandez de la Garza, G., "Retos Tecnologicos en el Sector Energetico," Cuadernos sobre Prospectiva Energetica 115, El Colegio de Mexico, 1988.
} 


\section{Mexican Power Development Plans Installed Capacity}

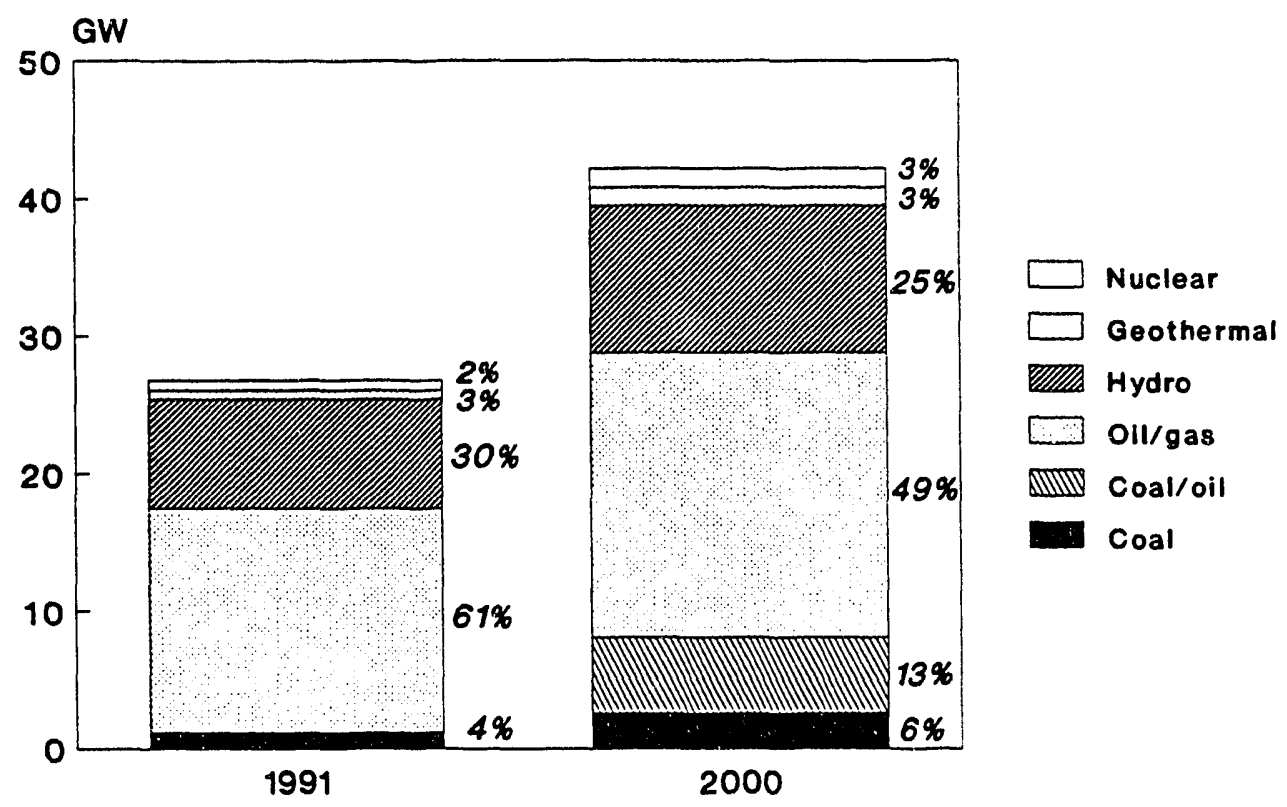

Figure 9-1 
New identified geothermal supplies are small and do not permit CFE to base much future expansion on this source. More exploration is required to fully assess the resource potential and its economic viability. Mexico's geography and numerous natural hot water spas would seem to indicate that this resource may continue to expand.

Table 9-2. Plan for Mexico Electricity Supply (Installed capacity in GW)

\begin{tabular}{lrrrrrr}
\hline \hline & 1991 & $\%$ & 1995 & $\%$ & 2000 & $\%$ \\
\hline \hline Oil/gas" & 16.3 & 61 & 17.7 & 51 & 20.7 & 49 \\
Coal & 1.2 & 4 & 2.6 & 7 & 2.6 & 6 \\
Coal/oil & 0 & 0 & 2.8 & 8 & 5.4 & 13 \\
Geothermal & 0.7 & 3 & 0.9 & 3 & 1.4 & 3 \\
Nuclear & 0.7 & 2 & 1.3 & 4 & 1.3 & 3 \\
Hydro & 7.9 & 30 & 9.4 & 27 & 10.7 & 25 \\
Total & 26.8 & 100 & 34.7 & 100 & 42.1 & 100 \\
\hline \hline
\end{tabular}

Note: a. Includes diesel, combined-cycle, gas turbines.

Source: Based on CFE, Programa de Obras e Inversiones del Sector Eléctrico -- POISE, Preliminar, Mexico, May 1992.

\subsection{Financial Issues}

The future development of Mexico's power sector is constrained by the difficult financial situation of CFE, which stems from several factors. One is the huge investment in the power sector that has taken place in the past two decades. The Laguna Verde nuclear power plant has required substantial amounts of capital, much of which was financed by foreign loans. While this took place, electricity prices were maintained by the government at a level insufficient to recover costs. In 1982 the economy entered into a period of recession and stagnation from which it began to recover in late 1989, only to stagnate again in 1992. At the same time, interest rates on foreign loans rose substantially, increasing CFE's debt. High inflation increased the cost of power projects, and CFE's operations required considerable subsidy from the government.

Increase in electricity prices in the 1982-1986 period helped the situation, but prices were frozen in 1987 as part of a "Solidarity Pact" between the government and various economic sectors. The pricing policy changed again in 1991 when CFE embarked on a plan to reduce subsidies. In real terms, electric tariffs increased only by a small amount. The residential sector remains highly subsidized (one estimate placing this subsidy at about \$US 750 million in 
1990). ${ }^{8}$ CFE's revenues in 1988 covered only $60-65 \%$ of operating costs. ${ }^{9}$ CFE hopes to construct a significant portion ( 9 out of $15.2 \mathrm{GW}$ ) of the new capacity with private financing. ${ }^{10}$

The financial condition of CFE and the difficulty of raising capital have important implications for the development of the power sector. One is the need for CFE to rationalize and improve the efficiency of its operations in order to reduce costs. The situation also strengthens the argument for power projects that have low capital costs and short construction times.

\subsection{Environmental Considerations}

Air pollution is a concern for CFE's oil-fired plants located in the outskirts of Mexico City and to a lesser degree, Monterrey. CFE has been implementing programs to reduce emissions and concentration of pollutants. Measures have included installation of $120 \mathrm{~m}$. tall chimneys and burners with low NOx emissions.

Another problem is the lack of water for power plant cooling in Mexico's northern region. Currently, water is taken from underground sources, just as drinking water is.

Hydroelectric power plants are facing increasing opposition from environmental groups and local people that would be displaced. The Laguna Verde nuclear power plant has faced strong opposition from diverse sectors. Safety standards and economic evaluations made by the CFE have been heavily criticized, as has the capacity of the government to design and put in practice credible emergency plans in case of a reactor accident. Efforts to build additional nuclear plants are likely to face considerable opposition.

Coal power plants are relatively new in Mexico. Their continued expansion will probably be possible only with the installation of scrubbers, desulfurizers, and other pollution abatement equipment. Significant infrastructure enhancements are required to handle the imported coal (port and transportation facilities), with their accompanying environmental impacts. Currenı plans call for a significant amount of the coal plants to be sited close to the Texas border. This could lead to opposition from the U.S. due to acid precipitation issues. Global warming considerations may also influence the continued expansion of coal-fired power plants.

Mexico has a considerable knowledge of geothermal power plants' fluid and gaseous effluents and their impacts on the environment. Awareness of these impacts is growing among the Mexican environmental groups.

\footnotetext{
8 Friedmann, R., "El Sector Electrico Residencial Mexicano: Principales Usos Finales Y Potencial De Ahorro," XII Seminario Nacional Sobre el Uso Racional de la Energía, ATPAE, Mexico DF, November 1991.

9 "La Comision Federal de Electricidad mantendra el subsidio a las tarifas", La Jornada, Mexico, August 1989.

${ }^{10}$ CFE, op cit., Ref. 4.
} 


\subsection{Electricity Supply and End-Use Efficiency}

Although in recent years there has been some increase in the thermal efficiency of steam power plants, the efficiency of Mexico's power plants is still low $(32.8 \%)$ by international standards. CFE has also undertaken projects to reduce transmission, distribution, and nontechnical loses.

The increase in elcctricity prices during 1983-86 and again since 1989 has helped increase interest in improving the efficiency of electricity use. PAESE (Programa de Ahorro de Energía en el Sector Eléctrico), a program within CFE designed to promote the efficient use of electricity, has organized annual seminars on energy conservation, produced educational materials, and promoted various energy-saving measures like cogeneration in industry, better use of air conditioning in the hottest zones of the country, industrial energy audits, efficient lighting in the residential and commercial sectors and increased use of more efficient irrigation pumps. Funding for PAESE projects is now obtained from FIDE (Fideicomiso en apoyo al PAESE), a private trust fund established in 1990. FIDE's budget amounts to $0.7 \%$ of all CFE contracts and is based on contributions from CFE, its unions, and the contractors.

CFE is now in the process of negotiating a loan and grant package from the World Bank and its Global Environment Facility for a project to disseminate over 1.5 million compact fluorescent lamps in the homes of Guadalajara and Monterrey during 1994 and 1995. The extensive experience gained by PAESE in smaller residential lighting programs throughout Mexico has been incorporated (together with that of US utility consultants) into this larger project.

\subsection{Conclusion}

CFE's projection of $42 \mathrm{GW}$ of capacity by the year 2000 is probably too large. Economic and electricity growth during the past two years have been about $50 \%$ less than expected. CFE is trying to understand this reduction of growth in demand. Projections for future demand have been reduced in the yearly POISE plans for the past few years. Financing and managing this level of expansion would be difficult in any case.

Coal-fired plants using domestic coal are amongst the cheapest alternatives for electricity generation, according to CFE's estimates. These plants are also less capital-intensive than hydropower plants. The use of dual-fuel power plants that can be operated with fuel oil or imported coal is designed to allow flexibility with respect to fluctuations in international oil prices.

As for nuclear power, the second Laguna Verde unit is expected to go on line in 1995. Further expansion of nuclear power seems very improbable due to the cost overruns, safety issues, and increasing public opposition. 
In general, the result of difficulties in bringing new capacity on line may be greater-than-planned use of oil.

The Mexican power sector may see increased non-CFE generation, privatization of investment, and trade with the U.S. during the 1990s. New legislation of December, 1992, clarified the rules for independent electric power production and self generation in order to entice more self-generation and independent power producers. Since legislation was passed in 1990 permitting non-CFE generation, only PEMEX and one industry (Hylsa) have installed cogeneration in their installations. Uncertainty as to the rules and prices stemmed industry's interest in cogenerating. This new legislation also created a new regulatory body to deal with issues stemming from what is hoped will be a growing participation of these non-CFE producers. In addition, current plans call for a significant portion (about $60 \%$ ) of CFE's power plant expansion to the year 2000 to be privately financed. Discussions are also being held with the U.S. utilities to enhance electricity flow capabilities between the two countries. Mexico's power sector in the next century may even be totally privatized. 


\section{ARGENTINA ${ }^{1}$}

\subsection{Introduction}

Argentina's electric power sector, along with the rest of the economy, is undergoing profound changes. Until recently, various federal and provincial agencies were fully responsible for all aspects of the electricity supply. During the past few years, however, the government has begun privatizing the power sector and dividing the functions of generation, transmission and distribution among independent agencies and companies. This structural shift has created a great deal of uncertainty as to the future direction of power development in Argentina.

Argentina's electricity transmission network is comprised of the national grid (Sistema Interconectado Nacional, or SIN) and a few minor regional grids. A large geographical area (mostly in Patagonia) with a low population density lies outside the grids and principally depends on diesel-based generation.

As of 1990, Argentina's installed capacity (excluding self-producers) had reached 15.2 GW (up from 10.1 GW in 1980), but due to the poor condition of many of the power plants, the effective capacity remains well below installed capacity. The bulk of the increase in installed capacity during the 1980 s stemmed from new hydro plants; $2.9 \mathrm{GW}$ of hydro capacity came on line during the past decade. Currently, hydroelectric and steam plants (using both gas and oil) dominate Argentina's capacity mix (Table 10-1). Nuclear power plays a modest role; the nation's second nuclear facility, a 648 MW unit, commenced operation in early 1983.

Throughout the past decade of Argentina's economic crisis GDP has fluctuated dramatically. By 1988, GDP had fallen by $6 \%$ relative to the 1980 level. Despite the economic decline, electricity generation grew at an average annual rate of 3.9\% between 1980 and 1988 . In 1989, hydroelectric generation fell due to a combination of low rainfall and damage at a major dam, chronic poor maintenance resulted in a decline in the available thermal capacity and the Atucha I nuclear power plant suffered from technical difficulties. As a result, Argentina suffered severe shortages. The government responded by implementing rolling blackouts and limiting the availability of electricity to large industries. The economic and electricity situation has since improved; generation increased by $6.6 \%$ in 1991 and GDP rose by about $5.5 \%$. However, Argentina still suffers from a poorly maintained power base and low availability of public capital for investment in new facilities, while the economic reforms are likely to lead to renewed growth in electricity demand.

The industrial sector accounts for $45 \%$ of Argentina's electricity consumption, followed by the residential sector with $29 \%$. Over the past decade, however, the fastest growth in electricity demand has stemmed from the commercial sector.

\footnotetext{
'Based on material prepared by Gautam S. Dutt, Consultant, Buenos Aires.
} 
Table 10-1. Argentine Power Sector Statistics

\begin{tabular}{|c|c|c|}
\hline & 1990 & $\begin{array}{l}\text { AAGR } \\
1980-90\end{array}$ \\
\hline Installed Capacity (MW) & $15213(100.0 \%)$ & $4.2 \%$ \\
\hline Hydro & $6473(42.5 \%)$ & $6.0 \%$ \\
\hline Nuclear & $1018(6.7 \%)$ & $10.7 \%$ \\
\hline Thermal & $7722(50.8 \%)$ & $2.4 \%$ \\
\hline Steam & $4750(31.2 \%)$ & $2.2 \%$ \\
\hline Gas Turbine & $2289(15.0 \%)$ & $4.2 \%$ \\
\hline Diesel & $683(4.5 \%)$ & $-1.4 \%$ \\
\hline Generation (GWh) & $47009(100.0 \%)$ & $2.8 \%$ \\
\hline Hydro & $18075(38.4 \%)$ & $1.8 \%$ \\
\hline Nuclear & $7281(15.4 \%)$ & $12.0 \%$ \\
\hline Thermal & $21653(46.0 \%)$ & $1.7 \%$ \\
\hline Steam & $16448(34.9 \%)$ & $0.6 \%$ \\
\hline Gas Turbine & $4721(10.0 \%)$ & $9.6 \%$ \\
\hline Diesel & $484 \quad(1.0 \%)$ & $-7.1 \%$ \\
\hline Consumption (GWh) & $36110(100.0 \%)$ & $2.1 \%$ \\
\hline Industrial & $16188(44.8 \%)$ & $1.6 \%$ \\
\hline Residential & $10543(29.2 \%)$ & $1.8 \%$ \\
\hline Commercial & $8770(24.3 \%)$ & $3.9 \%$ \\
\hline Agriculture & $388 \quad(1.1 \%)$ & $-2.0 \%$ \\
\hline Transportation & $220(0.6 \%)$ & $-1.7 \%$ \\
\hline
\end{tabular}

Source: LBL Database, from Argentine sources

The privatization process that is currently under way poses new questions regarding the future of Argentina's power sector. During 1992, the activities of SEGBA, which formerly operated a number of natural gas and fuel oil plants and distributed electricity in Greater Buenos Aires and the neighboring city of La Plata, and AyEE, the nation's major generating and transmission agency, were passed down to provincial governments and private companies. The two bi-national hydroelectric commissions -- Salte Grande (with Uruguay) and the giant hydroelectric project under construction, Yacyretá (with Paraguay) -- have not yet been privatized. After an extended debate over whether or not to privatize the Atomic Energy Commission, which manages the nation's two nuclear power plants, the government announced plans to do so in October 1992. 
The government still maintains two major roles in the power sector: the regulation of electricity and operation of the national load dispatch. Federal commissions have been created to oversee the newly privatized power sector, and operation of the national load dispatch has been transferred to a new government agency, CAMME S.A. (Compania Administradora Mercado Mayorista Electrico), which eventually may be partially privatized. However, under the new scheme, the government no longer schedules the construction of new power plants beyond those currently under construction or makes plans for financing new plants. Thus, the fate of those power plants currently under construction now lies in the hands of the new generating companies. In addition, the new set-up will affect investment and financing decisions for the construction of power plants and associated transmission and distribution systems to be built over the longer term.

\subsection{Resources for Electricity Generation ${ }^{2}$}

Argentina has substantial untapped hydroelectric potential; gross exploitable hydro generation has been estimated at $390,000 \mathrm{GWh} /$ year. Argentina's natural gas reserves, estimated at 579 billion cubic meters at the end of 1990, may play an expanded role in electricity generation in the future. Proved recoverable reserves of crude oil are somewhat modest at 215 million tonnes. Argentina has 11,000 tonnes of proved uranium reserves recoverable at less than US\$130/kg.

\subsection{Scenarios of Electricity Demand and Supply}

The government no longer develops official projections of future electricity demand. This section presents long-term visions of Argentina's power sector from three other sources: three scenarios presented by the Atomic Energy Commission to help assess the need for nuclear power plants, an unofficial projection developed by the Energy Secretary to facilitate the privatization process; and projections by the FIEL (Fundación de Investigaciones Económicas Latinoamericanas), an economic research institute, developed for the purpose of determining investment requirements for infrastructure development in Argentina between 1992-2000.

Presently, the most important projects being built are (1) the 1400 MW Piedra del Aquila power plant in the Andes, (2) the giant $2700 \mathrm{MW}$ Yacyreta hydroelectric power plant on the upper Paraná river, (3) the 745 MW Atucha II nuclear power plant, and (4) the 250 MW Pichi Picùn Leufû hydroelectric power plant also in the Andes. Piedra del Aquila is virtually complete and should go on line early in 1993. The construction of Yacyretá and Atucha II are both well advanced, but projected additional investment requirements are still high ( $\$ 2.1$ and $\$ 1.2$ billion respectively). ${ }^{3}$ The World Bank has extended US\$ 300 million towards Yacyretá, signalling that they perceive it to be a better investment. The fate of Atucha II, and of the Atomic Energy

\footnotetext{
${ }^{2}$ From: World Energy Council, 1992 Survey of Energy Resources (Oxford: Holywell Press Ltd), 1992.

${ }^{3}$ Nthough two of the studies presented below assume that Atucha II will come on line in 1995 or 1996, recent sources indicace that it is unlikely to come on line before 1997.
} 
Commission in general, is more uncertain. The problematic history of these projects and the strong emphasis now placed on fiscal control of the economy suggest that delays are likely.

\section{The Atomic Energy Commission (AEC) Projection ${ }^{4}$}

Given the uncertainties in the evolution of economic activity in Argentina, the AEC developed three different demand projections: crisis, minimum and maximum. Because the main focus of the study was to assess the need for further nuclear power development, the projections only considered baseload demand.

As indicated in Table 10-2, th. crisis scenario assumes that Argentina's problems continue until the end of the century. The electricity demand grows by $3.6 \%$ per year between 1992 and 2005, mirroring the average rate of the 1980s, and baseload requirement reaches 8.2 $\mathrm{GW}$ in 2000 . With notably higher GDP and electricity demand growth, the minimum scenario foresees baseload requirement reaching $9.3 \mathrm{GW}$ in 2000 . The maximum scenario assumes that GDP grows by $6.2 \%$ /year and electricity demand by $8.6 \%$ /year between 1992 and 2005 . Baseload demand soars in this scenario to $12.4 \mathrm{GW}$ in 2000 .

Table 10-2. AEC Demand Projection, 1992-2005

\begin{tabular}{|c|c|c|c|c|}
\hline \multirow[t]{2}{*}{ Scenario } & \multirow{2}{*}{$\begin{array}{c}\text { GDP Growth Rate } \\
(\% / y r) \\
1992-2005\end{array}$} & \multirow{2}{*}{$\begin{array}{c}\text { Electricity Demand } \\
\text { Growth Rate (\%/yr) }\end{array}$} & \multicolumn{2}{|c|}{$\begin{array}{c}\text { Baseload } \\
\text { Demand } \\
\text { Requirement } \\
\text { (GW) }\end{array}$} \\
\hline & & & 2000 & 2005 \\
\hline Crisis & $0.7 / 0.9^{b}$ & 3.6 & 8.2 & 10.3 \\
\hline Minimum & 3.7 & 6.3 & 9.3 & 12.7 \\
\hline Maximum & 6.2 & 8.6 & 12.4 & 19.4 \\
\hline
\end{tabular}

Notes: a. Includes a reserve margin of $20 \%$.

b. GDP growth is assumed to average $0.7 \% /$ year in $1992-2000$ and $0.9 \% / y r$ in $2000-2005$.

Source: Mariano et al. 1992.

The AEC projects future installed baseload capacity by estimating the capacity to be added from the power plants currently under construction, as well as from several potential projects, and the capacity to be retired from existing power plants. Three hydroelectric plants, three repowered steam-turbine power plants, two thermal power plants and the Atucha II nuclear

\footnotetext{
4 This projection comes from two sources. The demand projection is from: Mariano, E., W. Baran and E. Quiles, The Situación Eléctrica Argentina y su Posible Evolución en el Mediano Plazo (The Current Status of Electricity in Argentina and its Possible Evolution in the Medium Term), Comite de Análisis del Programa Nucleoeléctrico para el Modelo Energético Nacional, Comisión Nacional de Energía Atómica, 1992. The long-term capacity projection is from: Mariano, Enrique, Necesidad de Ingreso a la Red de la Central Nuclear Atucha II (The Need for Connecting the Atucha II Nuclear Power Plant to the Grid), Comite de Análisis del Programa Nucleoeléctrico para el Modelo Energético Nacional, Comisión Nacional de Energía Atómica, 1992.
} 
power plant are projected to come on line between 1992 and 1998. No additional facilities are included beyond 1998. Based on these plans, Argentina will have a total installed baseload capacity of $9.4 \mathrm{GW}$ in 2000 and of $8.8 \mathrm{GW}$ in 2005 (Table 10-3). ${ }^{5}$ Without the Atucha II nuclear plant, total baseload capacity will reach $8.7 \mathrm{GW}$ in 2000 and $8.1 \mathrm{GW}$ in 2005 .

Table 10-3. AEC Power Development Scenario, 1991-2000

\begin{tabular}{lcc}
\hline & 1991 & 2000 \\
\hline \hline Existing Baseload Capacity (GW) & 5808 & 5111 \\
Additional Baseload Capacity (GW) & 4293 \\
Piedra del Aquila (hydro) & 703 \\
Yacyretá (hydro) & 2200 \\
Atucha II (nuclear) & 680 \\
Otherb & 710 \\
Total Baseload Capacity (GW) & 5808 & 9404 \\
\hline \hline
\end{tabular}

Notes: a. Assumes $697 \mathrm{MW}$ of existing capacity are retired between 1991 and 2000 .

b. Other includes Urugua-í (hydro - $45 \mathrm{MW}$ ), Güemes 3 and Luján de Cuyo (thermal $115 \mathrm{MW}$ and $100 \mathrm{MW}$ ), and Puerto Nuevo 9, Costanera 1 and Costanera 5 (repowered steam turbine - $230 \mathrm{MW}, 110 \mathrm{MW}$ and $110 \mathrm{MW}$ ).

Source: Mariano 1992.

Only in the crisis scenario is there no need for Atucha II in the year 2000. In the minimum scenario, the power plants under construction or projected will be sufficient to meet the demand only through the year 1998, making it essential for Atucha II to come on line beginning in 1999. If no additional power plants are added, the electricity deficit will reach $4000 \mathrm{MW}$ by the year 2005 . In the maximum scenario, the deficit is nearly $3000 \mathrm{MW}$ in the year 2000 even with Atucha II. By the year 2005, the deficit rises to over $10,000 \mathrm{MW}$, implying the need for substantial additions to the power base beyond the currently planned facilities. Thus, while the AEC projections suggest that there is a possibility that the currently planned mix of plants would be sufficient to satisfy Argentina's electricity needs over the next decade, if Argentina's economic picture brightens more capacity would have to come on line.

The Energy Secretariat Projection (SEE) ${ }^{6}$

\footnotetext{
${ }^{5}$ By the turn of the century, Atucha I, an existing $370 \mathrm{MW}$ nuclear facility, will have reached the end of its useful life.

${ }^{6}$ Subsecretaria de Energía Eléctrica (SEE), Perspectivas de Mediano y Largo Plazo (Medium-and Long-term Perspectives), 1992 (developed for the negotiations on privatization of the electric power sector, by Lic. Landy; this document is not an official projection of the Energy Secretary).
} 
The SEE projection assumes that GDP grows at an average annual rate of $4.1 \%$ year between 1993 and 2000 . The annual growth rate of electricity consumption averages $6.4 \% /$ year, bringing total electricity demand to $75.2 \mathrm{GWh}$ in 2000 (Table 10-4).

Table 10-4. SEE Projections of Electricity Demand (GWh) by Sector, 1991-2000

\begin{tabular}{lcc}
\hline \hline Sector & 1991 & 2000 \\
\hline \hline Residential & $11.3(29 \%)$ & $16.4(23 \%)$ \\
Commercial & $3.5(9 \%)$ & $8.2(12 \%)$ \\
Industrial & $22.3(48 \%)$ & $43.7(55 \%)$ \\
Other & $5.0(14 \%)$ & $6.9(10 \%)$ \\
Total & $42.1(100 \%)$ & $75.2(100 \%)$ \\
\hline \hline
\end{tabular}

Source: SEE 1992.

Table 10-5 shows SEE's projections for capacity additions, which differ somewhat from the Atomic Energy Commission's projections. According to SEE, Yacyretá has an installed capacity of $3100 \mathrm{MW}$ vs. the AEC's estimate of $2700 \mathrm{MW}$ (2200 MW baseload). Instead of the $120 \mathrm{MW}$ hydroelectric plant Urugua-i included by the AEC, SEE includes the $250 \mathrm{MW}$ hydroelectric plant, Pichi Picùn Leufu. Whereas the AEC includes two small thermal plants in 1992 and 1993 respectively and three repowered steam-turbine power plants, SEE instead opts for three combined-cycle power plants (each $300 \mathrm{MW}$ ) coming on line in the year 2000.

Table 10-5. SEE Power Development Scenario, 1993-2000

\begin{tabular}{lcccc}
\hline & \multicolumn{2}{c}{ Generation* (TWh) } & & Installed Capacity (MW) \\
\cline { 2 - 3 } & 1993 & 2000 & 2000 \\
\hline Existing plants & 51.0 & $41.0^{\mathrm{b}}$ & \\
Additional plants & & 36.1 & \\
Piedra del Aquila (hydro) & 3.0 & 5.7 & 1400 \\
Yacyretá (hydro) & & 18.9 & 3100 \\
Atucha Il (nuclear) & & 5.2 & 745 \\
Pichi Picùn Leufû (hydro) & & 1.1 & 250 \\
Combined-cycle plants & 5.1 & $3 \times 300$ \\
Total & & 77.1 & \\
\hline \hline
\end{tabular}

Notes: a. For average hydrological years.

b. Assumes plants generating 9.5 TWh of electricity in 1993 are retired by 2000 .

Source: SEE 1992 
Unlike the AEC study, SEE does not explicitly identify which individual power plants are removed. SEE's estimate shows total generation rising to $77.1 \mathrm{TWh}$ in 2000 , which would be only 1.9 TWh above projected demand. Thus, this analysis suggests that additional generating capacity will probably be required if moderate GDP growth occurs.

\section{The FIEL Projection?}

The Latin American Economic Research Foundation (Fundación de Investigaciones Económicas Latinoamericanas or FIEL) is an economic research institute known for the quality of its research and its support of economic deregulation and the privatization of key sectors of Argentine industry. The study referred to here forms part of a larger study to determine investment requirements for infrastructure development in Argentina for the rest of the century.

The FIEL study expects that the current structural reforms in the Argentine economy will stimulate GDP growth rates of 6-8\%/year. FIEL provides high and low scenarios with annual growth rates in electricity demand of $8 \%$ and $4 \%$ respectively. ${ }^{8}$ Peak demand in 2000 reaches $12 \mathrm{GW}$ in the low scenario and $16 \mathrm{GW}$ in the high scenario. Assuming a reasonable reserve margin, FIEL estimates that Argentina will require installed capacity of $14.5 \mathrm{GW}$ and $19.2 \mathrm{GW}$ in the low and high scenarios respectively (Table 10-6). ${ }^{9}$

Table 10-6. FIEL Demand Projections for Argentina, 1992-2000

\begin{tabular}{lll}
\hline \hline & 1992 & 2000 \\
\hline $\begin{array}{l}\text { Peak Demand (MW) } \\
\text { Low scenario (4\%) }\end{array}$ & 8911 & 12121 \\
High scenario (8\%) & 9089 & 16017 \\
Capacity Required (MW) & 11317 & 14545 \\
Low scenario (4\%) & 11543 & 19220 \\
High scenario (8\%) & \\
\hline
\end{tabular}

\footnotetext{
${ }^{7}$ Fundación de Investigaciones Económicas Latinoamericanas (FIEL), Inversión en infraestructura en Argentina: 1992-2000, parte IV: Sector Eléctrico, Buenos Aires, May 1992.

${ }^{8}$ In considering electricity demand, FIEL argues that the correlation between GDP and electricity consumption growth during the past decade cannot be used as a basis for projecting future trend in electricity demand. One reason is that the increase in energy use from the informal sector was included in national accounts, but the increase in economic activity went unrecorded.

9 The scenarios assume that growing availability of a reliable electricity supply results in lower levels of self-generation in the future. In the year 2000 , FIEL estimates that $2000 \mathrm{GWh}$ of electricity will be self-generated in Argentina, down from 4000 GWh in 1991 .
} 
This analysis determines the capacity of existing power plants based on the weighted average of plant availability. The hydroelectric and nuclear power plants currently under construction are added to the estimates of available capacity as they come on line. Based on this assessment, FIEL estimates the capacity deficit and then identifies a three-stage process for reducing it:

(1) by reconditioning existing steam power plants, at an estimated cost of less than $\$ 100$ per $\mathrm{kW}$;

(2) by adding two new combined-cycle power plants (285 MW and $570 \mathrm{MW}$ ), located at wellhead, in 1998 and 1999 respectively (the SEE projection also includes about the same capacity in combined-cycle plants); and

(3) by repowering the low-power steam power plants. Presently Argentina has 24 steam turbines with capacities below $50 \mathrm{MW}$ (their combined capacity is $500 \mathrm{MW}$ ) and 13 steam turbines with capacities between 60 and $70 \mathrm{MW}$. The FIEL projection assumes that gas turbines could be added to $60 \%$ of these units, increasing the total power output three-fold. The cost would not exceed $\$ 500 / \mathrm{kW} .{ }^{10}$ The FIEL study states that this measure would provide $1700 \mathrm{MW}$ of installed capacity and a maximum output of 12 TWh.

The strengths of FIEL's expansion plan lie in the low capital costs and the potential for rapid installation. This plan offers additional flexibility in the face of further delays in the construction of Yacyretá and Atucha II.

\section{Summary}

The FIEL study does not provide sufficient data to develop a detailed picture of future electricity generation in Argentina. The AEC and SEE studies both designate the types and installed capacities of the plants to be built through 2000. The AEC study also designates the capacity to be retired from existing plants. Based on the assumption that the same capacity is retired in the SEE scenario as in the AEC projection, by the year 2000 total installed capacity increases to $20.2 \mathrm{GW}$ according to the AEC and to $21.1 \mathrm{GW}$ according to SEE (Table 10-7). In both studies, hydro's share of installed capacity increases from $43 \%$ in 1990 to $52 \%$ in 2000 . Whereas AEC's projection relies somewhat more heavily on steam and gas-turbine/diesel plants, the SEE scenario instead integrates combined-cycle facilities. Both projections foresee a decrease in the overall shares of steam-fired and gas-turbine plants in the capacity mix (Figure 10-1).

All three studies indicate that by the turn of the century there is a strong probability that Argentina will require more installed capacity than will be available based on current

\footnotetext{
${ }^{10}$ Although the international value is below $\$ 400 / \mathrm{kW}$, FIEL assumes that construction costs are higher in Argentina.
} 


\section{Argentina Power Development Plans Installed Capacity}

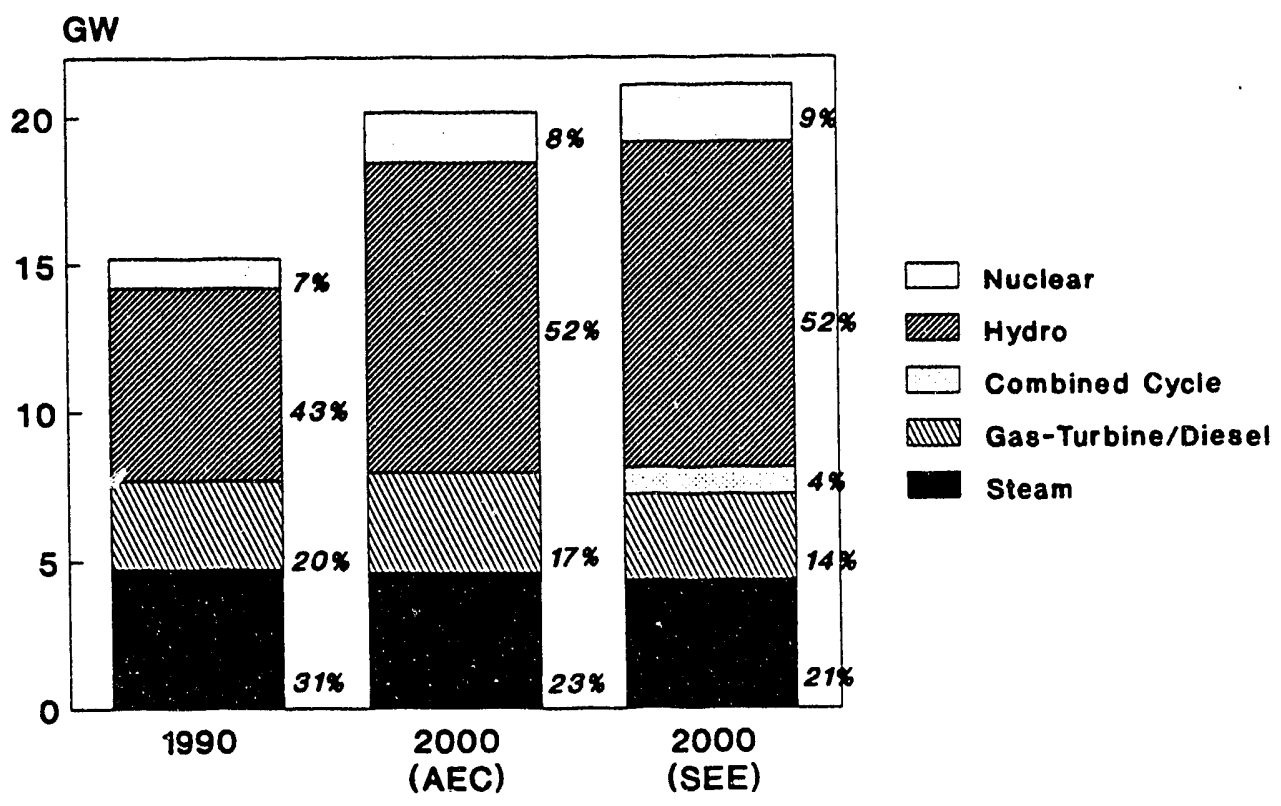

Figure 10-1 
construction plans. Of the projections presented above, only the crisis scenario of the AEC study would require no increase in installed capacity beyond what would be provided by those plants currently under construction. FIEL's low-growth scenario also implicitly indicates that the current construction plans would require sufficient capacity through the turn of the century. It is important to note, however, that none of the long-term scenarios incorporate demand-side management into their projections; such measures could substantially diminish the requirements for additional plants.

Table 10-7. Projections of Argentina's Installed Capacity (GW), 2000

\begin{tabular}{lccc}
\hline & 1990 & \multicolumn{2}{c}{$2000^{\circ}$} \\
\cline { 3 - 4 } & & \multicolumn{2}{c}{ Based on: } \\
\cline { 3 - 4 } & & AEC & SEE \\
\hline \hline Hydro & 6.47 & 10.48 & 11.01 \\
Steam (Oil/gas) & 4.75 & 4.61 & 4.36 \\
Nuclear & 1.02 & 1.70 & 1.95 \\
Gas-Turbine/Diesel & 2.97 & 3.36 & 2.87 \\
Combined Cycle & 0.00 & 0.00 & 0.90 \\
Total & 15.21 & 20.15 & 21.09 \\
\hline \hline
\end{tabular}

Note: $\quad$ a. Assumes retirement of $0.70 \mathrm{GW}$ capacity between 1990 and $2000(0.21$ GW hydro, $0.10 \mathrm{GW}$ gas-turbine/diesel and $0.39 \mathrm{GW}$ steam) given in the AEC scenarios. The two sources assume different installed capacities of projects currently under construction.

Sources: $\quad$ Based on Mariano 1992 and SEE 1992.

\subsection{Financial Issues}

The Atomic Energy Commission does not provide figures for investment costs for future power development.

A separate Energy Secretary projection provides estimates of investment requirements for power plants now under construction between 1992-98. ${ }^{11}$ The total comes to just under $\$ 5$ billion, of which $\$ 0.5$ billion is for power transmission for two of the hydroelectric plants under construction.

FIEL provides estimates of investment requirements for generation, transmission and distribution for its high and low scenarios. Total investment requirements for the 1992-2000 period are $\$ 6.8$ billion in the low scenario and $\$ 10.3$ billion in the high scenario (Table 10-8).

"Cora Kamman, personal communication, 1992. 
FIEL's estimate of investment requirements for plants under construction is lower than the Energy Secretary data by $\$ 0.37$ billion. ${ }^{12}$ Using more recent Energy Secretary data, FIEL's estimates of total investment requirements rise to $\$ 7.2$ and $\$ 10.6$ billion respectively.

An estimate of total investment requirements in the Argentine power sector of $\$ 10$ billion appears in a November 25, 1992 press release of EDENOR, the newly formed distribution company which supplies the northern half of Greater Buenos Aires. They estimate that the private sector will be responsible for $60 \%$ of this total.

Table 10-8. FIEL's Projected Investment Requirements for the Argentine Power Sector, 1992-2000

\begin{tabular}{lc}
\hline & USS million \\
\hline Plants under construction & 1899 \\
Yacyretá (H) & 1103 \\
Atucha II (N) & 562 \\
Other hydro & \\
f.dditional plants & 380 \\
Low scenario (4\%) & 1953 \\
High scenario (8\%) & \\
Transmission and distribution & 2592 \\
Low scenario (4\%) & 4451 \\
High scenario (8\%) & \\
Total & 6825 \\
Low scenario (4\%) & 10258 \\
\hline High scenario (8\%) & \\
\hline Note: a. Includes \$290 million in miscellaneous items. & \\
Source: FIEL 1992. & \\
\hline
\end{tabular}

Given the privatization of the electric power sector in Argentina, future investment sources will likely be quite different than those in the past. All investments except those for completing the hydro and nuclear power plants now being built will probably come from the private sector. The companies that have purchased the various portions of SEGBA represent a wide range of entities, from private Argentine petroleum companies (such as Astra) to the French national Electricité de France. While it is reasonable to assume that their capital will derive from international capital markets, it is uncertain how the government will get the capital it requires. The recent $\$ 300$ million (additional) loan from the World Bank for Yacyretá suggests a confidence in the Argentine economy and a willingness to see the project through to

\footnotetext{
12 The SEE study estimates the investment to be $\$ 2140$ million for Yacyretá, \$1203 for Atucha II and \$593 million for the other hydro plants.
} 
completion. The Inter-American Development Bank also may provide funds. Finally, the government may well put in some of its own resources, especially for finishing Atucha II. There is also the possibility that the goverrment will transfer some of the hydroelectric power plants now under construction to the private sector in order to alleviate their financial burden.

\subsection{Environmental Considerations}

The expected power expansion includes two very large hydro plants, one nuclear facility and a number of natural gas-fired thermal plants. To date, the environmental aspects of power plant construction have not emerged as an area of serious public concern in Argentina. However, proponents of nuclear power in Argentina argue that nuclear facilities are far less polluting than fossil fuel plants and thus should play a greater role in future power development plans. $^{13}$

Argentina's largest hydroelectric projects are located on the Limay and Neuquén river basins. In the past, the construction of dams along these two rivers has resulted in the displacement of large populations -- many of whom are indigenous or tribal peoples -- who have benefitted little from the projects. Flooding for the Salto Grande Dam required the relocation of 5,000 people on the Argentine side and 8,000 people on the Uruguay side. The relocation on the Uruguay side was carried out under hostile circumstances. The largest hydroelectric power plant under construction in Argentina, the Yacyretá, is located on a plains river and will require extensive flooding. About 40,000 people in Argentina and Paraguay are expected to be dispiaced.

The environmental and social impacts of large hydroelectric projects have been of far greater concern to the international environmental community than to energy planners within Argentina. The Environmental Protection Agency has done some research on the possibilities of promoting conservation as a means for offsetting the need for the Yacyretá Dam or for reducing the flooded area. The U.S. Treasury Department also recently investigated the environmental impacts of the Dam.

\subsection{Electricity Supply and End-Use Efficiency}

The efficiency of Argentina's thermal plants averaged $28-29 \%$ in 1988 . The relative inefficiency of thermal generation in Argentina stems from systemic factors, such as the heavy reliance on gas-turbine generation, as well as from the poor condition of many of the steam plants. Transmission and distribution losses are quite high, at $18 \%$ in 1988, indicating room for considerable improvement.

\footnotetext{
${ }^{13}$ Mariano, op cit., Ref. 4.
} 
Although there has yet to be detailed analysis, evidence from Brazil ${ }^{14}$ suggests that there are many low-cost demand-side management (DSM) measures for Argentina that are cheaper than the supply-side options being considered. Such measures have the potential to greatly reduce future demand. Considering that the completion of power plants currently under construction and the low-cost supply increase options considered in the FIEL study are likely to satisfy demand until 1998 even without any DSM, by putting DSM programs into motion in the next six years Argentina could offset the need for new power plants at the turn of the century.

\subsection{Conclusion}

The current changes in the power sector will affect investment and financing decisions for the construction of power plants and associated transmission and distribution systems. In the past decade, most of Argentina's new capacity was high capital cost (and low operating cost) hydro and nuclear plants. The FIEL study found that over the period 1970-91, Argentina invested around $\$ 6,600$ per $\mathrm{kW}$ of demand increase, several times higher than international norms. The new generating companies will favor much lower capital cost options. They are expected to concentrate on repairing and/or repowering many existing natural gas and fuel oilfired steam-turbine power plants, in some cases by adding a gas-turbine topping cycle. Later in the decade, a number of combined-cycle power plants may need to be built to meet supply shortfalls.

If all power plants currently under construction are completed and the essential reconditioning of many existing power plants takes place, total investment requirements for the electric power sector will be around US\$ 7 billion until the year 2000 . The available electricity supply will be able to meet a $4 \%$ /year demand growth rate until 2000 . An upper limit on demand growth of around $8 \%$ year would require additional repowering of some steam turbine power plants with gas-turbine topping cycles, and the installation of new combined-cycle plants. Total investment requirements would then be around US\$ 10 billion. Thus even without any significant DSM programs, no large power plants would be needed until after the year 2000 . With such programs, the combined-cycle power plants could be postponed and no large power plants would be needed until well into the next century.

\footnotetext{
14 Geller, Howard S., Efficent Electricity Use: A Development Strategy for Brazil (Washington, D.C.: American Council for an Energy-Efficient Economy), 1991.
} 


\section{SUMMARY AND CONCLUSION}

\subsection{Introduction}

Over the past decade, the power sector in the developing world has evolved considerably. Installed generating capacity expanded at varying rates in the nine countries examined in this report between 1980 and 1990, based largely on economic factors and resource constraints. As shown in Table 11-1, the average annual growth rate of installed capacity ranged from a low of $4.1 \%$ in the Philippines to a high of $13.6 \%$ in Indonesia. In total, these nine countries witnessed a two-fold increase in installed capacity between 1980 and 1990.

The electricity-generating mix has also undergone tremendous shifts. Galvanized by the oil price shocks, most of these countries have diversified their power base, turning to indigenous resources whenever possible. Particularly in countries such as Taiwan and South Korea, where indigenous resources are scarce, nuclear power has witnessed substantial growth. Fossil fuels still dominate power generation in these countries. While the role of oil diminished considerably during much of the 1980s, in more recent years the combination of lower prices and rising slectricity demand have led to greater oil use.

As these countries confront the next decade of power development, they face new challenges. The supply of easily exploitable indigenous power resources has shrunk in most of these nations, environmental issues -- local, regional and global -- have taken on growing importance, and the capital necessary for expanding the power base has become increasingly scarce. This section summarizes the outlook for the power sector in the year 2000 in China, India, Indonesia, Thailand, the Philippines, South Korea, Taiwan, Argentina and Mexico, and assesses the feasibility of their long-term power development plans given the growing financial, environmental and institutional constraints.

\subsection{Installed Capacity}

Table 11-1 shows the planned growth in installed electric power capacity and the implicit future rates of average annual growth between 1991 and 2001 (early 1997 in the case of India). In absolute terms, China and India account for the vast majority of the growth. The future rates of growth range from a low of $3.3 \%$ per year in Argentina to a high of $13.2 \%$ per year in Indonesia. Based on these projections, the combined installed capacity of these nine countries in the year 2000 would be around $630 \mathrm{GW}$, which is still less than the electricity-generating capacity currently installed in the United States $(720 \mathrm{GW})$.

Table 11-2 shows the planned growth in installed capacity by fuel type. In most of the countries, fossil fuels provide most of the new capacity. The movement away from oil continues over the next decade in nearly every country, although the actual use of oil for electricity generation may well turn out to be higher than planned if large power projects based on other energy sources are delayed. The plans call for a modest expansion of oil-fired capacity in 
Indonesia, Thailand ${ }^{1}$ and the Philippines, and of dual-fuel oil/gas capacity in Mexico. Thailand is leaving open the option of using fuel oil rather than imported coal in some of its planned thermal plants if prices are favorable. Other countries may choose to do the same.

\begin{tabular}{|c|c|c|c|c|}
\hline & \multicolumn{2}{|c|}{ Installed Capacity (GW) } & \multicolumn{2}{|c|}{ Average Annual Growth (\%) } \\
\hline & $\begin{array}{c}1991 \\
\text { Actual }\end{array}$ & $\begin{array}{l}2000 / 01^{*} \\
\text { Planned }\end{array}$ & $\begin{array}{c}1980-1990 \\
\text { Actual }\end{array}$ & $\begin{array}{l}1991-2000 / 01^{\circ} \\
\text { Planned }\end{array}$ \\
\hline China & 151.5 & $280-300$ & 7.7 & 7.5 \\
\hline India & 69.6 & $92.8^{\mathrm{b}}$ & 7.8 & $6.0^{\infty}$ \\
\hline Indonesia & 9.2 & $31.8^{\mathrm{c}}$ & 13.6 & $13.2^{\mathrm{c}}$ \\
\hline South Korea & 21.1 & 46.9 & 8.4 & 8.3 \\
\hline Taiwan & 18.4 & 37.5 & 6.4 & 7.4 \\
\hline Thailand & 9.6 & 22.8 & 9.7 & 9.0 \\
\hline Philippines & 6.8 & 11.9 & 4.1 & 6.4 \\
\hline Mexico & 26.8 & 42.0 & 5.6 & 5.1 \\
\hline Argentina $^{d}$ & 15.2 & 21.1 & 4.2 & 3.3 \\
\hline
\end{tabular}

Notes: a. The end year varies among the countries.

b. The end year is FY 1996.

c. Refers to mid-point of moderate and high scenarios.

d. We estimated year-2000 capacity based on unofficial scenarios.

The base year is 1990 .

Reflecting its relative inexpensiveness and availability, coal use in electricity generation witnesses a tremendous absolute increase. China's plans call for a net increase of some 80-100 GW in coal capacity. In India, coal accounts for over half the growth in installed capacity between 1991 and 1996. The capacity mix shifts toward coal in Indonesia, South Korea, Taiwan, Thailand, Mexico and the Philippines as well. Except for in China and India, which have abundant indigenous coal supplies, imports will satisfy the bulk of the coal demand.

The use of natural gas is expected to increase most substantially in Indonesia and Taiwan, and to a lesser degree in India and South Korea. In both Indonesia and India, the availability of indigenous natural gas supplies drives the shift (although India may also come to rely on imported LNG if the government permits the use of hard currency for imports). In Taiwan and South Korea, where imported LNG is already significant, the relative cleanliness of gas is a key factor behind its growing use. While Thailand plans to expand its gas-fired capacity, the role of gas in the mix will decline in favor of imported coal due to the lack of indigenous gas supplies.

\footnotetext{
"The capacity listed under "oil/gas" in Table 11-2 is primarily gas-fured.
} 


\begin{tabular}{|c|c|c|c|c|c|c|c|c|c|c|}
\hline \multicolumn{11}{|c|}{$\begin{array}{l}\text { Table 11-2. Actual and Planned Installed Electric Power Capacity } \\
\text { (Not including self-producers) }\end{array}$} \\
\hline & Year & Coal & Oil & Gas & Coal/oil & Oil/gas & Hydro & Nuclear & Geo. & Total \\
\hline \multicolumn{11}{|c|}{ GIGAWATTS } \\
\hline China & $\begin{array}{l}1991 \\
2000\end{array}$ & $\begin{array}{c}113 \\
194-214\end{array}$ & $\begin{array}{l}0.0 \\
?\end{array}$ & $\begin{array}{l}0.0 \\
?\end{array}$ & $\begin{array}{l}0.0 \\
0.0\end{array}$ & $\begin{array}{l}0.0 \\
0.0\end{array}$ & $\begin{array}{l}38.0 \\
80.0\end{array}$ & $\begin{array}{l}0.3 \\
6.0\end{array}$ & $\begin{array}{l}0.0 \\
0.0\end{array}$ & $\begin{array}{c}151.3 \\
280-300\end{array}$ \\
\hline India & $\begin{array}{l}1991 \\
1996\end{array}$ & $\begin{array}{l}44.3 \\
56.6\end{array}$ & $\begin{array}{l}0.0 \\
0.0\end{array}$ & $\begin{array}{l}3.9 \\
8.6\end{array}$ & $\begin{array}{l}0.0 \\
\Gamma .0\end{array}$ & $\begin{array}{l}0.0 \\
0.0\end{array}$ & $\begin{array}{l}19.4 \\
24.8\end{array}$ & $\begin{array}{l}2.0 \\
3.2\end{array}$ & $\begin{array}{l}0.0 \\
0.0\end{array}$ & $\begin{array}{l}69.6 \\
92.8\end{array}$ \\
\hline Indonesia & $\begin{array}{l}1991 \\
2001\end{array}$ & $\begin{array}{l}1.7 \\
9.9\end{array}$ & $\begin{array}{l}5.2 \\
5.3\end{array}$ & $\begin{array}{l}0.0 \\
6.1\end{array}$ & $\begin{array}{l}0.0 \\
0.0\end{array}$ & $\begin{array}{l}0.0 \\
0.0\end{array}$ & $\begin{array}{l}2.1 \\
6.3\end{array}$ & $\begin{array}{l}0.0 \\
0.0\end{array}$ & $\begin{array}{l}0.1 \\
0.6\end{array}$ & $\begin{array}{c}9.2 \\
28.3\end{array}$ \\
\hline South Korea & $\begin{array}{l}1991 \\
2001\end{array}$ & $\begin{array}{c}3.7 \\
15.2\end{array}$ & $\begin{array}{l}4.8 \\
4.8\end{array}$ & $\begin{array}{l}2.6 \\
6.8\end{array}$ & $\begin{array}{l}0.0 \\
0.0\end{array}$ & $\begin{array}{l}0.0 \\
0.0\end{array}$ & $\begin{array}{l}2.4 \\
4.5\end{array}$ & $\begin{array}{r}7.6 \\
15.7\end{array}$ & $\begin{array}{l}0.0 \\
0.0\end{array}$ & $\begin{array}{l}21.1 \\
46.9\end{array}$ \\
\hline Taiwan & $\begin{array}{l}1991 \\
200\end{array}$ & $\begin{array}{c}4.7 \\
11.8\end{array}$ & $\begin{array}{l}5.2 \\
5.1\end{array}$ & $\begin{array}{l}0.8 \\
8.6\end{array}$ & $\begin{array}{l}0.0 \\
0.0\end{array}$ & $\begin{array}{l}0.0 \\
0.0\end{array}$ & $\begin{array}{l}2.6 \\
4.8\end{array}$ & $\begin{array}{l}5.1 \\
7.1\end{array}$ & $\begin{array}{l}0.0 \\
0.0\end{array}$ & $\begin{array}{l}18.4 \\
37.5\end{array}$ \\
\hline Thailand & $\begin{array}{l}1991 \\
2001\end{array}$ & $\begin{array}{l}2.1 \\
3.2\end{array}$ & $\begin{array}{l}0.5 \\
1.7\end{array}$ & $\begin{array}{l}2.0 \\
4.3\end{array}$ & $\begin{array}{l}0.0 \\
4.2\end{array}$ & $\begin{array}{l}2.6 \\
3.8\end{array}$ & $\begin{array}{l}2.4 \\
3.6\end{array}$ & $\begin{array}{l}0.0 \\
0.0\end{array}$ & $\begin{array}{l}0.0 \\
0.0\end{array}$ & $\begin{array}{c}9.6 \\
22.8\end{array}$ \\
\hline Philippines & $\begin{array}{l}1991 \\
2000\end{array}$ & $\begin{array}{l}0.4 \\
2.9\end{array}$ & $\begin{array}{l}3.3 \\
4.3\end{array}$ & $\begin{array}{l}0.0 \\
0.0\end{array}$ & $\begin{array}{l}0.0 \\
0.0\end{array}$ & $\begin{array}{l}0.0 \\
0.0\end{array}$ & $\begin{array}{l}2.2 \\
2.5\end{array}$ & $\begin{array}{l}0.0 \\
0.7 ?\end{array}$ & $\begin{array}{l}0.9 \\
2.5\end{array}$ & $\begin{array}{c}6.8 \\
11.9\end{array}$ \\
\hline Mexico & $\begin{array}{l}1991 \\
2000\end{array}$ & $\begin{array}{l}1.2 \\
2.6\end{array}$ & $\begin{array}{l}0.0 \\
0.0\end{array}$ & $\begin{array}{l}0.0 \\
0.0\end{array}$ & $\begin{array}{l}0.0 \\
5.4\end{array}$ & $\begin{array}{l}16.3 \\
20.7\end{array}$ & $\begin{array}{r}7.9 \\
10.7\end{array}$ & $\begin{array}{l}0.7 \\
1.3\end{array}$ & $\begin{array}{l}0.7 \\
1.4\end{array}$ & $\begin{array}{l}26.8 \\
42.0\end{array}$ \\
\hline Argentina & $\begin{array}{l}1990 \\
2000 \\
\end{array}$ & $\begin{array}{l}0.1 \\
0.1 \\
\end{array}$ & $\begin{array}{l}3.0 \\
2.9 \\
\end{array}$ & $\begin{array}{l}0.0 \\
0.9 \\
\end{array}$ & $\begin{array}{l}0.0 \\
0.0 \\
\end{array}$ & $\begin{array}{l}4.6 \\
4.2 \\
\end{array}$ & $\begin{array}{r}6.5 \\
11.0 \\
\end{array}$ & $\begin{array}{l}1.0 \\
1.9 \\
\end{array}$ & $\begin{array}{l}0.0 \\
0.0 \\
\end{array}$ & $\begin{array}{l}15.2 \\
21.1 \\
\end{array}$ \\
\hline \multicolumn{11}{|c|}{ PERCENT } \\
\hline China & $\begin{array}{l}1991 \\
2000\end{array}$ & $\begin{array}{l}75 \\
70\end{array}$ & $\begin{array}{l}0 \\
?\end{array}$ & $\begin{array}{l}0 \\
?\end{array}$ & $\begin{array}{l}0 \\
0\end{array}$ & $\begin{array}{l}0 \\
0\end{array}$ & $\begin{array}{l}25 \\
28\end{array}$ & $\begin{array}{l}0 \\
2\end{array}$ & $\begin{array}{l}0 \\
0\end{array}$ & $\begin{array}{l}100 \\
100\end{array}$ \\
\hline India & $\begin{array}{l}1991 \\
1996\end{array}$ & $\begin{array}{l}64 \\
61\end{array}$ & $\begin{array}{l}0 \\
0\end{array}$ & $\begin{array}{l}6 \\
9\end{array}$ & $\begin{array}{l}0 \\
0\end{array}$ & $\begin{array}{l}0 \\
0\end{array}$ & $\begin{array}{l}28 \\
27\end{array}$ & $\begin{array}{l}3 \\
3\end{array}$ & $\begin{array}{l}0 \\
0\end{array}$ & $\begin{array}{l}100 \\
100\end{array}$ \\
\hline Indonesia & $\begin{array}{l}1991 \\
2001\end{array}$ & $\begin{array}{l}19 \\
35\end{array}$ & $\begin{array}{l}57 \\
19\end{array}$ & $\begin{array}{r}0 \\
22\end{array}$ & $\begin{array}{l}0 \\
0\end{array}$ & $\begin{array}{l}0 \\
0\end{array}$ & $\begin{array}{l}22 \\
23\end{array}$ & $\begin{array}{l}0 \\
0\end{array}$ & $\begin{array}{l}1 \\
2\end{array}$ & $\begin{array}{l}100 \\
100\end{array}$ \\
\hline South Korea & $\begin{array}{l}1991 \\
2001\end{array}$ & $\begin{array}{l}18 \\
32\end{array}$ & $\begin{array}{l}23 \\
10\end{array}$ & $\begin{array}{l}12 \\
14\end{array}$ & $\begin{array}{l}0 \\
0\end{array}$ & $\begin{array}{l}0 \\
0\end{array}$ & $\begin{array}{l}11 \\
10\end{array}$ & $\begin{array}{l}36 \\
33\end{array}$ & $\begin{array}{l}0 \\
0\end{array}$ & $\begin{array}{l}100 \\
100\end{array}$ \\
\hline Taiwan & $\begin{array}{l}1991 \\
2001\end{array}$ & $\begin{array}{l}26 \\
31\end{array}$ & $\begin{array}{l}28 \\
14\end{array}$ & $\begin{array}{r}4 \\
23\end{array}$ & $\begin{array}{l}0 \\
0\end{array}$ & $\begin{array}{l}0 \\
0\end{array}$ & $\begin{array}{l}14 \\
13\end{array}$ & $\begin{array}{l}28 \\
19\end{array}$ & $\begin{array}{l}0 \\
0\end{array}$ & $\begin{array}{l}100 \\
100\end{array}$ \\
\hline Thailand & $\begin{array}{l}1991 \\
2001\end{array}$ & $\begin{array}{l}22 \\
23\end{array}$ & $\begin{array}{l}5 \\
7\end{array}$ & $\begin{array}{l}21 \\
19\end{array}$ & $\begin{array}{r}0 \\
18\end{array}$ & $\begin{array}{l}27 \\
17\end{array}$ & $\begin{array}{l}25 \\
16\end{array}$ & $\begin{array}{l}0 \\
0\end{array}$ & $\begin{array}{l}0 \\
0\end{array}$ & $\begin{array}{l}100 \\
100\end{array}$ \\
\hline Philippines & $\begin{array}{l}1991 \\
2000\end{array}$ & $\begin{array}{c}6 \\
24\end{array}$ & $\begin{array}{l}49 \\
36\end{array}$ & $\begin{array}{l}0 \\
0\end{array}$ & $\begin{array}{l}0 \\
0\end{array}$ & $\begin{array}{l}0 \\
0\end{array}$ & $\begin{array}{l}32 \\
21\end{array}$ & $\begin{array}{l}0 \\
?\end{array}$ & $\begin{array}{l}13 \\
21\end{array}$ & $\begin{array}{l}100 \\
100\end{array}$ \\
\hline Mexico & $\begin{array}{l}1991 \\
2000\end{array}$ & $\begin{array}{l}4 \\
6\end{array}$ & $\begin{array}{l}0 \\
0\end{array}$ & $\begin{array}{l}0 \\
0\end{array}$ & $\begin{array}{r}0 \\
13\end{array}$ & $\begin{array}{l}61 \\
49\end{array}$ & $\begin{array}{l}29 \\
25\end{array}$ & $\begin{array}{l}3 \\
3\end{array}$ & $\begin{array}{l}3 \\
3\end{array}$ & $\begin{array}{l}100 \\
100\end{array}$ \\
\hline Argentina & $\begin{array}{l}1990 \\
2000 \\
\end{array}$ & $\begin{array}{c}1 \\
<1 \\
\end{array}$ & $\begin{array}{l}20 \\
14 \\
\end{array}$ & $\begin{array}{l}0 \\
4 \\
\end{array}$ & $\begin{array}{l}0 \\
0 \\
\end{array}$ & $\begin{array}{l}30 \\
20 \\
\end{array}$ & $\begin{array}{l}43 \\
52 \\
\end{array}$ & $\begin{array}{l}7 \\
9 \\
\end{array}$ & $\begin{array}{l}0 \\
0 \\
\end{array}$ & $\begin{array}{l}100 \\
100 \\
\end{array}$ \\
\hline
\end{tabular}

China: Some part of the year 2000 coal total is likely to be oil and/or gas. Capacity may include large self-producers. India: Coal total includes a small amount of diesel. Years refer to fiscal year. Indonesia: 2001 values are for the moderate scenario. Years refer to fiscal year. Philippines: Mothballed nuclear plant may come on line; not included in the total. Argentina: Vle estimated year-2000 values based on unofficial scenarios. 
While a decade ago many developing nations, particularly those without indigenous energy resources, viewed nuclear power as a promising option, the long-term plans from these nine countries reflect a more limited role for nuclear generation in the future. The high capital costs of nuclear power relative to other generating sources have served to make it less attractive, as has public opposition to nuclear power. Nonetheless, nuclear power registers a significant increase in South Korea and China, which plan to add $8 \mathrm{GW}$ and $6 \mathrm{GW}$ of nuclear capacity respectively. Taiwan plans to add $2 \mathrm{GW}$ of nuclear capacity despite a fair amount of opposition. India plans to add $1.2 \mathrm{GW}$ (through 1997), but the high cost of nuclear power is becoming more of an issue. Argentina may complete a 745-MW nuclear plant under construction if funds can be found, while the Philippines may bring the closed Bataan reactor on line if agreement can be reached with the supplier regarding plant rehabilitation. Both Thailand and Indonesia are examining the possibilities of developing nuclear power over the longer term.

Hydro capacity is expected to expand in every country, but in most cases, the absolute growth is modest. Many countries already have made use of much of their easily exploitable hydro capacity and others face growing opposition to large-scale hydro facilities, which often entail the flooding of large areas and the relocation of substantial populations. The high capital costs of hydro facilities serve as another deterrent. The largest expansion in hydropower capacity is expected in China (around $40 \mathrm{GW}$, including the initial parts of the massive Three Gorges project). In Argentina, new hydroelectric facilities account for three-quarters of the increase in capacity between 1991 and 2000. Despite the absolute growth, the share of hydro in the mix declines in most of the other countries. (The bulk of the new hydro capacity in Taiwan and South Korea will be for pumped storage projects.)

Geothermal energy is due to be an important source of electricity in the Philippines and will play a small role in Indonesia and Mexico.

The shares of electricity generation and the corresponding amounts of fuel consumption are and will be somewhat different from the shares of installed capacity. The extent of this phenomenon varies among countries. The shares of installed hydro capacity that are actually used vary seasonally and annually depending on rainfall, reservoir storage capacity and the role of the hydro plants in the power system. Since power plants that are operated as base load facilities account for a greater share of total generation than those used to meet peak loads, electricity generation from coal, oil/gas steam and nuclear power plants will typically be more significant than indicated by their respective shares of installed capacity.

\subsection{Key Issues Affecting the Plans}

The projected expansions translate into growth rates comparable to those recorded in the 1980s in most of the countries, which suggests that the planned growth is technically feasible. (Only in the Philippines, where past growth was quite low and the plans are rather optimistic, are projected growth rates significantly higher than in the past.) In practice, however, financial, institutional and environmental constraints may make it difficult for many of the countries to achieve the planned growth. 
Past plans for expanding the power sector in developing countries often have proved to be somewhat (and sometimes very) optimistic. More than likely, some of these countries will not witness all of the planned growth in generating capacity within the time frame under consideration. In addition to the more predictable barriers, unforeseen internal and external events will shape the future course of power system expansion. The growing role of market forces also may lead to deviations from the official plans.

Financial Issues. The plans for the power sector will be most easily achieved in the more industrialized countries of Asia (South Korea, Taiwan), where the financial situation of the power sector is relatively sound, and in those countries where the prospects for power sector investment are relatively good (China, Thailand). Many utilities face problems in raising capital, especially in India, Indonesia, the Philippines, Mexico and Argentina. In the more conservative lending environment of the 1990s (caused in part by the poor financial performance of many developing country utilities), shortage of capital has become increasingly influential in shaping developing country plans for the power sector.

Lack of capital is likely to affect the expansion of hydro and nuclear power capacity, both of which are characterized by low operating costs, but high capital costs. In many of the countries, the combination of financial barriers and growing opposition to hydro and nuclear on environmental/social grounds could lead to significant alterations in the plans. Those countries which have access to relatively inexpensive natural gas supplies are likely to rely more heavily on combined-cycle gas turbines, which offer low first costs and high efficiency.

The relatively stable prices of fuels in the international market and the general trend toward less regulated and more open economies have created a growing readiness among developing countries to rely on imported fuels to meet rising electricity demand. The dominance of imported-coal plants and the growing role of LNG in the long-term plans reflect this willingness. At the same time, many countries suffer from foreign exchange shortages, which limit their ability to import fuels for the power industry.

Private Sector Participation. In many of the countries, the shortage of capital has led to strong interest in private sector participation in electricity generation. In some cases, the planned expansion will not occur without considerable investment from the private sector (domestic and foreign). Argentina is in the process of privatizing most of its power sector. Indonesia and the Philippines plan to rely heavily on private investment in the future through Build-Operate-Transfer arrangements. India recently created new incentives for private sector participation. China and Mexico also hope to attract more private capital.

Private sector investors are likely to have a great bias towards projects with low capital costs, due to the higher cost of private investors' capital and their desire to minimize risk. The goal of private investors to minimize construction times and secure a reliable fuel supply may lead to greater use of oil-fired gas turbines. While private power has enormous potential, the rate of its expansion will depend on the terms that governments are willing to provide, as well as on the degree of risk that investors are willing to accept. 
Efficiency Improvement. In contrast to the industrialized countries, most developing countries could substantially improve the efficiency of their electricity generation, transmission and distribution. Many investments in this area have quick paybacks. Implementing proper maintenance programs and rationalizing operations can also yield major efficiency gains and allow for better service. Improvements in load management to reduce or shift peak demand also would result in more efficient use of the utility system.

An increasing number of studies indicate that improving end-use efficiency can prove less costly than expanding the electricity supply. ${ }^{2}$ The removal of electricity price subsidies will increase interest in more efficient and careful use of electricity (and also improve the financial well-being of utilities). Many countries have already taken substantial steps in this direction. However, the strong bias against higher first-cost technologies in developing countries may serve as a major barrier against improving efficiency in the absence of strong government policies and complementary utility programs. The extent to which utilities and governments will take strong steps in the areas of pricing reform, demand-side management (DSM) and other end-use efficiency policies remains a key area of uncertainty.

The success of efforts aimed at improving end-use efficiency will depend on the ability of utilities to envision a change in their traditional roles. The implementation of such programs will also require greater financial and technical assistance from multilateral lending institutions and development assistance agencies. Among the countries in this study, only Thailand has committed itself to a comprehensive DSM program patterned after programs that have met with success in the United States. Other countries have shown signs of interest and several governments have begun implementing policies that require minimum efficiency levels in new equipment and buildings. The World Bank recently signalled its readiness to play a larger role in providing assistance to projects aimed at improving end-use efficiency. ${ }^{3}$

Local and Regional Environmental Issues. In all of the countries, environmental factors may cause delays in or even cancellation of planned power projects. The environmental movement has gained momentum in almost all of these countries. As a result, siting new thermal and hydroelectric power plants has emerged as a major challenge. In most of the nine countries, the long-term power development plans include hydro projects that are the source of controversy and could meet with substantial opposition.

The power development plans suggest considerable increases in both the share and the absolute magnitude of coal use for power generation, especially in Asia. The plans in China alone indicate a near doubling in coal use in the power sector between 1990 and 2000 . While the local and regional environmental problems associated with the growing use of coal will lead to more stringent control of particulate, $\mathrm{SO}_{2}$ and $\mathrm{NO}_{2}$ emissions from coal-fired plants and other

\footnotetext{
${ }^{2}$ For an overview, see: Levine, M., et al., Electricity End-Use Efficiency: Experience with Technologies, Markets, and Policies throughout the World, Lawrence Berkeley Laboratory, Berkeley, CA, 1993.

${ }^{3}$ World Bank, Energy Efficiency and Conservation in the Developing World: The World Bank's Role, September 1992.
} 
mitigation measures, environmental factors alone are unlikely to cause a shift from coal to other fuels.

To the extent that the goal of liniting emissions from new coal-fired plants becomes important (thereby increasing the capital costs), some of these countries could face capital constraints building their planned coal facilities. In China and India, the largest and most coal-reliant of the countries, problems with the transport of domestic coal could lead utilities to favor other fuels. However, because most other fuels would have to be imported, coal is likely to continue to prove the most attractive option.

In the wealthier countries, particularly Taiwan and South Korea, the environmental constraints of coal use have already contributed to an increase in the use of LNG and nuclear power. Indonesia, Thailand and the Philippines are likely to be faced with similar decisions in the near future.

Global Warming Considerations. Developing countries are not expected to give the same degree of attention to limiting carbon dioxide emissions as their industrialized neighbors. However, the long-term outlook suggests that the growth of the developing world power sector is likely to spur a considerable increase in emissions of greenhouse gases.

While there is still much potential to develop hydroelectric resources and nuclear power has its backers, the high capital cost of and public opposition to these zero- $\mathrm{CO}_{2}$ options may well constrain their ability to displace coal in the power mix. The most attractive conventional option is natural gas. Given the efficiency of gas use in combined-cycle power plants, the relative emissions of $\mathrm{CO}_{2}$ per $\mathrm{kWh}$ of electricity are even lower than the actual carbon content of gas would suggest. Still, the widespread use of gas is constrained by the lack of infrastructure to exploit and transport domestic supplies. In addition, LNG imports are an expensive option for most countries.

Solar, wind, biomass and mini-hydro electricity technologies have been hailed as low-impact (and zero- $\mathrm{CO}_{2}$ ) options by their supporters and dismissed as insignificant, unreliable, or too expensive by their detractors. In truth, it is difficult to generalize among these diverse technologies, as their economic viability and practicality is highly site-specific. The currently high capital costs of many renewable technologies serve as a barrier to their widespread use in LDCs. However, the use of renewables is in fact growing (largely as a result of favorable terms offered by Western countries seeking export markets). Many of the decentralized renewable technologies offer cost-effective options for serving remote areas relative to the costs of extending the grid. A recent study sponsored by the United Nations found that the costs of many renewable technologies could be reduced considerably. ${ }^{4}$ This finding implies that renewables could play a much larger role than is envisioned in conventional projections.

\footnotetext{
4 Johansson, J.B., H. Kelly, A.K. Reddy, and R.H. Williams, Fuels and Electricity from Renewable Sources of Energy, Washington, DC: Island Press, 1992.
} 
Improvements in supply and end-use efficiency could prove a less expensive option for restraining $\mathrm{CO}_{2}$ emissions (and other environmental impacts) than expanding the role of any of the alternative generating technologies. On the demand side, many improvements will occur as countries open their industries to more competition and move toward marginal-cost pricing. But many barriers to fully realizing this efficiency potential are likely to emerge. Without a doubt, there is great scope for increased activity and assistance in this area, especially in avoiding lost opportunities as new equipment and buildings enter the stocks.

\subsection{Conclusion: The Need for an Integrated Approach to Planning}

Power sector planners in the developing countries are facing both an increasing array of options and rising constraints. Along with traditional decisions regarding the optimum mix of generating technologies, utility planners now must decide how best to integrate non-utility generation into their plans and how much emphasis to place on demand-side management. Governments must formulate policies on electricity price reforms, the role of private sector participation in the power sector (as well as possible privatization of utilities), major electricityrelated environmental issues and end-use efficiency regulations and incentives.

To assure the best use of limited resources, power sector planning requires an integrated approach which allows the various options to be considered in a common (and comprehensive) framework. Such an approach in turn requires much better information than presently exists on the array of options, especially on the demand side, as well as on environmental impacts on the supply side. This approach also calls for the use of planning techniques that are not well-known in the developing world. While implementing the integration of resource planning into the power sector will present utilities and governments with new challenges, it will also leave them better able to shape a future that meets their goals for sustainable economic and social development. 

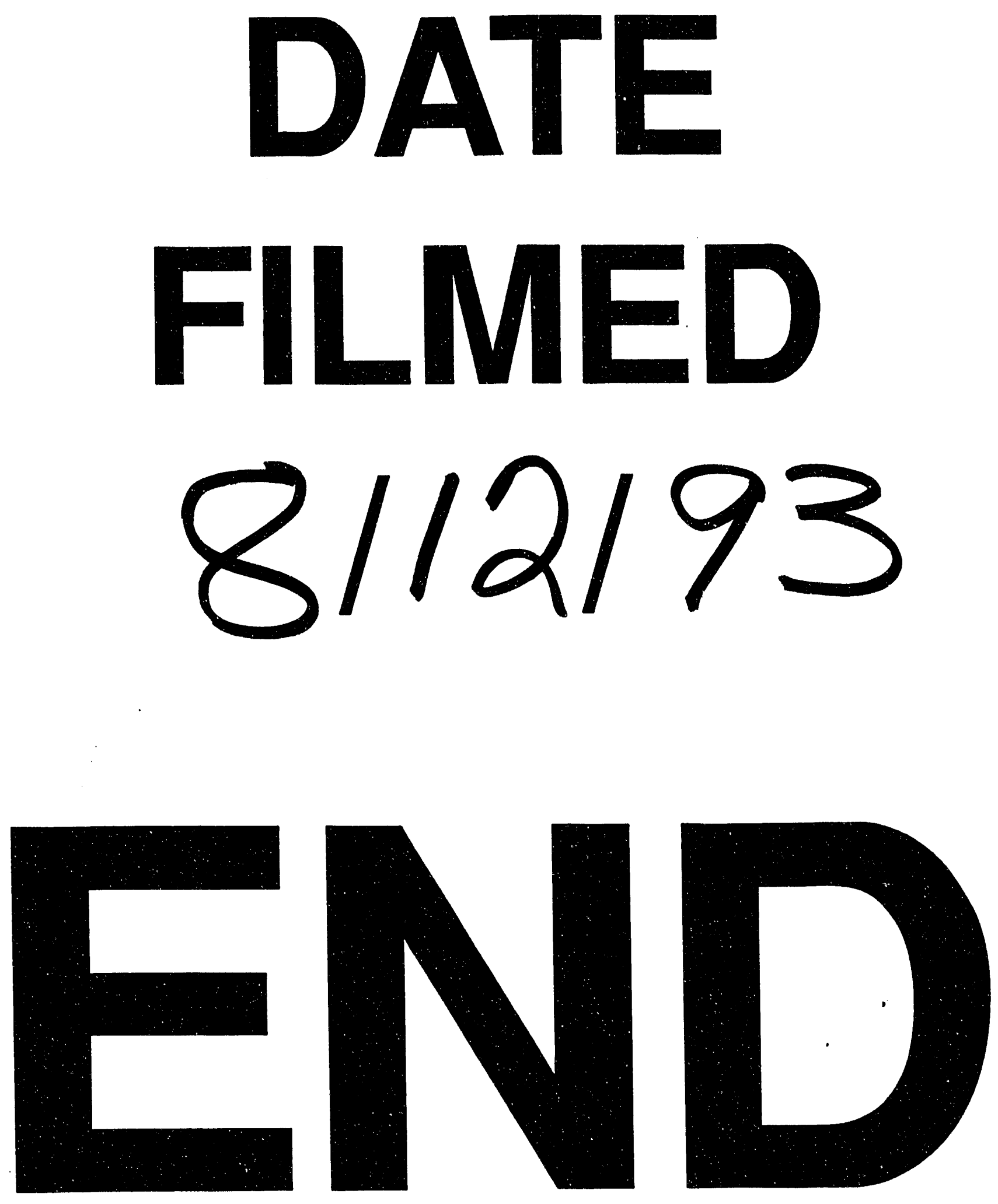
